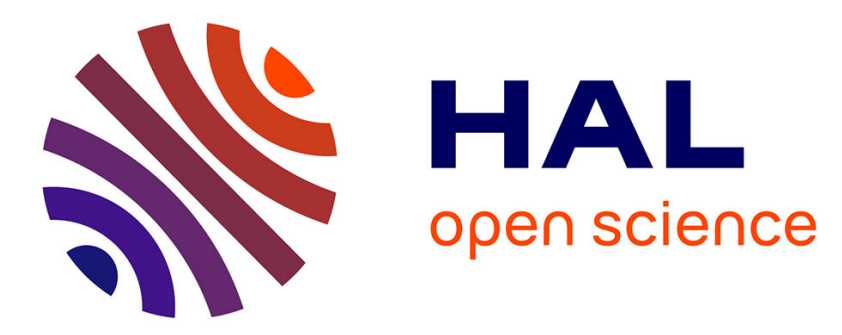

\title{
Proton shuttle mechanism in the transition state of lipase catalyzed N-acylation of amino alcohols
}

Per-Olof Syren, Florian Le Joubioux, Yesmine Ben Henda, Thierry Maugard, Karl Hult, Marianne Graber

\section{- To cite this version:}

Per-Olof Syren, Florian Le Joubioux, Yesmine Ben Henda, Thierry Maugard, Karl Hult, et al.. Proton shuttle mechanism in the transition state of lipase catalyzed N-acylation of amino alcohols. ChemCatChem, 2013, 5, pp.1842-1853. 10.1002/cctc.201200751 . hal-01070389

\author{
HAL Id: hal-01070389 \\ https://hal.science/hal-01070389
}

Submitted on 1 Oct 2014

HAL is a multi-disciplinary open access archive for the deposit and dissemination of scientific research documents, whether they are published or not. The documents may come from teaching and research institutions in France or abroad, or from public or private research centers.
L'archive ouverte pluridisciplinaire HAL, est destinée au dépôt et à la diffusion de documents scientifiques de niveau recherche, publiés ou non, émanant des établissements d'enseignement et de recherche français ou étrangers, des laboratoires publics ou privés. 


\title{
Proton shuttle mechanism in the transition state of lipase catalyzed $\mathbf{N}$-acylation of amino alcohols
}

\author{
Per-Olof Syrén ${ }^{* a],[c]}$, Florian Le Joubioux ${ }^{[b]}$, Yesmine Ben Henda ${ }^{[b]}$, Thierry \\ Maugard $^{[b]}$, Karl Hult ${ }^{[c]}$, Marianne Graber ${ }^{*[b]}$
}

Dedication ((optional))

An increased reaction rate for lipase catalyzed $\mathrm{N}$-acylation of amino alcohols compared to monofunctionalized amines can be explained by a hydrogen shuffling mechanism that avoids nitrogen inversion in the transition state. The mechanism does not involve acyl migration from an ester intermediate which would be formed first, an explanation that permeates the literature. Our suggested reaction mechanism is dependent on the preference of amino alcohols to form intramolecular hydrogen bonds and the capability of the enzyme to accommodate and exploit the specific hydrogen bonding pattern provided by the ligand during catalysis. Our proposed proton shuttle mechanism involves the transfer of two protons in the transition state concomitant with nucleophilic attack on the acyl enzyme and provides

\section{Introduction}

Amino alcohols are used as chiral auxiliaries and chiral ligands in a plethora of asymmetric transformations. ${ }^{[1]}$ The fully reduced equivalent of amino acids, 1,2-amino alcohols, have received most of the attention. ${ }^{[2]}$ Moreover, amino alcohols constitute important compounds in the pharmaceutical, agrochemical, cosmetic and beauty industries ${ }^{[3]}$ and they are readily available from a vast source of precursor molecules including amino acids, imines, epoxides and isoxazolines. ${ }^{[4]}$ Besides being important molecules in synthetic chemistry, amino alcohols and derivatives thereof including sphingosine ( $(2 S, 3 R, 4 E)$-2-amino-octadec-4ene-1,3-diol), ceramide and the sphingolipids are crucial for the cell as mediators of signalling cascades. ${ }^{[5]}$ Therefore expanding our understanding on how amino alcohols function at the molecular level is of significant importance. Herein we propose a new reaction mechanism for lipase catalyzed $N$-acylation of amino alcohols and related compounds in which the enzyme is able to exploit a specific hydrogen bonding pattern, provided by the ligand, for catalysis by proton shuttling in the transition state (TS). The proton shuttling is mediated by the two functional groups present in the amino alcohol (or in the related difunctionalized amine substrate) linked together by an intramolecular hydrogen bond and by the availability of a suitable base to act as proton acceptor in the enzyme active site. Our suggested proton shuttle mechanism is thus not limited to the $\alpha, \beta$ - an explanation to the high reaction rate and chemoselectivity for lipase catalyzed $\mathrm{N}$-acylation of amino alcohols. Moreover the proton shuttle mechanism explains the increased reaction rate for the enzyme catalyzed $\mathrm{N}$-acylation of diamines and of methoxy-2propylamine for which $\mathrm{O}$ - to $\mathrm{N}$-acyl migration is impossible. A Linear Free Energy Relationship (LFER) analysis based on the experimental results showed that all of our investigated difunctionalized amine substrates afforded a substrate assisted rate acceleration of $\mathrm{N}$ acylation by the same reaction mechanism. Furthermore the LFER analysis was consistent with partial proton transfer in the rate limiting transition state which further supports our suggested proton shuttle mechanism.

hydrolase fold. The fact that amino alcohols can participate in such concerted proton shuffling using a suitable base in an enzyme scaffold constitutes an interesting inherent property of amino alcohols that to our best knowledge was previously not known.

Transacylation reactions involving amino alcohols have recently gained attention. ${ }^{[6]}$ In acylation reactions of amino alcohols, the alcohol and amino groups have different reactivities. It has been found that 1,2-amino alcohols react to give the $N$ acylated product in water in the absence of catalyst through a suggested mechanism that involves intramolecular general base

[a] Dr.P.-O. Syrén

Present address:

Institute of Technical Biochemistry

University of Stuttgart

Allmandring 31, D-70569 Stuttgart, Germany

Fax: (+49)-(0)711-685-63196

E-mail:per-olof.syren@itb.uni-stuttgart.de

[b] Prof. M. Graber, F. Le Joubioux, Y. Ben Henda, Prof. T. Maugard UMR CNRS 7266 LIENSS

Université de La Rochelle,

Bâtiment Marie Curie, Avenue Michel Crépeau 17042 La Rochelle cedex 1, France

E-mail: mgraber@univ-Ir.fr

[c] Prof. K. Hult

Department of Biochemistry

School of Biotechnology

Royal Institute of Technology (KTH)

AlbaNova University Centre

SE-106 91 Stockholm, Sweden 
catalysis followed by $\mathrm{O}$ - to $\mathrm{N}$-acyl migration. ${ }^{[7]}$ It is interesting to note that the reaction rate for the uncatalyzed acylation of amino alcohols is higher than expected based on nitrogen basicity solely indicative of cooperation between the nitrogen and the oxygen atoms in the reaction mechanism. ${ }^{[7-8]}$ In chemical acylation of amino alcohols, the $\mathrm{N}, \mathrm{O}$-diacylated product is observed ${ }^{[9]}$ although the chemoselectivity can be significantly enhanced in favor of $O$-acylation by using tertiary amino alcohols ${ }^{[10]}$ or a tetranuclear zinc cluster as catalyst. ${ }^{[11]}$ Recently focus has been on using enzymes as catalysts for the chemoselective acylation of amino alcohols. ${ }^{[12]}$ Interestingly the selectivity in enzyme catalyzed acylation of amino alcohols is the opposite to the selectivity obtained using metal catalysis. ${ }^{[6,}{ }^{11]}$ It has been suggested that the lipase catalyzed chemoselective $N$-acylation of 1,2-amino alcohols proceeds through initial $O$-acylation followed by spontaneous $\mathrm{O}$ - to $\mathrm{N}$-acyl migration. ${ }^{[13]}$ Herein we report experimental results on the lipase catalyzed acylation of amino alcohols and related compounds that are not in accordance with that hypothesis of acyl migration as an explanation of the observed chemoselectivity and rate enhancement for $\mathrm{N}$-acylation. Furthermore by using density functional theory (DFT) calculations at the B3LYP/6-31G(d,p) level using an active site model containing 205 atoms and MDsimulations we identified a previously unknown reaction mechanism in which the enzyme is able to take advantage of an intramolecular hydrogen bond of the amino alcohol substrate during catalysis. Our proposed mechanism involves a concerted nucleophilic attack by the lone pair of the nitrogen on the acyl enzyme concomitant with an intramolecular proton transfer from the nitrogen and the transfer of the hydroxyl proton of the amino alcohol to the enzyme catalytic base. This proton shuttling in the TS in the enzyme active site leads to the formation of a stereoelectronically favorable intermediate for facile amide bond synthesis (Scheme 1). Moreover our proposed proton shuttle mechanism explains the rate enhancement for the enzyme catalyzed $\mathrm{N}$-acylation of other difunctionalized amines including methoxy-2-propylamine and diamines for which $\mathrm{O}$ - to $\mathrm{N}$-acyl migration is not applicable.
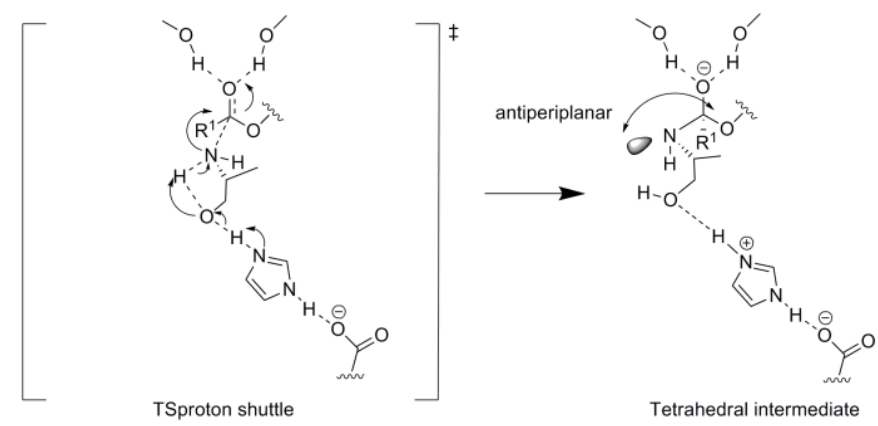

Scheme 1. Proposed proton shuttle reaction mechanism in TS (labelled TS $S_{\text {proton }}$ shuttle) for lipase catalyzed $\mathrm{N}$-acylation of amino alcohols which leads to the formation of a tetrahedral intermediate in a stereoelectronically favourable ${ }^{[14]}$ conformation for amide bond synthesis without the need for nitrogen inversion. Our suggested reaction mechanism is shown using $(R)$-alaninol as substrate. Note that the proton shuttle mechanism works in the same way for diamines where a nitrogen replaces the oxygen as the substrate assisted acceptor.

\section{Results and Discussion}

The enzyme catalyzed acylation of amino alcohols (1a-d) is outlined in Scheme 2. Three different types of acylated products are possible: the $\mathrm{O}$-acylated amino alcohol (2a-d), the $\mathrm{N}$-acylated

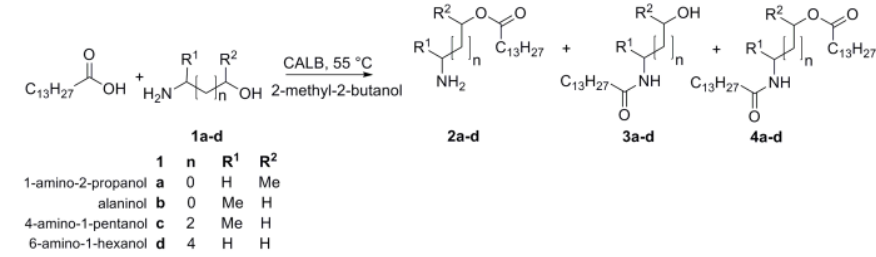

Scheme 2. Acylation of amino alcohols catalyzed by Candida antarctica lipase $\mathrm{B}$ (CALB, EC 3.1.1.3) using myristic acid as acyl donor.

amino alcohol (3a-d) and the diacylated amino alcohol (4a-d). For comparison, the substrate scope was extended by analyzing the lipase catalyzed acylation of a secondary alcohol, a secondary amine, a diol and a diamine. The initial kinetics for lipase catalyzed $\mathrm{N}$-acylation and $\mathrm{O}$-acylation respectively were measured and the resulting apparent $k_{c a t}$ values $\left(k_{c a t, a p p}\right)$ are given in Table 1.

Table 1. Experimentally determined apparent $k_{\text {cat }}$ values for $\mathrm{N}$-acylation and $\mathrm{O}$ acylation using Candida antarctica lipase B in 2-methyl-2-butanol as solvent at $55^{\circ} \mathrm{C}$. Myristic acid was used as acyl donor.

$\begin{array}{lll}\text { Substrate }^{[\mathrm{a}]} & N- & O- \\ & \text { acylation } & \text { acylation } \\ & k_{\text {cat,app }} & k_{c a t, a p p} \\ & {\left[\mathrm{~min}^{-1}\right]} & {\left[\mathrm{min}^{-1}\right]}\end{array}$

acylation of amino alcohols<smiles>CC(N)CCCCCCOCC(C)N</smiles>

acylation of a monofunctional group

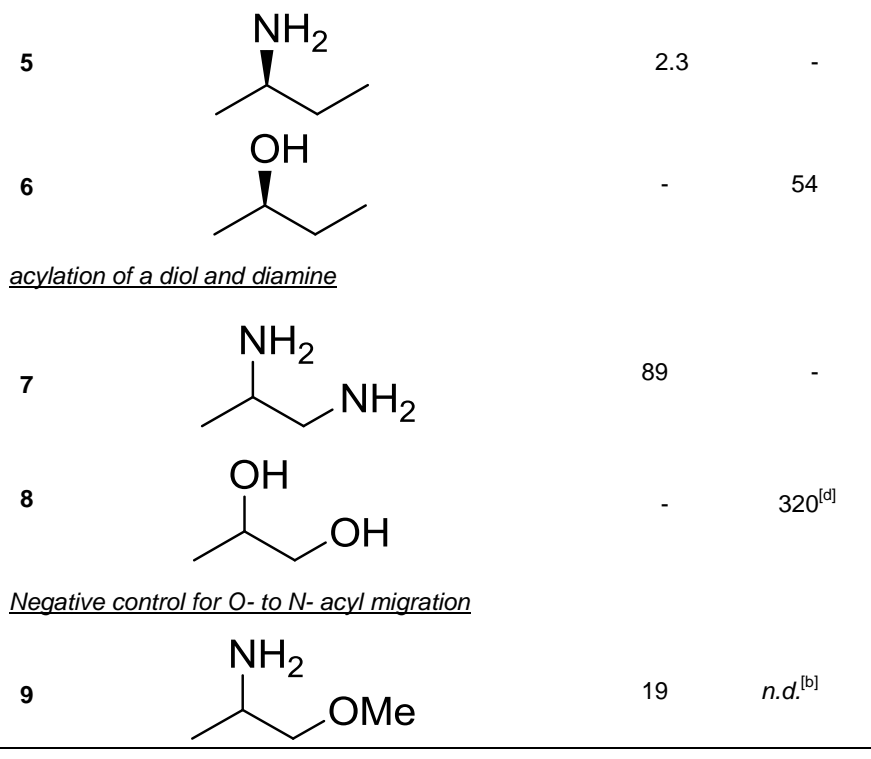

[a] The pure $(R$ )-enantiomer of 2-butanol (6) and 2-butylamine (5) was used, respectively [b] The $O$-monoacylated product was not detected. [c] Trace amounts of the $\mathrm{N}, \mathrm{O}$-diacylated product were detected, formed at a $k_{\text {cat,app }}$ tenfold lower than the $k_{\text {cat,app }}$ value for $\mathrm{N}$-acylation [d] $k_{\text {cat,app }}$ for $O$-acylation of the primary hydroxyl group was $260 \mathrm{~min}^{-1}$ and $k_{\text {cat,app }}$ for $O$-acylation of the secondary hydroxyl group was $60 \mathrm{~min}^{-1}$ 
The enzyme catalyzed acylation of amino alcohols (1a and $\mathbf{1 b}$ ) was compared with the acylation of monofunctional substrates (Table 1, substrate 5 and 6). The apparent $k_{\text {cat }}$ for $N$-acylation using $(R)$-2-butylamine (5) as nucleophile was found to be 25 fold lower than the apparent $k_{\text {cat }}$ value for $O$-acylation using $(R)$-2butanol (6), in contrast with the intrinsic chemical reactivities of these two functional groups ${ }^{[15]}$ but in accordance with the well known fact that lipases and esterases are very poor catalysts in the hydrolysis and synthesis of amide bonds. ${ }^{[16]}$

For the homo difunctionalized substrate 1,2-diaminopropane (7) the apparent $k_{\text {cat }}$ value for $N$-acylation was found to be the highest of the investigated substrates (40 times higher compared to the value for $(R)$-2-butylamine (5)) and only fourfold lower than the rate constant for $O$-acylation of 1,2-propanediol (8). The enhanced apparent $k_{\text {cat }}$ for $N$-acylation displayed by 1,2 diaminopropane can not be explained by enhanced nucleophilicity ${ }^{[17]}$ and indicates a cooperative interaction between the two amino groups facilitating $N$-acylation in the enzyme active site. Such cooperative interaction was not observed for 1,2propanediol (8) for which the primary hydroxyl did not assist in the $O$-acylation of the secondary hydroxyl. Moreover the hydroxyl group present in the investigated amino alcohols leads to an increased $k_{\text {cat }}$ value for $\mathrm{N}$-acylation of 5 to 25 times compared to the value for $(R)$-2-butylamine (5).

In the literature, the observed rate increase and chemoselectivity for lipase catalyzed $\mathrm{N}$-acylation of amino alcohols has been attributed to initial $\mathrm{O}$-acylation followed by $\mathrm{O}$ to $N$-acyl migration. ${ }^{[13,}{ }^{18]}$ Acyl migrations are well known phenomena in chemistry and are used for converting prodrugs with beneficial properties such as increased solubility, to their corresponding parent molecules. ${ }^{[19]}$ However, we did not observe any $O$-acylated intermediate of the amino alcohols or of methoxy2-propylamine (9) from which the presumed $O$ - to $\mathrm{N}$-acyl migration would occur (the experimental detection limit was $2 \mu \mathrm{M}$, see Supporting Information). Such $\mathrm{O}$ - to $\mathrm{N}$-acyl migration would need to proceed faster than the enzyme catalyzed reaction in order for the $\mathrm{O}$-acylated intermediate to remain undetected. Acyl migrations between two oxygens in glucose and in a glyceride have been reported to occur at a rate of $0.005 \mathrm{~min}^{-1}$ and 0.002 $\mathrm{min}^{-1}$ respectively. ${ }^{[20]}$ Acid catalyzed $\mathrm{N}$ - to $\mathrm{O}$-acyl migrations in phosphopeptides have been studied ${ }^{[21]}$ and the reported conversions correspond to an acyl migration rate of $0.002 \mathrm{~min}^{-1}$. The $O$ - to $N$-acyl migration in ethanol amine was found to proceed with rates much lower than $1 \mathrm{~min}^{-1} .^{[22]}$ In a study of the acyl migration in $O$-arachidonoylethanolamine and $O$ palmitoylethanolamine the published data corresponded roughly to a base promoted $O$ - to $N$ - acyl migration rate of less than 0.02 $\mathrm{min}^{-1} .{ }^{[23]}$ The experimentally determined reaction rates for base catalyzed $\mathrm{O}$ - to $\mathrm{N}$-acyl migrations are at least one to two orders of magnitude slower than our experimentally determined reaction rates for enzyme catalyzed acylation of amino alcohols. Since the acyl donor myristic acid was used in slight excess in our experiments, an acid catalyzed $\mathrm{N}$ - to $\mathrm{O}$ - acyl migration would be more likely than the corresponding $\mathrm{O}$ - to $\mathrm{N}$ - transfer. $^{[23]}$ If $\mathrm{O}$ - to $\mathrm{N}$ acyl migration would play a major role for lipase catalyzed $N$ acylation of amino alcohols, the $\mathrm{O}$-acylated intermediate would build up and reach a steady-state concentration. Under our experimental conditions the steady-state concentration of this intermediate would reach 1-100 mM (Supporting Information). No $O$-acylated intermediate was found despite that our detection limit was $2 \mu \mathrm{M}$. To further confirm the fact that acyl migrations can not explain our experimental results, we performed an enzyme catalyzed acylation of methoxy-2-propylamine (9, Table 1$)$ with a poor nucleophilic oxygen which lacks the capability of $\mathrm{O}$ - to $\mathrm{N}$ acyl migration. The apparent $k_{\text {cat }}$ value for $N$-acylation of methoxy-2-propylamine was found to be tenfold higher than for $(R)$-2-butylamine (5) and only twofold lower than the corresponding value for alaninol (1b). This is in sharp contrast to chemical $\mathrm{N}$-acylation as well as to metal catalysis where it has been found that methylation of the oxygen atom in the amino alcohol molecule leads to a decrease in reaction rate of two orders of magnitude. ${ }^{[6-8]}$ Furthermore, 1,2-diaminopropane (7) afforded the highest rate acceleration that can not be explained by the acyl migration hypothesis for obvious reasons.

Since an $\mathrm{O}$ - to $\mathrm{N}$-acyl migration could not explain our experimental results we came up with the alternative hypothesis that the additional functional group besides the nitrogen atom ($\mathrm{OH}$ for amino alcohols, $-\mathrm{NH}_{2}$ for the diamine (7) and -OMe for methoxy-2-proylamine (9)) participated in the reaction mechanism and afforded a substrate assisted rate acceleration for $\mathrm{N}$ acylation. The hydroxyl group in amino alcohols promote the formation of intramolecular hydrogen bonds. ${ }^{[24]}$ It has been shown experimentally that ethanol amine exists predominantly in its gauche conformation in solution ${ }^{[25]}$ for which such interactions are facilitated. Two different types of intramolecular hydrogen bonds can exist in amino alcohols (Table 2).

Table 2. Relative distribution of amino alcohol conformers with an intramolecular hydrogen bond based on DFT single-point calculations at the B3LYP/ 6-311+G(2d,2p) level in 2-methyl-2-butanol.

$\begin{array}{ll}\text { Conformer } & \begin{array}{l}\text { Relative energy } \\ {[\mathrm{kcal} / \mathrm{mol}]}\end{array}\end{array}$ Relative abundance $^{[\mathrm{kca}} \quad{ }^{2}$

(R)-Alaninol

$\mathrm{H}$ -<smiles>COC[C@H](C)N</smiles><smiles>C[C@@H]1CO[CH]N1</smiles>

R)-4-Amino-1-pentanol<smiles>C[C@H]1CCCOC1</smiles>

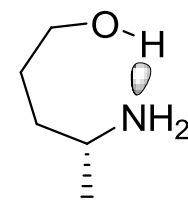

0

0.9993

[a] Using DFT at the B3LYP/6-311+G(2d,2p) level of theory including ZPVE. A Conductor-like Polarizable Continuum Model was used to account for the solvent. Geometry optimizations were performed using B3LYP/6-31G(d,p) level of theory. 
The first set of conformations contains an intramolecular hydrogen bond between one of the amine hydrogens and one of the lone pairs of the oxygen. In the second conformation, the hydroxyl group binds to the lone pair of the nitrogen. We used DFT calculations at the B3LYP/6-311+G(2d,2p) level to assess the relative abundances of substrate conformers containing an intramolecular hydrogen bond for $(R)$-alaninol $(\mathbf{1 b})$ and $(R)$-4amino-1-pentanol (1c) (Table 2). For $(R)$-alaninol, the conformation for which the hydrogen bond is donated by the hydroxyl and accepted by the nitrogen lone pair is slightly preferred in accordance with previously published results on ethanol amine. ${ }^{[26]}$ For the longer amino alcohol, $(R)$-4-amino-1pentanol, only one type of intramolecular hydrogen bond is possible, reflecting an almost perfect - $\mathrm{OH}---\mathrm{N}$ hydrogen bond. Can such substrate conformational distributions be linked to catalysis? It is interesting to note that the major shift in the relative distribution of substrate conformations displayed by the amino alcohol containing a longer chain is accompanied with an enhanced preference for $\mathrm{O}$-acylation (Table 1). We therefore decided to investigate the putative role of an intramolecular hydrogen bond on the reaction mechanism in the enzyme active site that could explain the increased activity for $\mathrm{N}$-acylation for all of the investigated difunctionalized amine substrates.

We have recently discovered a previously unacknowledged hydrogen bond donated by the substrate reacting amide $\mathrm{NH}$ group in the transition state for amide bond hydrolysis of amidases with a spatial arrangement to assist nitrogen inversion in the enzyme active site. ${ }^{[27]}$ The hydrogen bond is important for reaction specificity since esterases that are poor in the hydrolysis/synthesis of an amide bond lack this interaction. ${ }^{[27-28]}$ In order to analyse if such a substrate assisted hydrogen bond donated by the $\mathrm{NH}_{2}$-group of the amino alcohol substrate in the transition state could facilitate enzymatic $N$-acylation, we performed MD-simulations on the acylation of $(R)$-alaninol (1) $)$. From the MD-simulations, in which the tetrahedral intermediate represented the transition state for $\mathrm{N}$-acylation, it was concluded that the reacting $\mathrm{NH}$-group of $(R)$-alaninol did not function as hydrogen bond donor in the modelled transition state. Rather the lone pair of the reacting nitrogen atom accepted a hydrogen bond donated by the hydroxyl (Figure S1, Table S1, Supporting Information). Moreover by using ab initio calculations on $\mathrm{N}$-methyl alaninol we concluded that nitrogen inversion is not facilitated in an amino alcohol compared to an alkyl amine (rather the calculated barrier for inversion was found to be higher for amino alcohols, Table S2, Supporting information). Proton transfer has been discussed in the context of the rate enhancement observed for the chemical catalyzed acylation of diamines. ${ }^{[29]}$ Such proton transfer would be facilitated by the intramolecular hydrogen bonding pattern present in amino alcohols. ${ }^{[30]}$ Interestingly spontaneous proton transfers have been observed in the gasphase in cationic clusters of phenol and ethanol amine. ${ }^{[31]}$ By using $a b$ initio DFT calculations on a small model of a lipase catalytic machinery we found a new alternative mechanism for enzyme catalyzed $\mathrm{N}$-acylation of amino alcohols (Figure S2). In this new, previously undescribed mechanism, the neutral nitrogen atom of the amino alcohol attacks the acyl enzyme coincidently with the transfer of two protons, thus forming a "proton shuttle" (a proton is transferred from the $\mathrm{NH}_{2}$-group to the hydroxyl and at the same time the hydroxyl proton is transferred to the enzyme catalytic base H224). Interestingly, a proton shuttle in the transition state has been suggested to occur for the ribosome via a water molecule ${ }^{[32]}$ and for Mycolic Acid Cyclopropane Synthase involving a bicarbonate. ${ }^{[33]}$ In order to understand the impact on catalysis of our discovered proton shuttle reaction mechanism for $\mathrm{N}$-acylation of amino alcohols, a very large $a b$ initio model of the active site of Candida antarctica lipase B was constructed. It is advantageous to perform calculations in a large model of the active site since such model provides a more realistic reaction environment compared to a small model in the gas-phase. By performing cluster $a b$ initio calculations using this very large model of the active site to simulate the protein environment it is possible to compare the proton shuttle mechanism with the "traditional" reaction mechanism The hypothetical "traditional" mechanism for $\mathrm{N}$-acylation of an amino alcohol is the pathway that would be displayed by a monofunctionalized amine and for which proton shuttling does not occur. Note that the traditional mechanism uses the open chain of the amino alcohol substrate whereas it is known that amino alcohols adopt conformations with an intramolecular hydrogen bond ${ }^{[24]}$ that thus has to be broken to obtain the non-cyclic conformation. Cluster ab initio calculations have previously been used to analyze reaction mechanisms in enzymes. ${ }^{[33-34]}$ Our model of the enzyme active site consisted of 205 atoms and contained 14 amino acids in and around the active site. The geometry of the transition state for $\mathrm{N}$-acylation of $(R)$-alaninol (1) for our suggested proton shuttle reaction mechanism, calculated at B3LYP/6-31G(d,p) level of theory using the large active site model, is shown in Figure 1. The transition state had one imaginary frequency $\left(1030 \mathrm{i} \mathrm{cm} \mathrm{cm}^{-1}\right)$ that corresponded to nucleophilic attack of the nitrogen atom of the amino alcohol on the acyl enzyme coincidently with the transfer of two protons that form the proton shuttle (Figure 1).

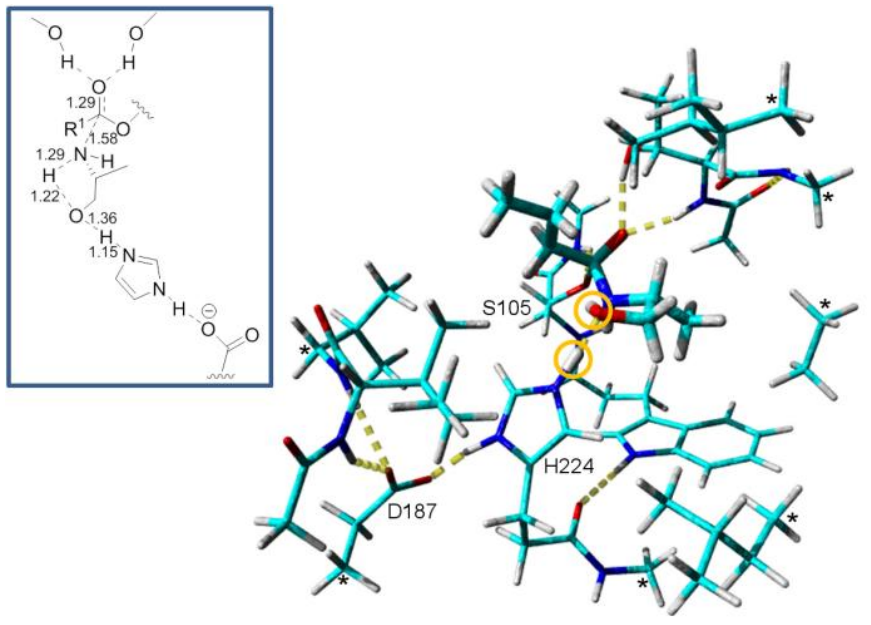

Figure 1. The figure shows the geometry of the transition state for the proposed proton shuttle reaction mechanism obtained at B3LYP/6-31G(d,p) level of theory. A large model of the active site of Candida antarctica lipase B consisting of 205 atoms was used for the cluser ab initio calculations. The scissile nitrogen atom of $(R)$-alaninol is attacking the carbonyl carbon of the acyl enzyme concomitant with the transfer of two protons (encircled). The lengths of the bonds being formed/broken in the transition state are shown in the panel in the top left corner. Atoms marked with an asterisk $\left(^{*}\right)$ were kept fixed during the geometry optimization since the corresponding backbone atoms in the enzyme does not have the ability to move freely. The acyl enzyme with the carbon chain originating from the acyl donor (containing four carbon atoms in our model) and the substrate, $(R)$-alaninol are shown in thick sticks. Color code: Cyan-carbon, Red - oxygen, Blue - nitrogen, White - hydrogen. Hydrogen bonds are indicated with dashed yellow lines. The residues constituting the Ser/His/Asp catalytic triad are labelled. A larger picture of the geometry of the transition state is shown in Figure S3 in Supporting Information. 
The proton shuttle mechanism is facilitated by the preference of amino alcohols to form intramolecular hydrogen bonds and the $(R)$-alaninol (1b) substrate is already preorganized for catalysis in the ES-complex, since it contains the necessary intramolecular hydrogen bond for the "proton shuffling" to occur (Table 2, Row 1). Next, the transition states and intermediates for the hypothetical traditional reaction mechanism for $\mathrm{N}$-acylation of $(R)$ alaninol, for which proton shuttling does not occur, was calculated (Figure S7, for a definition of the different mechanisms discussed, see Supporting Information, Figure S4-S6). For the traditional mechanism of $\mathrm{N}$-acylation, the open chain conformation of $(R)$ alaninol was used, for which proton shuttling can not occur and which would mimic the pathway for a mono substituted amine. The calculated barriers of activation, using the large model of the active site, for $\mathrm{N}$-acylation of $(R)$-alaninol are shown in Figure 2 (with the rate limiting transition states shown, See Also Supporting Information, Figure S7). The nitrogen inversion step for the traditional mechanism ( $\mathrm{TS}_{\text {inv }}$ in Figure 2) was found to be concerted with (and thus part of) amide bond formation at the B3LYP/6-31G(d,p) level of theory (see also supporting information, Figure S4). Using DFT at the B3LYP/6-31G(d,p) level of theory, our proposed reaction mechanism was found to have a barrier of activation that is $1.1 \mathrm{kcal} / \mathrm{mol}$ lower than the barrier for the "traditional" mechanism in the enzyme (the traditional mechanism is outlined in Figure S4). This energy difference corresponds roughly to an increase by a factor of 10 of the rate constant $k_{c a t}$ which is in good agreement with the rate enhancement of enzyme catalyzed $N$-acylation of amino alcohols that we observed experimentally. The calculated barrier for our proposed alternative mechanism $(18.5 \mathrm{kcal} / \mathrm{mol})$ can be translated into a calculated $k_{\text {cat }}$ value of approximately $2 \mathrm{~min}^{-1}$ at $55{ }^{\circ} \mathrm{C}$ using transition state theory, which is in reasonable agreement with the experimentally determined $k_{\text {cat }}$ values for $N$ acylation of amino alcohols (Table 1). Although the calculated energy difference of $1.1 \mathrm{kcal}$ in the very large active site model between our suggested proton shuttle mechanism and the "traditional mechanism" is in accordance with the experimental results (Table 1), it is quite small (it corresponds to a 10 times rate enhancement).

Additional calculations showed that the proton shuttle mechanism works for other substrate assisted acceptors besides a hydroxyl group. We calculated the TS for $\mathrm{N}$-acylation of 1,2diaminoethane (representing 1,2-diaminopropane (7)) by the proton shuttle mechanism (Supporting Information, Figure S8). As for $(R)$-alaninol, nucleophilic attack was concerted with proton shuttling. When constructing the proton shuttle for 1,2diaminoethane in the large active site model of 205 atoms, the barrier was found to be $17.2 \mathrm{kcal} / \mathrm{mol}$ including ZPVE which is 1.3 $\mathrm{kcal} / \mathrm{mol}$ lower than the calculated barrier for $\mathrm{N}$-acylation of $(R)$ alaninol. More importantly the barrier for the proton shuttle mechanism for 1,2-diaminoethane was found to be $5 \mathrm{kcal} / \mathrm{mol}$ lower than the barrier for the traditional mechanism (with nitrogen inversion) thus further corroborating the importance of the proton shuttle and in accordance with our experimental results that 1,2diaminopropane (7) afforded the highest substrate assisted rate acceleration of $\mathrm{N}$-acylation (Table1). MD-simulations of the tetrahedral intermediate representing the transition state for $\mathrm{N}$ acylation of methoxy-2-propylamine (9) showed that the oxygen can accept a proton from the reacting $\mathrm{NH}$-group (Supporting Information, Figure S9). Obviously proton transfer to the enzyme catalytic base occurs in a second step since the methoxylated group lacks a hydrogen. To further corroborate that the proton shuttle mechanism can explain the rate enhancement for enzyme catalyzed $\mathrm{N}$-acylation of all of our investigated substrates, we note that the proton shuttle mechanism involves partial proton transfer in the rate limiting transition state. Therefore, for the proton shuttle mechanism the apparent $k_{\text {cat }}$ value for $\mathrm{N}$-acylation should depend on the $\mathrm{p} K_{a}$ of the substrate as opposed to the "traditional mechanism" for which no partial proton transfer from the reacting $\mathrm{NH}$-group occurs in the rate limiting transition state (nitrogen inversion). A Linear Free Energy Relationship (LFER) analysis showed that the amino alcohols, the diamine and methoxy-2-propylamine (9) afforded a rate acceleration by the same reaction mechanism of $\mathrm{N}$-acylation and the slope of -0.24 was in accordance with partial proton transfer in the transition state (Supporting Information, Figure S10). It should be noted that $(R)$-2-butylamine (5) that lacks the possibility of proton shuffling does not follow the trend observed for the difunctionalized amines and thus operates by a different reaction mechanism of $\mathrm{N}$ acylation (nitrogen inversion).

For the smaller amino alcohols, the rate for enzyme catalyzed $O$ acylation was very low (the $O$-monoacylated intermediate was not detected). We decided to analyze this experimental finding by computing the transition state and intermediates for enzyme catalyzed $O$-acylation starting from the other possible conformation of $(R)$-alaninol that is preorganized for a proton shuttle mechanism with an intramolecular hydrogen bond donated by the hydroxyl (Table 2, second row). As mentioned previously smaller amino alcohols form intramolecular hydrogen bonds $^{[30]}$ and such a ring structure is preorganized to react through a proton shuttle mechanism as described for $\mathrm{N}$-acylation. It was found that the mechanism for $\mathrm{O}$-acylation of $(R)$-alaninol by such proton shuttle (Figure S11) has a much higher barrier compared to $\mathrm{N}$-acylation, clearly demonstrating that the proton shuttle mechanism disfavors $O$-acylation. In our very large model of the active site, the proton shuttle for $\mathrm{O}$-acylation was found to have a barrier that was approximately $20 \mathrm{kcal} / \mathrm{mol}$ higher in energy than for $\mathrm{N}$-acylation based on using a TS-model that was optimized at the B3LYP/6-31G(d,p) level (see Figure S12-S13). This is because of the fact that the remaining free lone pair on the oxygen atom will be close in space to the developing negative charge on the carbonyl oxygen of the acyl enzyme in TS (see Figure S6, S11 and S12 in Supporting Information). The long distance between the nucleophilic oxygen and the carbonyl carbon in the TS for O-acylation that minimizes this electrostatic repulsion results in the catalytic base $\mathrm{H} 224$ no longer being in an optimal position for catalysis, thus disfavoring proton shuffling (Figure S12). Obviously this unfavorable interaction in the TS does not occur for "normal" O-acylation operating on the open chain conformer of the substrate for which the catalytic base (H224) adopts its normal position where a hydrogen bond is formed directly with the substrate nucleophilic hydroxyl group. As noted previously no substrate assisted rate acceleration was observed for 1,2-propanediol (8) (Table 1) in consistence with the fact that the proton shuttle mechanism is highly disfavoured for $O$ acylation. Vicinal diols display a significant relative abundance of substrate conformations that do not contain an intramolecular hydrogen bond ${ }^{[35]}$ and experimental data from the gas phase further shows that the strain energy related to intramolecular hydrogen bond formation is much higher for molecular ions of vicinal diols as compared to corresponding diamines and amino alcohols. ${ }^{[30]}$

The lower barrier of activation for the new proton shuttle mechanism of $\mathrm{N}$-acylation compared to "traditional" $\mathrm{N}$-acylation 


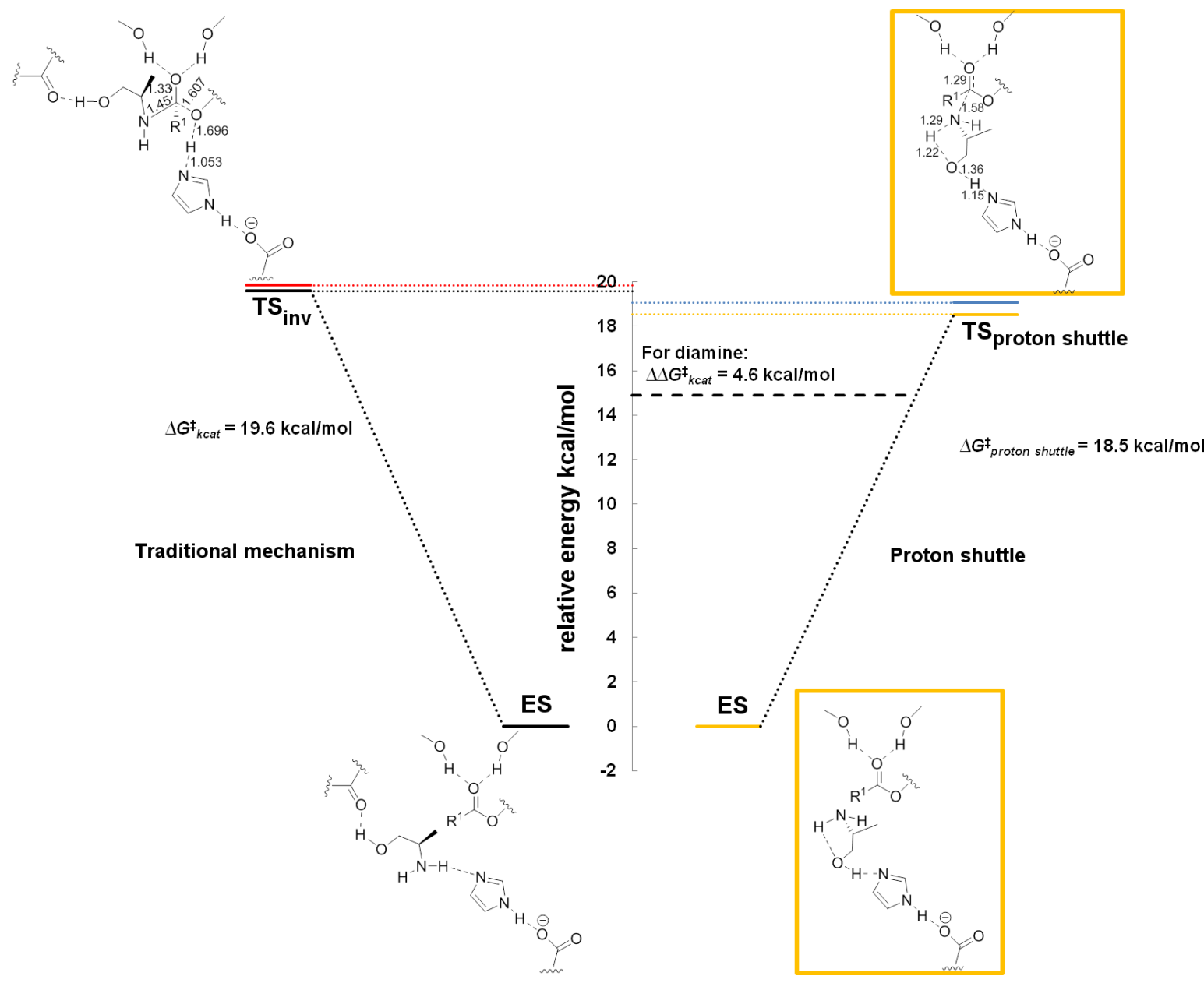

Figure 2. Energy profile diagram for comparison of enzyme catalyzed $N$-acylation of $(R)$-alaninol for the novel proton shuttle mechanism (right) and the hypothetical traditional mechanism that would be the pathway for an amine and for which proton shuttling does not occur (left). The calculated energy difference (4.6 kcal/mol in the gas-phase) in favour of the proton shuttle mechanism over the traditional mechanism for 1,2-diaminoethane (representing 1,2-diaminopropane (7)) is indicated by the bold dashed line. The tetrahedral intermediate produced from the proton shuttle mechanism has the nitrogen lone pair in the stereoelectronically required conformation for amide bond synthesis which makes nitrogen inversion obsolete (see Scheme 1). Note that the hydrogen bond donated by the $(R)$-alaninol substrate hydroxyl and accepted by the backbone of T40 that we used in our model for the hypothetical traditional mechanism (left) replaces the hydrogen bond to the $\mathrm{N}_{\varepsilon 2}$ of the H224 and does not contribute to catalysis since it is fully developed in the ES-complex (the corresponding interaction is formed for the corresponding hypothetical $O$-acylation as well, see also Figure $S 4$, Supporting Information). The $\Delta G^{\ddagger}{ }_{k c a t}$ values given are the calculated activation energies for $N$-acylation of $(R)$ alaninol for the two mechanisms in the gas-phase including ZPVE (orange and black dotted lines respectively, geometry optimizations and vibrational analysis were performed at the B3LYP/6-31G(d,p) level of theory using the large quantum model presented in Figure 1). For the proton shuttle mechanism (right), the ES-complex

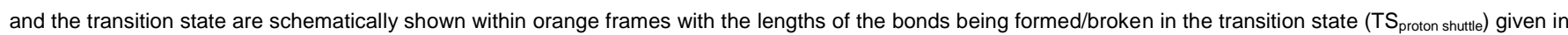

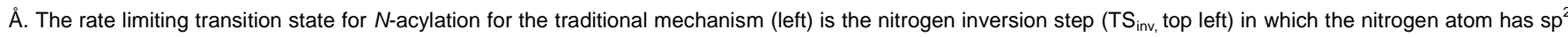
like character and the Ser $\mathrm{O}_{\mathrm{y}}$-former carbonyl carbon bond is being broken (the lengths of the bonds being formed/broken in TS $\mathrm{S}_{\text {inv }}$ are given in $\AA$ ). The inversion step is necessary in order for the lone pair of the nitrogen atom to be pointing antiperiplanar to the Ser Oy-former carbonyl carbon bond, which is the well known ${ }^{[14 a]}$ stereoelectronically required conformation for amide bond synthesis (see also Figure S4). It should be noted that nitrogen inversion and amide bond formation is a concerted process at the B3LYP/6-31G(d,p) level of theory. To simulate the protein and water shell surrounding the large active site model, single-point calculations using a conductor-like polarizable continuum model ${ }^{[36]}$ were performed for $\varepsilon=2$ (the level of the rate limiting transition states shown in red and blue for the two mechanisms for $(R)$-alaninol) and $\varepsilon=80$ (levels not shown in the figure). The relative energies were essentially unaffected by a continuum surrounding the active site model and for water the activation barriers were $20.1 \mathrm{kcal} / \mathrm{mol}$ for the traditional mechanism and $19.7 \mathrm{kcal} / \mathrm{mol}$ for the proton shuttle. The reduced barrier for the proton shuttle mechanism of $\mathrm{N}$-acylation for $(R)$-alaninol compared to the traditional mechanism, that would be the pathway for a (monosubstituted) amine, is in accordance with the experimental results that amino alcohols display increased $k_{\text {cat }}$-values for $N$-acylation (Table 1 ). The proton shuttle does not work for $O$-acylation since a lone pair of the oxygen will point towards the (developing) negative charge of the carbonyl oxygen of the acyl enzyme or towards a lone pair on Ser105 $\mathrm{O}_{Y}$ in TS (see Figure S6, S11-S13). This causes the hydroxyl oxygen-carbonyl carbon distance to increase in transition state for the proton shuttle of $O$-acylation and the position of the catalytic base $(\mathrm{H} 224)$ is no longer optimal as compared to $\mathrm{N}$-acylation. We estimate that the barrier for the proton shuttle of $\mathrm{O}$-acylation is $39 \mathrm{kcal} / \mathrm{mol}$ at the B3LYP/6-31G(d,p) level of theory in the large active site model (Figure S12) thus making O-acylation highly disfavoured.

(Figure 2) can be understood in terms of orbitals and stereoelectronic effects. To clarify this it is adequate to compare lipase catalyzed $\mathrm{N}$-acylation of amino alcohols with the reaction mechanism of amidases. It is well known that esterases are poor catalysts in the hydrolysis/synthesis of amide bonds. ${ }^{[16]}$ Nitrogen inversion or rotation is required in the enzymatic mechanism for amide bond hydrolysis/synthesis ${ }^{[37]}$ (see Figure S14 in Supporting Information). This is because the nitrogen lone pair needs to be situated antiperiplanar to the bond formed/cleaved between the nucleophilic group and the carbonyl carbon of the amide in 


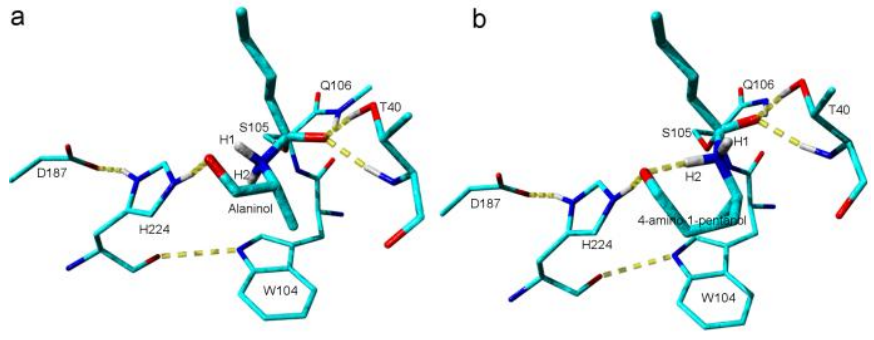

Figure 3. Snapshots from the MD-simulations of the tetrahedral intermediate representing the transition state for the proton shuttle mechanism of $\mathrm{N}$-acylation

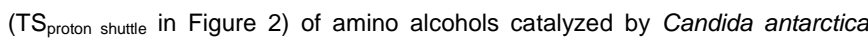
lipase B. (A) $\mathrm{N}$-acylation of $(R$ )-alaninol (1b) (B) $\mathrm{N}$-acylation of $(R)$-4-amino-1pentanol (1c). The catalytic amino acids (S105, H224, D187) as well as oxyanion hole (T40 and Q106) are shown. W104 forms the bottom of the so called stereoselectivity pocket in Candida antarctica lipase B. Substrates are shown in thick sticks. Color code: Cyan - carbon, Red - oxygen, Blue - nitrogen, White - hydrogen. Not all atoms are shown for clarity reasons. Hydrogen bonds are indicated with dashed yellow lines. The two protons sitting on the scissile nitrogen are labelled ( $\mathrm{H} 1$ and $\mathrm{H} 2)$.

Table 3. Distances and angles between atoms involved in proton transfer for the proton shuttle mechanism of $\mathrm{N}$-acylation of amino alcohols using Candida antarctica lipase $B{ }^{\left[{ }^{[a]}\right.}$

\begin{tabular}{|c|c|c|c|}
\hline Hydrogen bond & $\begin{array}{c}\text { Distance } \\
{[\AA]}\end{array}$ & $\begin{array}{c}\text { Angle D-H---A }{ }^{[b]} \\
\text { [degrees] }\end{array}$ & $\begin{array}{c}\text { Angle }-\mathrm{H}---\mathrm{AX}^{[\mathrm{b}]} \\
\text { [degrees] }\end{array}$ \\
\hline \multicolumn{4}{|l|}{ (R)-Alaninol } \\
\hline $\mathrm{NH} 1---\mathrm{O}^{[c]}$ & $1.6(2.5)$ & $141(96)$ & $85(74)$ \\
\hline NH2---O ${ }^{[c]}$ & $1.8(2.8)$ & $134(77)$ & $81(75)$ \\
\hline $\begin{array}{l}\text { HisNH to O in alaninol } \\
(R) \text {-4-amino-1-pentano }\end{array}$ & $1.5(1.8)$ & $171(156)$ & $104(112)$ \\
\hline $\mathrm{NH} 1--\mathrm{O}^{[\mathrm{c}]}$ & $1.6(2.7)$ & $168(107)$ & $90(88)$ \\
\hline NH2---O ${ }^{[c]}$ & $1.6(2.6)$ & $171(111)$ & $105(78)$ \\
\hline $\begin{array}{l}\text { HisNH to } \mathrm{O} \text { in } \\
4 \text {-amino-1-pentanol }\end{array}$ & $1.5(1.9)$ & $163(147)$ & $142(96)$ \\
\hline
\end{tabular}

[a] Based on the $8 \mathrm{~ns}$ "production phase" of the MD-simulations of the tetrahedral intermediate representing transition state $\left(\mathrm{TS}_{\text {proton shutle }}\right.$ in Figure 2). The values for the best hydrogen bond are given, with average values for all 8000 snapshots given within brackets. [b] The two angles involved in hydrogen bond formation (donor-H---acceptor and -H---acceptor-X). [c] The two individual protons sitting on the scissile nitrogen in the transition state model. See Figure 3.

accordance with stereoelectronic theory in chemistry introduced by Deslongchamps. ${ }^{[14]}$ The stereoelectronic effect is caused by a stabilizing $n-\sigma^{*}$ orbital interaction in the TS worth several $\mathrm{kcal} / \mathrm{mol}$. Our proposed reaction mechanism for lipase catalyzed $\mathrm{N}$ acylation of amino alcohols and 1,2-diaminopropane (7) (involving the transfer of two protons in the transition state) and methoxy-2propylamine (involving the transfer of one proton in the transition state) leads to the direct formation of a tetrahedral intermediate in a stereoelectronically favourable conformation for facile amide bond synthesis without the need for nitrogen inversion (Scheme 1, Figure S4-S6 Supporting Information).

In order to make the picture of enzyme catalyzed $\mathrm{N}$-acylation of amino alcohols more complete it is important to include the amino alcohols of longer chain length (1c-d) in the analysis as well. For shorter amino alcohols only the $\mathrm{N}$-acylated product was observed experimentally whereas $\mathrm{O}$-acylation was predominant for the longer amino alcohols 4-amino-1-pentanol (1c) and 6amino-1-hexanol (1d) (Table 1). We performed 10 ns MDsimulations of an intermediate mimicking the transition state for

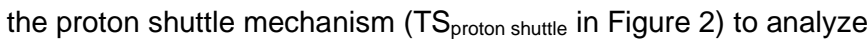
this difference in more detail. A snapshot from the MDsimulations of $(R)$-alaninol and $(R)$-4-amino-1-pentanol is shown in Figure 3. The average lengths and angles for the hydrogen bonds relevant for the proton shuttle mechanism are given in Table 3. A hydrogen bond donated by the amino group and accepted by the hydroxyl oxygen of the amino alcohol can be formed at the same time as the hydroxyl proton forms a hydrogen bond with the enzyme catalytic base $(\mathrm{H} 224)$, which will lead to our proposed "proton shuttle" mechanism in accordance with the $a b$ initio calculations. However, the two protons sitting on the amino group of the amino alcohol (labelled $\mathrm{H} 1$ and $\mathrm{H} 2$ in Figure $3 \mathrm{~A}$ and Figure $3 \mathrm{~B}$ respectively) are not identical since upon proton transfer they lead to different conformations of the nitrogen lone pair in the formed tetrahedral intermediate. Only abstraction of the proton for which the $\mathrm{NH}$-bond is pointing antiperiplanar to the Ser $\mathrm{O}_{\mathrm{Y}}-\mathrm{C}$ bond (the proton labelled $\mathrm{H} 1$ in Figure 3) will lead to a tetrahedral intermediate with a stereoelectronically favourable conformation for amide bond synthesis (the abstraction of this proton was accounted for in our ab initio calculations of the proton shuttle mechanism of $\mathrm{N}$-acylation using the large active site model, Figure 1 and Figure 2). Interestingly, from the MDsimulations we found that for the shorter amino alcohol $(R)$ alaninol (1b) there was a preference for the hydrogen bond donated by the $\mathrm{NH}$-group pointing antiperiplanar to the Ser $\mathrm{O}_{\mathrm{Y}}-\mathrm{C}$ bond to form (i.e. involving $\mathrm{H} 1$ in Figure 3 ). We found the situation to be the opposite for the longer amino alcohol $(R)$-4-amino-1pentanol where a hydrogen bond involving the other proton was preferred (the proton labelled $\mathrm{H} 2$ in Figure 3 ). For the longer amino alcohol the formation of a tetrahedral intermediate in an unfavourable stereoelectronic conformation will result from such proton abstraction (as shown in the snapshot in Figure 3B). Nitrogen inversion (or rotation) in such an unfavourable tetrahedral intermediate is necessary to prepare for the breakdown of the intermediate and no advantage over "traditional" $\mathrm{N}$-acylation of an alkylamine is expected. This is in accordance with the fact that $O$-acylation was predominant for the larger amino alcohols (Table 1). Furthermore, from Table 2 it can be concluded that formation of the required intramolecular hydrogen bond for the proton shuttle mechanism of $\mathrm{N}$-acylation is difficult for longer amino alcohols. Moreover entropic effects disfavours the formation of larger rings for amino alcohols ${ }^{[38]}$ and consequently the importance of the proton shuttle mechanism, dependant on such ring formation, will decrease. This is in accordance with the experimental finding that $O$-acylation becomes predominant for the longer amino alcohols caused by nucleophilic attack of the open chain. In fact the entropic cost of ring formation can be estimated to be $5 \mathrm{kcal} / \mathrm{mol}$ higher for the longer amino alcohol 4-amino-1-pentanol (1c) as compared to alaninol (1b) based on gas-phase experimental data. ${ }^{[38]}$ 1,2Diaminopropane $(7)$ showed the highest reaction rate for $N$ acylation (Table 1) which is in accordance with the fact that the intramolecular hydrogen bond in the molecular ion of diamines is considerably stronger than for corresponding amino alcohols. ${ }^{[30]}$ It is interesting to see that the reaction rate for lipase catalyzed $\mathrm{N}$ acylation of methoxy-2-propylamine (9) is only two fold lower than the reaction rate for $(R)$-alaninol (1b). A reduction in rate is expected since the methylated oxygen in methoxy-2-propylamine 
lacks a hydrogen to donate to the enzyme catalytic base during proton shuttling. Therefore the ether oxygen works as a bridging atom between the amino group and the enzyme catalytic base with proton transfer in two steps in this case. The molecular ions of polyethers are known to form very strong intramolecular hydrogen bonds. ${ }^{[38]}$

Finally there is an additional driving force for $\mathrm{N}$-acylation to occur according to our proposed mechanism. Upon formation of the tetrahedral intermediate, an $\mathrm{NH}---\mathrm{O}$ hydrogen bond in the near attack complex is replaced with a stronger $\mathrm{OH}---\mathrm{N}$ hydrogen bond (Table 2). Ring formation in the enzyme active site is further promoted by the formation of a hydrogen bond between $\mathrm{H} 224$ and the additional functional group present in the substrate.

\section{Conclusion}

We propose a proton shuttle reaction mechanism for lipase catalyzed $\mathrm{N}$-acylation of amino alcohols in which two protons are transferred in transition state coincidently with nucleophilic attack. Our proton shuttle mechanism is not dependent on acyl migration from an ester intermediate and can explain the enhanced reaction rate for enzyme catalyzed $\mathrm{N}$-acylation of diamines and methoxy2-propylamine for which $\mathrm{O}$ - to $\mathrm{N}$-acyl migration can not occur. A Linear Free Energy Relationship (LFER) analysis indicated that the difunctionalized amines afforded a substrate assisted rate acceleration by the same reaction mechanism. Furthermore the LFER analysis was consistent with partial proton transfer in the rate limiting transition state which is in accordance with our suggested proton shuttle reaction mechanism. By using DFT ab initio calculations on a very large active site model we found that our proposed mechanism had a lower barrier of activation compared to traditional $\mathrm{N}$-acylation for which proton shuffling does not occur. Moreover we demonstrated the feasibility of using quantum mechanics on very large active site models to study complex biochemical problems. The proton shuttle reaction mechanism leads to the formation of a tetrahedral intermediate in a stereoelectronically favourable conformation for facile amide bond synthesis which provides a physical explanation of the rate increase for enzyme catalyzed $\mathrm{N}$-acylation of amino alcohols and other difunctionalized amines. The mechanism is facilitated by the preference of amino alcohols to form intramolecular hydrogen bonds which makes the substrate amino alcohol adopting a conformation that is preorganized for proton shuttling, a property that to our best knowledge was previously not known. Our proposed proton shuttle mechanism for lipase catalyzed $N$ acylation of amino alcohols provides an interesting link to amidases, for which the production of a stereoelectronically favourable conformation of the nitrogen lone pair is facilitated by a hydrogen bond in transition state. ${ }^{[27]}$ Likewise, in the ribosome, proton shuttling is lowering the barrier of activation for peptide bond synthesis. ${ }^{[32 b]}$

\section{Experimental Section}

\section{Enzyme and chemicals}

Novozym ${ }^{\circledast} 435$ (immobilized Candida antarctica lipase B), was kindly provided by Novozymes A/S, Bagsvaerd, Denmark. (R)-2-butanol (99\%), $(R)$-2-butylamine (99\%), 1,2-propanediol ( $\geq 99.5 \%), \quad 1,2$ diaminopropane ( $\geq 98 \%)$, 1-amino-2-propanol (93\%), alaninol $(98 \%)$ 1-methoxy-2-propylamine (95\%) and 6-amino-1-hexanol ( $\geq 97 \%)$, as well as 2-methyl-2-butanol (99\%) and acetonitrile for luminescence were purchased from Sigma-Aldrich (St Louis, USA). 4-amino-1pentanol was from Santa Cruz Biotechnology (USA). Myristic acid and acetic acid were from Fluka (St Quentin-Fallavier, Switzerland). All chemicals were dried over molecular sieves. Pure water was obtained via a Milli-Q system (Millipore, France). Acetonitrile and methanol were purchased from Carlo ERBA (Val-de-Reuil, France).

\section{Active site titration}

Active site titration was performed by using the suicide inhibitor 4methylumbelliferyl hexylphosphonate. The inhibitor was added to beads $(10 \mathrm{mg})$, which contained immobilized lipase, to a final concentration of $50 \mu \mathrm{M}$. Acetonitrile was added to a final volume of 1 $\mathrm{mL}$. The fluorescence intensity was analyzed by adding $100 \mu \mathrm{L}$ sample solution to $900 \mu \mathrm{L}$ buffer containing $100 \mathrm{mM}$ Tris- $\mathrm{HCl}, 1 \mathrm{mM}$ $\mathrm{CaCl}_{2}, \mathrm{pH} 8.0$ and by measuring the signal by using a luminescence spectrometer (Luminescence Spectrometer Model LS-50B, PerkinElmer, MA, USA). The excitation wavelength was $\lambda=360 \mathrm{~nm}$ and the emission wavelength was $\lambda=445 \mathrm{~nm}$. The amount of active sites were calculated from a standard curve of the linear relationship between fluorescence intensity and the concentration of the leaving group 4-methylumbelliferone. The relationship between fluorescence intensity and the amount of beads containing immobilized enzyme was linear. The resulting active protein load on the support (\%weight/weight) was found to be $4.7 \%$ which corresponds to an active site concentration of $14 \mu \mathrm{M}$ when $10 \mathrm{mg}$ beads per $\mathrm{ml}$ are used.

\section{Enzymatic reactions}

Initial rate measurements were performed at $55^{\circ} \mathrm{C}$ in 2-methyl-2butanol as solvent. Various amounts of acyl acceptor (25-350 mM) and $175 \mathrm{mM}$ of myristic acid as acyl donor were incubated for 10 minutes prior to addition of 10 or $50 \mathrm{gl}^{-1}$ of beads with immobilized Candida antarctica lipase B for the acylation of 2-butanol and 2butylamine respectively. For the other acyl acceptors $5 \mathrm{gl}^{-1}$ of beads with immobilized enzyme was used. $100 \mu \mathrm{l}$ samples were taken at intervals and centrifuged at $10000 \mathrm{xg}$. The supernatant was analyzed by LC-MS. Initial rates were calculated from the linear relationship of the total concentration of products against reaction time. These results were used to determine apparent $k_{c a t}$ values from LineweaverBurk reciprocal plots.

\section{HPLC analysis}

Structural and quantitative analysis of reaction products were conducted using a LC/MS-ES system from Agilent (1100 LC/MSD Trap mass spectrometer VL) with a C18 Uptisphere 300 A OD column $(250 \times 4 \mathrm{~mm}, 5 \mu \mathrm{m}$, Interchim) for the analysis of reaction media for acylation of $(R)$-2-butanol and a C18 Prontosil 120-5-C18-AQ column $(250 \times 4 \mathrm{~mm}, 5 \mu \mathrm{m}$; Bischoff Chromatography) for the analysis of other reaction media. Products were detected and quantified by differential refractometry and UV detection at $210 \mathrm{~nm}$. Low-resolution mass spectral analyses were obtained by electrospray in the positive detection mode. Nitrogen was used as the drying gas at 15 I min-1 and $350{ }^{\circ} \mathrm{C}$ at a nebulizer pressure of 4 bars. The scan range was $50-1000 \mathrm{~m} / \mathrm{z}$ using five averages and $13,000 \mathrm{~m} / \mathrm{z}$ per second resolution. The capillary voltage was $4000 \mathrm{~V}$. Processing was done offline using HP Chemstation software.

Various eluent systems were used depending on the acyl acceptor used. Reaction samples resulting from the acylation of $(R)$-2-butanol and $(R)$-2-butylamine were eluted with acetonitrile/water/acetic acid $(90: 10: 0.1, \mathrm{v} / \mathrm{v} / \mathrm{v})$ at room temperature and at a flow rate of $1 \mathrm{ml} \mathrm{min}$ 1. Reaction samples resulting from the acylation of 1-methoxy-2propylamine and 1,2-diaminopropane were eluted with methanol/water/acetic acid (95:5:0.1 and 93:7:0.1, v/v/v, respectively) at room temperature and at a flow rate of $1 \mathrm{ml} \mathrm{min-1}$. Concerning the separation of products resulting from the acylation of other acyl acceptors, two solvent gradients were used. These gradients were 
derived from two eluent mixtures, solvent $A$ : acetonitrile / water / acetic acid (77:23:0.1, v / v / v) and solvent B: methanol / acetic acid (100:0.1, v / v ). Analysis of products resulting from the acylation of 1,2-propanediol and the disappearance of myristic acid were performed by using the gradient described in Table S3 (Supporting Information) at room temperature and for analysis of products resulting from acylation of amino-alcohols and the disappearance of myristic acid, by using the gradient described in Table S4 at room temperature.

\section{Product Characterization}

The products formed were characterized and confirmed by $1 \mathrm{H} N M R$, mass spectroscopy and infrared spectroscopy after purification via preparative HPLC. ${ }^{1} \mathrm{H}-\mathrm{NMR}$ were recorded on a JEOL-JNM LA400 spectrometer $(400 \mathrm{MHz})$ with tetramethylsilane as an internal reference. Samples were prepared in $\mathrm{CDCl}_{3}$. Infra-Red (IR) spectra were recorded using a Perkin-Elmer Spectrum 100 ATR spectrometer.

N-myristyl 1-amino-2-propanol (3a): ${ }^{1} \mathrm{H}$ NMR (400 MHz, $\mathrm{CDCl}_{3}, \delta$ ppm): $\delta 0.88$ (t, $\left.3 \mathrm{H}, J=6.55 \mathrm{~Hz},-\mathrm{CH}_{2}-\mathrm{CH}_{3}\right), 1.19(\mathrm{~d}, 3 \mathrm{H}, J=5.61 \mathrm{~Hz}$, $\left.-\mathrm{CH}-\mathrm{CH}_{3}\right), 1.25\left(\mathrm{~m}, 2 \mathrm{OH},-\mathrm{CH}_{2}\right.$ - of myristyl chain), $1.64\left(\mathrm{~m}, 2 \mathrm{H},-\mathrm{CH}_{2}\right.$ $\mathrm{CH}_{2}-\mathrm{CO}-\mathrm{NH}$ - of myristyl chain), 2.21 (t, $2 \mathrm{H}, \mathrm{J}=7.49 \mathrm{~Hz},-\mathrm{CH}_{2}-\mathrm{CH}_{2}$ CO-NH- of myristyl chain), $2.72(\mathrm{~d}, 1 \mathrm{H}, \mathrm{J}=3.74 \mathrm{~Hz},-\mathrm{OH}), 3.13(\mathrm{~m}$ $\left.1 \mathrm{H},-\mathrm{CH}-\mathrm{CH}_{2}-\mathrm{NH}-\right), 3.44\left(\mathrm{~m}, 1 \mathrm{H},-\mathrm{CH}-\mathrm{CH}_{2}-\mathrm{NH}-\right), 3.92(\mathrm{~m}, 1 \mathrm{H},-\mathrm{CH}-)$, $5.95(\mathrm{~s}, 1 \mathrm{H},-\mathrm{NH}-)$. IR $v_{\max }\left(\mathrm{cm}^{-1}\right): 3100-3500(\mathrm{O}-\mathrm{H}$, alcohol and $\mathrm{N}-\mathrm{H}$, amide), 2800-3000 ( $\mathrm{CH}$ of myristyl chain), 1619 ( $\mathrm{C}=\mathrm{O}$, amide), 1571 (N-H, amide). $m / Z$ (LR-ESI $\left.{ }^{+}\right) \mathrm{C}_{17} \mathrm{H}_{36} \mathrm{NO}_{2}\left(\mathrm{M}+\mathrm{H}^{+}\right.$), found: 286.4 (theoretical: 286.48).

N,O-dimyristyl 1-amino-2-propanol (4a): ${ }^{1} \mathrm{H}$ NMR (400 $\mathrm{MHz}, \mathrm{CDCl}_{3}$, $\delta \mathrm{ppm}): \delta 0.88\left(\mathrm{t}, 6 \mathrm{H}, J=6.55 \mathrm{~Hz}, 2 \mathrm{x}-\mathrm{CH}_{2}-\mathrm{CH}_{3}\right), 1.22(\mathrm{~d}, 3 \mathrm{H}, J=6.39$ $\left.\mathrm{Hz},-\mathrm{CH}-\mathrm{CH}_{3}\right), 1.25\left(\mathrm{~m}, 40 \mathrm{H},-\mathrm{CH}_{2}\right.$ - of myristyl chain), $1.61(\mathrm{~m}, 4 \mathrm{H}, 2 \mathrm{x}$ $-\mathrm{CH}_{2}-\mathrm{CH}_{2}-\mathrm{CO}$ - of myristyl chain), 2.16 (t, $2 \mathrm{H}, \mathrm{J}=6.62 \mathrm{~Hz},-\mathrm{CH}_{2}-\mathrm{CH}_{2}$ CO-O- of myristyl chain), 2.30 (t, $2 \mathrm{H}, \mathrm{J}=6.62 \mathrm{~Hz},-\mathrm{CH}_{2}-\mathrm{CH}_{2}-\mathrm{CO}-\mathrm{NH}-$ of myristyl chain), $3.37\left(\mathrm{~m}, 1 \mathrm{H},-\mathrm{CH}_{-} \mathrm{CH}_{2}-\mathrm{NH}-\right), 3.45(\mathrm{~m}, 1 \mathrm{H},-\mathrm{CH}-$ $\left.\mathrm{CH}_{2}-\mathrm{NH}-\right), 4.99(\mathrm{~m}, 1 \mathrm{H},-\mathrm{CH}-), 5.69\left(\mathrm{~s}, 1 \mathrm{H}, \mathrm{C}-\mathrm{NH}-\mathrm{CH}_{2}-\right) . \mathrm{IR} v_{\max }(\mathrm{cm}$ $\left.{ }^{1}\right): 3291(\mathrm{~N}-\mathrm{H}$, amide), 2800-3000 ( $\mathrm{CH}$ of myristyl chain), $1725(\mathrm{C}=\mathrm{O}$ ester), 1641 ( $\mathrm{C}=\mathrm{O}$, amide), 1557 (N-H, amide). $\mathrm{m} / \mathrm{Z}$ (LR-ESI ${ }^{+}$) $\mathrm{C}_{31} \mathrm{H}_{62} \mathrm{NO}_{3} \mathrm{Na}\left(\mathrm{M}+\mathrm{Na}^{+}\right)$, found: 518.6 (theoretical: 518.85 ).

N-myristyl 2-amino-1-propanol (3b): ${ }^{1} \mathrm{H}$ NMR $\left(400 \mathrm{MHz}, \mathrm{CDCl}_{3}, \delta\right.$ ppm): $\delta 0.88\left(\mathrm{t}, 3 \mathrm{H}, J=6.06 \mathrm{~Hz},-\mathrm{CH}_{2}-\mathrm{CH}_{3}\right), 1.17(\mathrm{~d}, 3 \mathrm{H}, J=6.06 \mathrm{~Hz}$, $\left.-\mathrm{CH}-\mathrm{CH}_{3}\right), 1.25\left(\mathrm{~m}, 2 \mathrm{H},-\mathrm{CH}_{2}\right.$ - of myristyl chain), $1.63\left(\mathrm{~m}, 2 \mathrm{H},-\mathrm{CH}_{2}\right.$ $\mathrm{CH}_{2}-\mathrm{CO}-\mathrm{NH}$ - of myristyl chain), 2.19 (t, $2 \mathrm{H}, J=6.06 \mathrm{~Hz},-\mathrm{CH}_{2}-\mathrm{CH}_{2}$ CO-NH- of myristyl chain), $3.04(\mathrm{~s}, 1 \mathrm{H},-\mathrm{OH}), 3.27$ (dd, $1 \mathrm{H}, J=5,10$ $\mathrm{Hz},-\mathrm{CH}-\mathrm{CH}_{2}-\mathrm{OH}$ ), 3.46 (dd, $1 \mathrm{H}, \mathrm{J}=3.7,11 \mathrm{~Hz},-\mathrm{CH}-\mathrm{CH}_{2}-\mathrm{OH}$ ), 4.07 $(\mathrm{m}, 1 \mathrm{H},-\mathrm{CH}-), 5.7(\mathrm{~s}, 1 \mathrm{H},-\mathrm{NH}-) . \mathrm{IR} v_{\max }\left(\mathrm{cm}^{-1}\right): 3100-3500(\mathrm{O}-\mathrm{H}$, alcohol and $\mathrm{N}-\mathrm{H}$, amide), 2800-3000 ( $\mathrm{CH}$ of myristyl chain), 1638 (C=O, amide), $1543\left(\mathrm{~N}-\mathrm{H}\right.$, amide). $\mathrm{m} / \mathrm{Z}\left(\mathrm{LR}-\mathrm{ESI}^{+}\right) \mathrm{C}_{17} \mathrm{H}_{36} \mathrm{NO}_{2}\left(\mathrm{M}+\mathrm{H}^{+}\right)$, found: 286.4 (theoretical: 286.48).

N,O-dimyristyl 2-amino-1-propanol (4b): ${ }^{1} \mathrm{H}$ NMR (400 MHz, $\mathrm{CDCl}_{3}$, $\delta \mathrm{ppm}): \delta 0.88\left(\mathrm{t}, 6 \mathrm{H}, J=7.6 \mathrm{~Hz}, 2 \mathrm{x}-\mathrm{CH}_{2}-\mathrm{CH}_{3}\right), 1.16(\mathrm{~d}, 3 \mathrm{H}, J=7.6$ $\left.\mathrm{Hz},-\mathrm{CH}_{-} \mathrm{CH}_{3}\right), 1.25\left(\mathrm{~m}, 40 \mathrm{H},-\mathrm{CH}_{2}\right.$ - of myristyl chain), $1.6(\mathrm{~m}, 4 \mathrm{H}, 2 \mathrm{x}-$ $\mathrm{CH}_{2}-\mathrm{CH}_{2}-\mathrm{CO}$ - of myristyl chain), $2.14\left(\mathrm{t}, 2 \mathrm{H}, \mathrm{J}=7.2 \mathrm{~Hz},-\mathrm{CH}_{2}-\mathrm{CH}_{2}\right.$ CO-O- of myristyl chain), 2.32 (t, $2 \mathrm{H}, J=7.2 \mathrm{~Hz},-\mathrm{CH}_{2}-\mathrm{CH}_{2}-\mathrm{CO}-\mathrm{NH}$ - of myristyl chain), 4 (dd, $1 \mathrm{H}, J=4.4,10.7 \mathrm{~Hz},-\mathrm{CH}_{-} \mathrm{CH}_{2}-\mathrm{O}-$ ), 4.13 (dd, $\left.1 \mathrm{H}, J=4.9,10 \mathrm{~Hz},-\mathrm{CH}-\mathrm{CH}_{2}-\mathrm{O}-\right), 4.29(\mathrm{~m}, 1 \mathrm{H},-\mathrm{CH}-), 5.54(\mathrm{~d}, 1 \mathrm{H}, J=$ $\left.7.3 \mathrm{~Hz}, \mathrm{C}-\mathrm{NH}-\mathrm{CH}_{2}-\right)$. IR $v_{\max }\left(\mathrm{cm}^{-1}\right): 3301(\mathrm{~N}-\mathrm{H}$, amide), 2800-3000 ( $\mathrm{CH}$ of myristyl chain), 1737 ( $\mathrm{C}=\mathrm{O}$, ester), 1643 ( $\mathrm{C}=\mathrm{O}$, amide), 1542 $\left(\mathrm{N}-\mathrm{H}\right.$, amide). $\mathrm{m} / \mathrm{Z}\left(\mathrm{LR}-\mathrm{ESI}{ }^{+}\right) \mathrm{C}_{31} \mathrm{H}_{62} \mathrm{NO}_{3} \mathrm{Na}\left(\mathrm{M}+\mathrm{Na}^{+}\right)$, found: 518.6 (theoretical: 518.85 ).

O-myristyl 4-amino-1-pentanol (2c): ${ }^{1} \mathrm{H}$ NMR $\left(400 \mathrm{MHz}, \mathrm{CDCl}_{3}, \delta\right.$ ppm): $\delta 0.88\left(\mathrm{t}, 3 \mathrm{H}, J=6.99 \mathrm{~Hz},-\mathrm{CH}_{2}-\mathrm{CH}_{3}\right), 1.14(\mathrm{~d}, 3 \mathrm{H}, J=8 \mathrm{~Hz},-$ $\left.\mathrm{CH}-\mathrm{CH}_{3}\right), 1.25\left(\mathrm{~m}, 2 \mathrm{OH},-\mathrm{CH}_{2}\right.$ - of myristyl chain), $1.52(\mathrm{~m}, 4 \mathrm{H},-\mathrm{CH}-$ $\left.\mathrm{CH}_{2}-\mathrm{CH}_{2}-\mathrm{CH}_{2}-\mathrm{O}-\right)$, 1.62 (m, $2 \mathrm{H},-\mathrm{CH}_{2}-\mathrm{CH}_{2}-\mathrm{CO}-\mathrm{O}$ - of myristyl chain), 2.22 (t, $1 \mathrm{H}, J=7.16 \mathrm{~Hz},-\mathrm{CH}_{2}-\mathrm{CH}_{2}-\mathrm{CO}-\mathrm{O}$ - of myristyl chain), 2.29 (t,
$1 \mathrm{H}, J=7.5 \mathrm{~Hz},-\mathrm{CH}_{2}-\mathrm{CH}_{2}$-CO-O- of myristyl chain), $3.43(\mathrm{~m}, 1 \mathrm{H},-$ $\left.\mathrm{CH}_{2}-\mathrm{CH}_{2}-\mathrm{O}-\right)$, $3.69\left(\mathrm{~m}, 1 \mathrm{H},-\mathrm{CH}_{2}-\mathrm{CH}_{2}-\mathrm{O}-\right), 4.1$ (m, $\left.1 \mathrm{H},-\mathrm{CH}-\right)$. IR $v_{\max }$ $\left(\mathrm{cm}^{-1}\right)$ : 3291 ( $\mathrm{N}-\mathrm{H}$, amine), 2800-3000 ( $\mathrm{CH}$ of myristyl chain), 1736 $\left(\mathrm{C}=\mathrm{O}\right.$, ester), $1557\left(\mathrm{~N}-\mathrm{H}\right.$, amine). $\mathrm{m} / \mathrm{Z}\left(\mathrm{LR}-\mathrm{ESI}^{+}\right) \mathrm{C}_{19} \mathrm{H}_{40} \mathrm{NO}_{2}\left(\mathrm{M}+\mathrm{H}^{+}\right)$, found: 314.2 (theoretical: 314.53 ).

N-myristyl 4-amino-1-pentanol (3c): ${ }^{1} \mathrm{H}$ NMR $\left(400 \mathrm{MHz}, \mathrm{CDCl}_{3}, \delta\right.$ ppm): $\delta 0.88$ (t, $\left.3 \mathrm{H}, J=6.58 \mathrm{~Hz},-\mathrm{CH}_{2}-\mathrm{CH}_{3}\right), 1.14(\mathrm{~d}, 3 \mathrm{H}, J=6.23 \mathrm{~Hz}$, $\left.-\mathrm{CH}-\mathrm{CH}_{3}\right), 1.25\left(\mathrm{~m}, 2 \mathrm{H},-\mathrm{CH}_{2}-\right.$ of myristyl chain), $1.53(\mathrm{~m}, 4 \mathrm{H},-\mathrm{CH}-$ $\mathrm{CH}_{2}-\mathrm{CH}_{2}-\mathrm{CH}_{2}-\mathrm{OH}$ ), 1.63 (m, $2 \mathrm{H},-\mathrm{CH}_{2}-\mathrm{CH}_{2}-\mathrm{CO}-\mathrm{NH}$ - of myristyl chain), $2.14\left(\mathrm{t}, 2 \mathrm{H}, J=7.27 \mathrm{~Hz},-\mathrm{CH}_{2}-\mathrm{CH}_{2}-\mathrm{CO}-\mathrm{NH}\right.$ - of myristyl chain), 2.94 (s, $1 \mathrm{H},-\mathrm{OH}), 3.67\left(\mathrm{~m}, 2 \mathrm{H},-\mathrm{CH}_{2}-\mathrm{CH}_{2}-\mathrm{OH}\right), 4.06(\mathrm{~m}, 1 \mathrm{H},-\mathrm{CH}-), 5.28(\mathrm{~s}$, $1 \mathrm{H},-\mathrm{NH}-)$. IR $v_{\max }\left(\mathrm{cm}^{-1}\right): 3200-3500(\mathrm{O}-\mathrm{H}$, alcohol and $\mathrm{N}-\mathrm{H}$, amide), 2800-3000 ( $\mathrm{CH}$ of myristyl chain), $1639(\mathrm{C}=\mathrm{O}$, amide), $1545(\mathrm{~N}-\mathrm{H}$, amide). $m / Z\left(\mathrm{LR}-\mathrm{ESI}^{+}\right) \mathrm{C}_{19} \mathrm{H}_{40} \mathrm{NO}_{2}\left(\mathrm{M}+\mathrm{H}^{+}\right)$, found: 314.2 (theoretical: 314.53).

N,O-dimyristyl 4-amino-1-pentanol (4c): ${ }^{1} \mathrm{H}$ NMR $\left(400 \mathrm{MHz}, \mathrm{CDCl}_{3}\right.$, $\delta \mathrm{ppm}): \delta 0.88\left(\mathrm{t}, 6 \mathrm{H}, J=7.43 \mathrm{~Hz}, 2 \mathrm{x}-\mathrm{CH}_{2}-\mathrm{CH}_{3}\right), 1.14(\mathrm{~d}, 3 \mathrm{H}, J=6.83$ $\left.\mathrm{Hz},-\mathrm{CH}-\mathrm{CH}_{3}\right), 1.25\left(\mathrm{~m}, 40 \mathrm{H},-\mathrm{CH}_{2}\right.$ - of myristyl chain), $1.53(\mathrm{~m}, 4 \mathrm{H},-$ $\left.\mathrm{CH}-\mathrm{CH}_{2}-\mathrm{CH}_{2}-\mathrm{CH}_{2}-\mathrm{O}-\mathrm{C}\right), 1.6$ (m, $4 \mathrm{H}, 2 \mathrm{x}-\mathrm{CH}_{2}-\mathrm{CH}_{2}-\mathrm{CO}$ - of myristyl chain), 2.14 (t, $4 \mathrm{H}, J=7.08 \mathrm{~Hz},-\mathrm{CH}_{2}-\mathrm{CH}_{2}$-CO- of myristyl chain), 3.68 $\left(\mathrm{m}, 2 \mathrm{H},-\mathrm{CH}_{2}-\mathrm{CH}_{2}-\mathrm{O}-\mathrm{C}\right), 4.07(\mathrm{~m}, 1 \mathrm{H},-\mathrm{CH}-), 5.27(\mathrm{~d}, 1 \mathrm{H}, \mathrm{J}=6.86 \mathrm{~Hz}$, $-\mathrm{NH}-)$. IR $v_{\max }\left(\mathrm{cm}^{-1}\right): 3304$ (N-H, amide), 2800-3000 ( $\mathrm{CH}$ of myristyl chain), $1732(\mathrm{C}=\mathrm{O}$, ester $), 1640(\mathrm{C}=\mathrm{O}$, amide $), 1546(\mathrm{~N}-\mathrm{H}$, amide $)$. $\mathrm{m} / \mathrm{Z}\left(\mathrm{LR}-\mathrm{ESI}^{+}\right) \mathrm{C}_{33} \mathrm{H}_{66} \mathrm{NO}_{3} \mathrm{Na}\left(\mathrm{M}+\mathrm{Na}^{+}\right)$, found: 546.2 (theoretical: 546.9).

O-myristyl 6-amino-1-hexanol (2d): ${ }^{1} \mathrm{H}$ NMR $\left(400 \mathrm{MHz}, \mathrm{CDCl}_{3}, \delta\right.$ ppm): $\delta 0.88\left(\mathrm{t}, 3 \mathrm{H}, J=7.28 \mathrm{~Hz},-\mathrm{CH}_{2}-\mathrm{CH}_{3}\right), 1.25\left(\mathrm{~m}, 2 \mathrm{OH},-\mathrm{CH}_{2}-\right.$ of myristyl chain), 1.55 (m, 2H, - $\mathrm{CH}_{2}-\mathrm{CH}_{2}-\mathrm{CO}-\mathrm{O}$ - of myristyl chain), 1.62 (m, $\left.4 \mathrm{H},-\mathrm{CH}_{2}-\mathrm{CH}_{2}-\mathrm{CH}_{2}-\mathrm{CH}_{2}-\mathrm{NH}_{2}\right), 2.28\left(\mathrm{t}, 2 \mathrm{H}, J=7.65 \mathrm{~Hz},-\mathrm{CH}_{2}-\mathrm{CH}_{2}\right.$ CO-O- of myristyl chain), $2.81\left(\mathrm{~s}, 2 \mathrm{H},-\mathrm{NH}_{2}\right), 3.64(\mathrm{t}, 2 \mathrm{H}, J=6.47 \mathrm{~Hz}$, $-\mathrm{CH}_{2}-\mathrm{CH}_{2}-\mathrm{NH}_{2}$ ), 4.04 (t, $\left.2 \mathrm{H}, J=6.47 \mathrm{~Hz},-\mathrm{CH}_{2}-\mathrm{CH}_{2}-\mathrm{O}-\mathrm{CO}-\mathrm{CH}_{2}\right)$. IR $v$ $\max \left(\mathrm{cm}^{-1}\right): 3400(\mathrm{~N}-\mathrm{H}$, amine), 2800-3000 ( $\mathrm{CH}$ of myristyl chain), 1736 $\left(\mathrm{C}=\mathrm{O}\right.$, ester), $1544\left(\mathrm{~N}-\mathrm{H}\right.$, amine). $m / Z\left(\right.$ LR-ESI $\left.{ }^{+}\right) \mathrm{C}_{20} \mathrm{H}_{42} \mathrm{NO}_{2}\left(\mathrm{M}+\mathrm{H}^{+}\right)$, found: 329.5 (theoretical: 328.56 ).

N-myristyl 6-amino-1-hexanol (3d): ${ }^{1} \mathrm{H}$ NMR $\left(400 \mathrm{MHz} \mathrm{CDCl}_{3}, \delta\right.$ ppm): $\delta 0.88\left(\mathrm{t}, 3 \mathrm{H}, J=7.5 \mathrm{~Hz},-\mathrm{CH}_{2}-\mathrm{CH}_{3}\right), 1.25\left(\mathrm{~m}, 2 \mathrm{OH},-\mathrm{CH}_{2}-\right.$ of myristyl chain), $1.51\left(\mathrm{~m}, 2 \mathrm{H},-\mathrm{CH}_{2}-\mathrm{CH}_{2}-\mathrm{CO}-\mathrm{O}\right.$ - of myristyl chain), 1.59 (m, $4 \mathrm{H},-\mathrm{CH}_{2}-\mathrm{CH}_{2}-\mathrm{CH}_{2}-\mathrm{CH}_{2}-\mathrm{OH}$ ), 2.26 (t, $2 \mathrm{H}, J=7.65 \mathrm{~Hz},-\mathrm{CH}_{2}-\mathrm{CH}_{2-}$ $\mathrm{CO}-\mathrm{OH}$ of myristyl chain), $2.72(\mathrm{~s}, 1 \mathrm{H},-\mathrm{OH}), 3.25(\mathrm{t}, 2 \mathrm{H}, J=7.07 \mathrm{~Hz}$, $\left.-\mathrm{CH}_{2}-\mathrm{CH}_{2}-\mathrm{OH}\right), 3.63\left(\mathrm{t}, 2 \mathrm{H}, J=7.29 \mathrm{~Hz},-\mathrm{CH}_{2}-\mathrm{CH}_{2}-\mathrm{NH}-\mathrm{CO}-\mathrm{CH}_{2}\right)$, $5.41(\mathrm{~s}, 1 \mathrm{H},-\mathrm{NH}-) . \mathrm{IR} v_{\max }\left(\mathrm{cm}^{-1}\right): 3385(\mathrm{O}-\mathrm{H}$, alcohol), $3314(\mathrm{~N}-\mathrm{H}$, amide), 2800-3000 ( $\mathrm{CH}$ of myristyl chain), 1634 ( $\mathrm{C}=\mathrm{O}$, amide), 1534 ( $\mathrm{N}-\mathrm{H}$, amide). $m / \mathrm{Z}\left(\mathrm{LR}-\mathrm{ESI}^{+}\right) \mathrm{C}_{20} \mathrm{H}_{42} \mathrm{NO}_{2}\left(\mathrm{M}+\mathrm{H}^{+}\right)$, found: 329.5 (theoretical: 328.56).

N,O-dimyristyl 6-amino-1-hexanol (4d): ${ }^{1} \mathrm{H} \mathrm{NMR}\left(400 \mathrm{MHz}, \mathrm{CDCl}_{3}\right.$, $\delta \mathrm{ppm}): \delta 0.88\left(\mathrm{t}, 6 \mathrm{H}, J=6.48 \mathrm{~Hz}, 2 \mathrm{x}-\mathrm{CH}_{2}-\mathrm{CH}_{3}\right), 1.25\left(\mathrm{~m}, 40 \mathrm{H},-\mathrm{CH}_{2^{-}}\right.$ of myristyl chain), $1.5\left(\mathrm{~m}, 4 \mathrm{H},-\mathrm{CH}_{2}-\mathrm{CH}_{2}-\mathrm{CO}\right.$ - of myristyl chain), 1.6 (m, $\left.4 \mathrm{H},-\mathrm{CH}_{2}-\mathrm{CH}_{2}-\mathrm{CH}_{2}-\mathrm{CH}_{2}-\mathrm{O}-\mathrm{C}\right), 2.15$ (t, $2 \mathrm{H}, \mathrm{J}=7.8 \mathrm{~Hz},-\mathrm{CH}_{2}-\mathrm{CH}_{2-}$ CO-NH-), 2.29 (t, $2 \mathrm{H}, J=7.8 \mathrm{~Hz},-\mathrm{CH}_{2}-\mathrm{CH}_{2}-\mathrm{CO}-\mathrm{NH}-$ ), 3.24 (q, 2H, $J=$ $\left.6.5 \mathrm{~Hz},-\mathrm{CH}_{2}-\mathrm{CH}_{2}-\mathrm{NH}-\right), 4.06\left(\mathrm{t}, 2 \mathrm{H}, \mathrm{J}=5.9 \mathrm{~Hz},-\mathrm{CH}_{2}-\mathrm{CH}_{2}-\mathrm{O}-\mathrm{CO}-\right.$ $\left.\mathrm{CH}_{2}\right), 5.4(\mathrm{~s}, 1 \mathrm{H},-\mathrm{NH}-)$. IR $v_{\max }\left(\mathrm{cm}^{-1}\right): 3298(\mathrm{~N}-\mathrm{H}$, amide), 2800-3000 ( $\mathrm{CH}$ of myristyl chain), $1726(\mathrm{C}=\mathrm{O}$, ester $), 1635(\mathrm{C}=\mathrm{O}$, amide), 1547 ( $\mathrm{N}-\mathrm{H}$, amide). $\mathrm{m} / \mathrm{Z}$ (LR-ESI $\left.{ }^{+}\right) \mathrm{C}_{34} \mathrm{H}_{67} \mathrm{NO}_{3} \mathrm{Na}\left(\mathrm{M}+\mathrm{Na}^{+}\right)$, found: 560.7 (theoretical: 560.93).

N-myristyl 1-methoxy-2-propylamine: ${ }^{1} \mathrm{H}$ NMR $\left(400 \mathrm{MHz}, \mathrm{CDCl}_{3}, \delta\right.$ ppm): $\delta 0.88$ (t, $\left.3 \mathrm{H}, J=6.79 \mathrm{~Hz},-\mathrm{CH}_{2}-\mathrm{CH}_{3}\right), 1.17$ (d, $3 \mathrm{H}, J=6.17 \mathrm{~Hz}$, $\left.-\mathrm{CH}-\mathrm{CH}_{3}\right), 1.26\left(\mathrm{~m}, 2 \mathrm{H},-\mathrm{CH}_{2^{-}}\right.$of myristyl chain), $1.62\left(\mathrm{~m}, 2 \mathrm{H},-\mathrm{CH}_{2}\right.$ $\mathrm{CH}_{2}$-CO-NH- of myristyl chain), 2.15 (t, $2 \mathrm{H}, \mathrm{J}=6.8 \mathrm{~Hz},-\mathrm{CH}_{2}-\mathrm{CH}_{2}-\mathrm{CO}$ $\mathrm{NH}$ - of myristyl chain), $2.19\left(\mathrm{t}, 1 \mathrm{H}, J=6.8 \mathrm{~Hz},-\mathrm{CH}-\mathrm{CH}_{2}-\mathrm{OCH}_{3}\right), 3.36$ $\left(\mathrm{m}, 3 \mathrm{H},-\mathrm{OCH} \mathrm{H}_{3}\right), 4.06\left(\mathrm{t}, 1 \mathrm{H}, J=6.45 \mathrm{~Hz},-\mathrm{CH}-\mathrm{CH}_{2}-\mathrm{OCH}_{3}\right), 4.16(\mathrm{~m}$, $1 \mathrm{H},-\mathrm{CH}-), 5.62(\mathrm{~d}, 1 \mathrm{H}, J=5.84 \mathrm{~Hz},-\mathrm{NH}-)$. IR $v_{\text {max }}\left(\mathrm{cm}^{-1}\right): 3304(\mathrm{~N}-\mathrm{H}$, amide), 2800-3000 ( $\mathrm{CH}$ of myristyl chain), 1634 ( $\mathrm{C}=\mathrm{O}$, amide), 1544 $\left(\mathrm{N}-\mathrm{H}\right.$, amide). $\mathrm{m} / \mathrm{Z}\left(\mathrm{LR}-\mathrm{ESI}{ }^{+}\right) \mathrm{C}_{18} \mathrm{H}_{38} \mathrm{NO}_{2}\left(\mathrm{M}+\mathrm{H}^{+}\right)$, found: 300.3 (theoretical: 300.51). 
1-N-myristyl 1,2-diaminopropane: ${ }^{1} \mathrm{H}$ NMR $\left(400 \mathrm{MHz}, \mathrm{CDCl}_{3}, \delta\right.$ ppm): $\delta 0.88$ (t, $\left.3 \mathrm{H}, J=6.67 \mathrm{~Hz},-\mathrm{CH}_{2}-\mathrm{CH}_{3}\right), 1.22(\mathrm{~d}, 3 \mathrm{H}, J=6.67 \mathrm{~Hz}$, $\left.-\mathrm{CH}-\mathrm{CH}_{3}\right), 1.25\left(\mathrm{~m}, 2 \mathrm{OH},-\mathrm{CH}_{2^{-}}\right.$of myristyl chain), 1.61 (q, $2 \mathrm{H}, J=$ $6.67 \mathrm{~Hz},-\mathrm{CH}_{2}-\mathrm{CH}_{2}-\mathrm{CO}-\mathrm{NH}$ - of myristyl chain), $1.96\left(\mathrm{~s}, 2 \mathrm{H},-\mathrm{NH}_{2}\right), 2.19$ (t, $2 \mathrm{H}, J=7.3 \mathrm{~Hz},-\mathrm{CH}_{2}-\mathrm{CH}_{2}-\mathrm{CO}-\mathrm{NH}$ - of myristyl chain), 3.21 (st, $1 \mathrm{H}, J$ $=5.9 \mathrm{~Hz},-\mathrm{CH}-), 3.27$ (qd, $\left.1 \mathrm{H}, J=2.6,11.8 \mathrm{~Hz},-\mathrm{CH}_{-} \mathrm{CH}_{2}-\mathrm{NH}-\right), 3.46$ (qd, $1 \mathrm{H}, J=3.24,13.6 \mathrm{~Hz},-\mathrm{CH}-\mathrm{CH}_{2}-\mathrm{NH}-$ ), 7.22 (t, $1 \mathrm{H}, J=4.42 \mathrm{~Hz}$, $\mathrm{NH}-$ ). $m / Z\left(\mathrm{LR}-\mathrm{ESI}^{+}\right) \mathrm{C}_{17} \mathrm{H}_{37} \mathrm{~N}_{2} \mathrm{O}\left(\mathrm{M}+\mathrm{H}^{+}\right)$, found: 285.4 (theoretical: 285.49).

1-O-myristyl 1,2-propanediol: ${ }^{1} \mathrm{H}$ NMR $\left(400 \mathrm{MHz}, \mathrm{CDCl}_{3}, \delta \mathrm{ppm}\right): \delta$ $0.88\left(\mathrm{t}, 3 \mathrm{H}, J=6.65 \mathrm{~Hz},-\mathrm{CH}_{2}-\mathrm{CH}_{3}\right), 1.22(\mathrm{~d}, 3 \mathrm{H}, J=3.3 \mathrm{~Hz},-\mathrm{CH}$ $\left.\mathrm{CH}_{3}\right), 1.24\left(\mathrm{~m}, 2 \mathrm{OH},-\mathrm{CH}_{2}\right.$ - of myristyl chain), $1.63\left(\mathrm{~m}, 2 \mathrm{H},-\mathrm{CH}_{2}-\mathrm{CH}_{2}\right.$ CO-O- of myristyl chain), $2.2(\mathrm{~s}, 1 \mathrm{H},-\mathrm{OH}-), 2.35$ (t, $2 \mathrm{H}, J=7.3 \mathrm{~Hz}$, $\mathrm{CH}_{2}-\mathrm{CH}_{2}$-CO-O- of myristyl chain), $3.93(\mathrm{dd}, 1 \mathrm{H}, J=6.3,11 \mathrm{~Hz},-\mathrm{CH}-$ $\left.\mathrm{CH}_{2}-\mathrm{O}-\right), 4(\mathrm{~m}, 1 \mathrm{H},-\mathrm{CH}-), 4.11$ (dd, $\left.1 \mathrm{H}, \mathrm{J}=3.1,11 \mathrm{~Hz},-\mathrm{CH}-\mathrm{CH}_{2}-\mathrm{O}-\right)$. $\mathrm{m} / \mathrm{Z}$ (LR-ESI $\left.{ }^{+}\right) \mathrm{C}_{17} \mathrm{H}_{35} \mathrm{O}_{3}\left(\mathrm{M}+\mathrm{H}^{+}\right)$, found: 287.2 (theoretical: 287.47).

2-O-myristyl 1,2-propanediol: ${ }^{1} \mathrm{H}$ NMR $\left(400 \mathrm{MHz}, \mathrm{CDCl}_{3}, \delta\right.$ ppm): $\delta$ $0.88\left(\mathrm{t}, 3 \mathrm{H}, J=6.65 \mathrm{~Hz},-\mathrm{CH}_{2}-\mathrm{CH}_{3}\right), 1.22(\mathrm{~d}, 3 \mathrm{H}, J=3.3 \mathrm{~Hz},-\mathrm{CH}-$ $\left.\mathrm{CH}_{3}\right), 1.24\left(\mathrm{~m}, 2 \mathrm{OH},-\mathrm{CH}_{2}\right.$ - of myristyl chain), $1.63\left(\mathrm{~m}, 2 \mathrm{H},-\mathrm{CH}_{2}-\mathrm{CH}_{2}\right.$ CO-O- of myristyl chain), $1.93(\mathrm{~s}, 1 \mathrm{H},-\mathrm{OH}), 2.32(\mathrm{t}, 2 \mathrm{H}, J=7.3 \mathrm{~Hz}$, $\mathrm{CH}_{2}-\mathrm{CH}_{2}$-CO-O- of myristyl chain), $3.65(\mathrm{dd}, 1 \mathrm{H}, J=6.3,11 \mathrm{~Hz},-\mathrm{CH}$ $\left.\mathrm{CH}_{2}-\mathrm{O}-\right)$, 3.68 (dd, $\left.1 \mathrm{H}, J=3.1,11 \mathrm{~Hz},-\mathrm{CH}_{-} \mathrm{CH}_{2}-\mathrm{O}-\right), 4.99(\mathrm{~m}, 1 \mathrm{H}$, $\mathrm{CH}-$ ). $\mathrm{m} / \mathrm{Z}$ (LR-ESI $\left.{ }^{+}\right) \mathrm{C}_{17} \mathrm{H}_{35} \mathrm{O}_{3}\left(\mathrm{M}+\mathrm{H}^{+}\right)$, found: 287.2 (theoretical: 287.47).

\section{Computational details}

Calculations to obtain the distribution of ground state amino alcohol conformers were performed by employing density functional theory (DFT) using the B3LYP hybrid density functional ${ }^{[39]}$ as implemented in US-GAMESS 12 JAN 2009 (R3)..$^{[40]}$ Geometry optimizations were carried out using the $6-31 \mathrm{G}(\mathrm{d}, \mathrm{p})$ basis set and by using the convergence criterion that the largest component of the gradient should be less than $5^{*} 10^{-4}$ Hartree/Bohr. Final energies were calculated using a larger basis set, $6-311+G(2 d, 2 p)$. All structures were verified to be minima by means of vibrational analysis at the same level of theory as for the optimization. Final energies were corrected for zero-point vibrational energies (ZPVE). The effect of solvation was taken into account by performing single-point calculations on the optimized structures using the CPCM polarizable continuum model ${ }^{[36]}$ using the large basis set and by adding the resulting solvation energy to the final energy. For our proposed proton shuttle mechanism of lipase catalyzed $\mathrm{N}$-acylation of amino alcohols, calculations were initiated in a small active site model of a serine hydrolase containing 47 atoms. The classical Ser/His/Asp catalytic triad was represented by a methanol molecule, an imidazole molecule and a formate ion in order to simulate a minimal serine hydrolase active site. The oxyanion hole was represented by two methano molecules. In our study the coordinates of the catalytic triad from PDB file 1LBT (Candida antarctica lipase B with Tween80) were used as a starting point. Ethanol amine was used as model of an amino alcohol molecule. Geometry optimizations were performed by DFT at the B3LYP/6-31G(d,p) level with the same convergence criterion as given above. Eigenvector-following as implemented in US-GAMESS was used to locate transition states. Vibrational analysis was performed at the same level of theory as for the optimizations and the transition state for the proton shuttle mechanism had one imaginary frequency that corresponded to nucleophilic attack and the transfer of two protons. The intrinsic reaction coordinate (IRC) was calculated to verify the reaction path. The small active site model was also used to calculate the hypothetical reaction mechanism for the proton shuttle corresponding to $\mathrm{O}$-acylation in the same way as for $\mathrm{N}$-acylation. The transition state for the proton shuttle mechanism of $O$-acylation of ethanol amine could be located using $\mathrm{HF} / 6-31 \mathrm{G}(\mathrm{d}, \mathrm{p})$ but could not be fully relaxed using DFT at the B3LYP/6-31G(d,p) level, presumably because of a very unfavourable interaction between the remaining free lone pair on the oxygen nucleophile and the developing negative charge on the acyl enzyme carbonyl oxygen in TS.
For the cluster ab initio calculations a large model of the active site of Candida antarctica lipase B that contained 205 atoms (which represented 14 amino acids) was used. The coordinates of the atoms were taken from the crystal structure 1LBT (to which hydrogens were added manually). A picture of the large active site model is given in Supporting Information, Figure S3. Residues were truncated such that only important side chains and/or peptide backbones were included in the model (see Figure S3). Atoms marked with an asterisk corresponds to backbone $\alpha$-carbons that were kept fixed during the simulations since the enzyme backbone does not have the ability to move freely. The fixation of such atoms, a standard technique in cluster ab initio calculations ${ }^{[34 \mathrm{~b}, 41]}$, gives rise to a few small imaginary frequencies, typically less than $40 \mathrm{i} \mathrm{cm}{ }^{-1}$. These imaginary frequencies have a very small effect on the ZPVE. As substrate, $(R)$-alaninol was used and the acyl enzyme contained four carbon atoms in the acyl chain in our large model (Figure S3). The ES-complex corresponded to the amino alcohol substrate complexed to the acyl enzyme. Intermediates and transition states in the large model were first obtained and verified (by vibrational analysis and by calculation of the intrinsic reaction coordinate (IRC)) using $\mathrm{HF} / 6-31 \mathrm{G}(\mathrm{d}, \mathrm{p})$. The resulting geometries obtained at the $\mathrm{HF} / 6-31 \mathrm{G}(\mathrm{d}, \mathrm{p})$ level were then used as the starting point for geometry optimizations using DFT at the B3LYP/6-31G(d,p) level, with the same convergence criterion as above. This strategy was especially efficient for the localization of transition states (the strategy is illustrated in Figure S7 in Supporting Information, the transition states were located by eigenvector following). The rate limiting transition state for the traditional mechanism of $\mathrm{N}$-acylation, with ZPVEs calculated at the same level of theory as for the optimizations taken into account, was found to be the nitrogen inversion step both at $\mathrm{HF} / 6-31 \mathrm{G}(\mathrm{d}, \mathrm{p})$ and B3LYP/6$31 \mathrm{G}(\mathrm{d}, \mathrm{p})$ (for a definition of the different mechanisms, see Figure S4S6 in Supporting Information). Nitrogen inversion (labelled TS $_{\text {inv }}$ in Figure S7) was found to be concerted with amide bond formation at the B3LYP/6-31G(d,p) level of theory, but a separate transition state from amide bond synthesis/breakdown at the HF/6-31G(d,p) level $\left(\mathrm{TS}_{2}\right.$ in Figure S7). Likewise by using MP2/6-31G(d,p) on the small active site model the inversion step was found to be a separate transition state that was not part of the breakdown of the tetrahedral intermediate (i.e. amide bond synthesis, see also Figure S4). It should be noted that amidases have a hydrogen bond that is in a perfect spatial arrangement for the stabilization of the transition state for nitrogen inversion, regardless of reaction mechanism. ${ }^{[27]}$ Since esterases lack this interaction ${ }^{[27]}$ we are not surprised to see that the transition state for nitrogen inversion was found to be rate limiting in the very large active site model of Candida antarctica lipase B. The proton shuttle mechanism for $\mathrm{N}$-acylation of $(R)$-alaninol was then calculated in the large active site model using DFT, with the coordinates from HF as starting point. Frequency calculations were again performed at the same level of theory as for the optimization (B3LYP/6-31G(d,p)) and the energies were corrected for ZPVE. The DFT optimized TS for the proton shuttle mechanism of $\mathrm{N}$-acylation obtained at the B3LYP/6-31G(d,p) level had an imaginary frequency of $1030 \mathrm{i} \mathrm{cm}$ that corresponded to nucleophilic attack and the transfer of two protons. Again the intrinsic reaction coordinate (IRC) was calculated to verify the reaction path. For the calculation of the TSmodel for the proton shuttle mechanism of $\mathrm{O}$-acylation, the $\mathrm{His} \mathrm{N}_{\varepsilon 2}-\mathrm{H}$ bond length was kept fixed at $1.08 \AA$ and the distance between the hydroxyl proton and oxygen of the amino alcohol was set to $1.18 \AA$. These bond lengths were found from the calculations in the small active site model containing 47 atoms. A frequency calculation on the structure for the TS-model of the proton shuttle involving $O$-acylation in the large active site model was performed using $\mathrm{HF} / 6-31 \mathrm{G}(\mathrm{d}, \mathrm{p})$, which resulted in one imaginary frequency of $1429 \mathrm{i} \mathrm{cm}$ (corresponding to nucleophilic attack of the oxygen and the transfer of two protons)

The effect of solvation of our large active site model was taken into account by using single-point calculations on the optimized structures using the CPCM polarizable continuum model with $\varepsilon=2$ and $\varepsilon=80$ respectively, which resulted in small effects on the relative energies. 
The software YASARA version 8.9.23 ${ }^{[42]}$ was used for all force field MD-simulations. All missing hydrogens were added to the starting structure 1LBT taken from the protein data bank and the hydrogen network was optimized by repeated minimizations and short molecular dynamics (MD) runs (1200 fs at $298 \mathrm{~K}$ ) using the Amber99 force field. The tetrahedral intermediate was constructed by attaching the nitrogen or oxygen of the substrate to the acyl enzyme (containing the $\mathrm{C}_{13} \mathrm{C}(=\mathrm{O})$-group originating from myristic acid) and by using the AUTOSMILES approach implemented in YASARA. ${ }^{[43]} 10$ ns MDsimulations were performed at $298 \mathrm{~K}$ under the canonical ensemble using a Berendsen thermostat. PME accounted for long-range electrostatics $^{[44]}$ during the MD-simulations of the tetrahedral intermediates and periodic boundary conditions were employed. The first 2 ns of each MD-simulation consisted of an equilibration phase.

\section{Acknowledgements}

The Royal Academy of Swedish Sciences is acknowledged for financial support as well as the Alexander von Humboldt foundation. The Swedish Center for High Performance Computing (PDC) is greatly acknowledged for computer time and technical support. This study was supported by the French ANR (National Research Agency) through the EXPENANTIO project (program CP2D). The author would like to thank R. Syrén for inspiration.

Keywords: Enzyme catalysis • Reaction mechanisms • Molecular modeling $•$ Amino alcohols $•$ Linear Free Energy Relationship

[1] a) F. Fache, E. Schulz, M. L. Tommasino, M. Lemaire, Chem. Rev. 2000 100, 2159-2231; b) S. M. Lait, D. A. Rankic, B. A. Keay, Chem. Rev. 2007, 107, 767-796

[2] D. J. Ager, I. Prakash, D. R. Schaad, Chem. Rev. 1996, 96, 835-875.

[3] a) Y. Yang, D. Wahler, J.-L. Reymond, Helv. Chim. Acta 2003, 86, 29282936; b) X. Chen, S.-H. Seow, T. Futterer, Rhodia Asia Pacific Pte, Limited, Singapore . 2009, US 20090048139; c) M. Breuer, K. Ditrich, T. Habicher, B. Hauer, M. Kesseler, R. Stuermer, T. Zelinski, Angew. Chem., Int. Ed. 2004, 43, 788-824; d) M. J. Climent, A. Corma, S. Iborra, Chem. Rev. 2011, 111, 1072-1133.

[4] a) A. Abiko, S. Masamune, Tetrahedron Lett. 1992, 33, 5517-5518; b) R Polt, M. A. Peterson, Tetrahedron Lett. 1990, 31, 4985-4986; c) D. J. Ager, M. B. East, Tetrahedron 1993, 49, 5683-5765; d) A. P. Kozikowski, Acc. Chem. Res. 1984, 17, 410-416.

[5] a) Y. A. Hannun, L. M. Obeid, Nat. Rev. Mol. Cell Biol. 2008, 9, 139-150 b) O. Cuvillier, G. Pirianov, B. Kleuser, P. G. Vanek, O. A. Coso, J. S. Gutkind, S. Spiegel, Nature 1996, 381, 800-803; c) J. M. Berg, J. L. Tymoczko, L. Stryer, Biochemistry, 5 ed., W H Freeman, New York, 2002; d) S. G. Rasmussen, B. T. DeVree, Y. Zou, A. C. Kruse, K. Y. Chung, T. S. Kobilka, F. S. Thian, P. S. Chae, E. Pardon, D. Calinski, J. M. Mathiesen, S. T. Shah, J. A. Lyons, M. Caffrey, S. H. Gellman, J. Steyaert, G. Skiniotis, W. I. Weis, R. K. Sunahara, B. K. Kobilka, Nature 2011, 477, 549-555.

[6] Y. Kita, Y. Nishii, T. Higuchi, K. Mashima, Angewandte Chemie 2012, 124, 5821-5824

[7] K. I. Skorey, V. Somayaji, R. S. Brown, J. Am. Chem. Soc. 1989, 111, $1445-1452$.

[8] J. Hine, M. N. Khan, J. Am. Chem. Soc. 1977, 99, 3847-3848.

[9] T. Storz, P. Dittmar, D. Grimler, M. Testa, H. Potgeter, D. Chappel, O. Hartmann, D. Niederer, M. Trueby, Org. Process Res. Dev. 2006, 10 1184-1191.

[10] M. M. Werber, Y. Shalitin, Bioorg. Chem. 1973, 2, 202-220.

[11] T. Ohshima, T. Iwasaki, Y. Maegawa, A. Yoshiyama, K. Mashima, J. Am Chem. Soc. 2008, 130, 2944-2945.

[12] a) E. Husson, C. Humeau, F. Blanchard, X. Framboisier, I. Marc, I. Chevalot, J. Mol. Catal. B: Enzym. 2008, 55, 110-117; b) D. Adlercreutz,
P. Tufvesson, A. Karlsson, R. Hatti-Kaul, Ind. Biotechnol. 2010, 6, 204211 ; c) F. Le Joubioux, Y. Ben Henda, N. Bridiau, O. Achour, M. Graber, T. Maugard, J. Mol. Catal. B: Enzym. 2012, dx.doi.org/10.1016/j.molcatb.2012.09.006

[13] T. Furutani, M. Furui, H. Ooshima, J. Kato, Enzyme Microb. Technol. 1996, 19, 578-584

[14] a) P. Deslongchamps, Tetrahedron 1975, 31, 2463-2490; b) G. Deslongchamps, P. Deslongchamps, Org. Biomol. Chem. 2011, 9, 5321 5333; c) D. G. Gorenstein, Chem. Rev. 1987, 87, 1047-1077.

[15] M. M. Mojtahedi, A. M. Saeed, M. M. Heravi, F. K. Behbahani, Monatsh. Chem. 2007, 138, 95-99.

[16] a) Y. Nakagawa, A. Hasegawa, J. Hiratake, K. Sakata, Protein Eng., Des. Sel. 2007, 20, 339-346; b) A. Zaks, A. M. Klibanov, Proc. Natl. Acad. Sci. U. S. A. 1985, 82, 3192-3196.

[17] F. Brotzel, Y. C. Chu, H. Mayr, J. Org. Chem. 2007, 72, 3679-3688.

[18] L. T. Kanerva, M. Kosonen, E. Vanttinen, T. T. Huuhtanen, M. Dahlqvist, Acta Chem. Scand. 1992, 46, 1101-1105.

[19] M. Skwarczynski, Y. Kiso, Curr. Med. Chem. 2007, 14, 2813-2823.

[20] a) W. Li, W. Du, Q. Li, T. Sun, D.-H. Liu, J. Mol. Catal. B: Enzym. 2010, 63, 17-22; b) L. Iddon, S. E. Richards, C. H. Johnson, J. R. Harding, I. D. Wilson, J. K. Nicholson, J. C. Lindon, A. V. Stachulski, Org. Biomol. Chem. 2011, 9, 926-934.

[21] H. Eberhard, O. Seitz, Org. Biomol. Chem. 2008, 6, 1349-1355.

[22] R. Greenhalgh, R. M. Heggie, M. A. Weinberger, Can. J. Chem. 1963 41, 1662-1670.

[23] S. P. Markey, T. Dudding, T.-C. L. Wang, J. Lipid Res. 2000, 41, $657-$ 662.

[24] P. Butz, R. T. Kroemer, N. A. Macleod, E. G. Robertson, J. P. Simons, J. Phys. Chem. A 2001, 105, 1050-1056.

[25] T. D. Smith, J. B. Gerken, P. V. Jog, J. D. Roberts, Org. Lett. 2007, 9, 4555-4557.

[26] N. A. Macleod, J. P. Simons, Phys. Chem. Chem. Phys. 2003, 5, 1123 1129

[27] P.-O. Syren, K. Hult, ChemCatChem 2011, 3, 853-860.

[28] P.-O. Syren, P. Hendil-Forssell, L. Aumailley, W. Besenmatter, F. Gounine, A. Svendsen, M. Martinelle, K. Hult, ChemBioChem 2012, 13, 645-648.

[29] M. I. Page, W. P. Jencks, J. Amer. Chem. Soc. 1972, 94, 8818-8827.

[30] M. Meot-Ner, Chem. Rev. 2005, 105, 213-284.

[31] N. A. Macleod, J. P. Simons, Phys. Chem. Chem. Phys. 2004, 6, 2821 2826.

[32] a) Q. Wang, J. Gao, Y. Liu, C. Liu, Chem. Phys. Lett. 2010, 501, 113117 ; b) D. A. Hiller, V. Singh, M.-H. Zhong, S. A. Strobel, Nature 2011, 476, 236-239; c) M. Pech, K. H. Nierhaus, ChemBioChem 2012, 13, 189 192; d) G. Wallin, J. Aaqvist, Proc. Natl. Acad. Sci. U. S. A. 2010, 107, 1888-1893.

[33] R.-Z. Liao, P. Georgieva, J.-G. Yu, F. Himo, Biochemistry 2011, 50, 1505-1513.

[34] a) L. Noodleman, T. Lovell, W.-G. Han, J. Li, F. Himo, Chem. Rev. 2004 104, 459-508; b) P. E. M. Siegbahn, F. Himo, Wiley Interdiscip. Rev.: Comput. Mol. Sci. 2011, 1, 323-356; c) O. Amata, T. Marino, N. Russo, M. Toscano, J. Am. Chem. Soc. 2011, 133, 17824-17831.

[35] C. J. Cramer, D. G. Truhlar, J. Am. Chem. Soc. 1994, 116, 3892-3900.

[36] a) V. Barone, M. Cossi, J. Phys. Chem. A 1998, 102, 1995-2001; b) M. Cossi, N. Rega, G. Scalmani, V. Barone, J. Comput. Chem. 2003, 24, 669-681.

[37] a) S. A. Bizzozero, H. Dutler, Bioorg. Chem. 1981, 10, 46-62; b) B. Liu C. J. Schofield, R. C. Wilmouth, J. Biol. Chem. 2006, 281, 24024-24035.

[38] M. Meot-Ner, J. Am. Chem. Soc. 1983, 105, 4906-4911.

[39] a) C. Lee, W. Yang, R. G. Parr, Phys. Rev. B: Condens. Matter 1988, 37, 785-789; b) A. D. Becke, Phys. Rev. A: Gen. Phys. 1988, 38, 3098-3100; c) A. D. Becke, J. Chem. Phys. 1992, 96, 2155-2160; d) A. D. Becke, J. Chem. Phys. 1992, 97, 9173-9177; e) A. D. Becke, J. Chem. Phys. 1993 , 98, 5648-5652.

[40] M. W. Schmidt, K. K. Baldridge, J. A. Boatz, S. T. Elbert, M. S. Gordon, J. H. Jensen, S. Koseki, N. Matsunaga, K. A. Nguyen, et al., J. Comput. Chem. 1993, 14, 1347-1363.

[41] R. Z. Liao, J. G. Yu, F. Himo, J Phys Chem B 2010, 114, 2533-2540.

[42] E. Krieger, T. Darden, S. B. Nabuurs, A. Finkelstein, G. Vriend, Proteins: Struct., Funct., Bioinf. 2004, 57, 678-683.

[43] A. Jakalian, D. B. Jack, C. I. Bayly, J. Comput. Chem. 2002, 23, 16231641 
[44] U. Essmann, L. Perera, M. L. Berkowitz, T. Darden, H. Lee, L. G. Pedersen, J. Chem. Phys. 1995, 103, 8577-8593.

Received: ((will be filled in by the editorial staff))

Published online: ((will be filled in by the editorial staff)) 


\section{FULL PAPER}

An increased reaction rate for lipase catalyzed $\mathrm{N}$-acylation of amino alcohols and related compounds compared to amines can be explained by a hydrogen shuttle mechanism that avoids nitrogen inversion in the transition state. Our suggested mechanism leads to the formation of a tetrahedral intermediate in a stereoelectronically favorable conformation for facile amide bond synthesis.

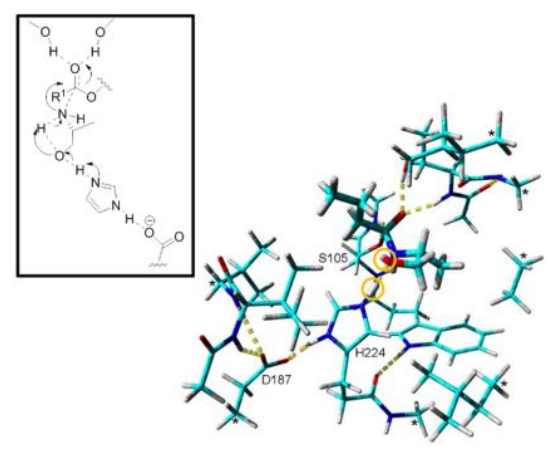

Per-Olof Syrén ${ }^{*}[a],[c]$, Florian Le Joubioux ${ }^{[b]}$, Yesmine Ben Henda ${ }^{[b]}$, Thierry Maugard ${ }^{[b]}$, Karl Hult $t^{[c]}$, Marianne Graber $^{*}[b]$

Page No. - Page No.

Proton shuttle mechanism in the transition state of lipase catalyzed $\mathrm{N}$ acylation of amino alcohols 


\section{Supporting Information}

\section{Proton shuttle mechanism in the transition state of}

\section{lipase catalyzed $\mathrm{N}$-acylation of amino alcohols}

Per-Olof Syrén ${ }^{*[a],[c]}$,Florian Le Joubioux ${ }^{[\mathrm{b}]}$, Yesmine Ben Henda ${ }^{[\mathrm{b}]}$, Thierry Maugard ${ }^{[\mathrm{b}]}$, Karl Hult $^{[\mathrm{c}]}$, Marianne Graber ${ }^{*}[\mathrm{~b}]$

[a] Dr. P.-O. Syrén, Institute of Technical Biochemistry, University of Stuttgart, Allmandring 31, D-70569 Stuttgart, Germany, Fax: (+49)-(0)711-685-63196, E-mail: per-olof.syren@itb.uni-stuttgart.de

${ }^{[b]}$ Prof. M. Graber, F. Le Joubioux, Y. Ben Henda, Prof. T. Maugard, UMR CNRS 6250 LIENSs, Université de La Rochelle, Bâtiment Marie Curie, Avenue Michel Crépeau, 17042 La Rochelle cedex 1, France, E-mail: mgraber@univ-Ir.fr

${ }^{[c]}$ Prof K. Hult, Department of biochemistry, School of biotechnology, Royal Institute of Technology, AlbaNova University Centre, SE-106 91 Stockholm, Sweden 
a

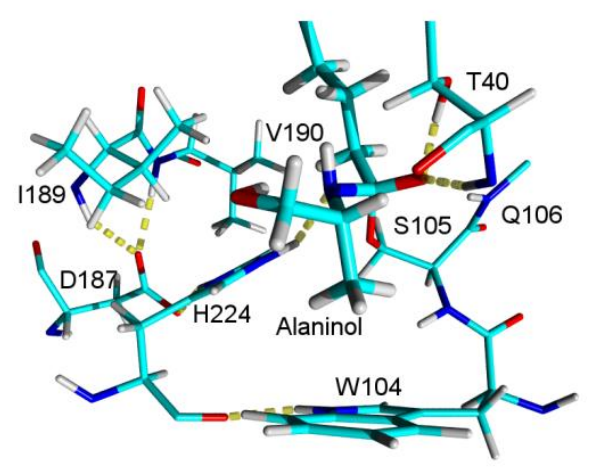

b

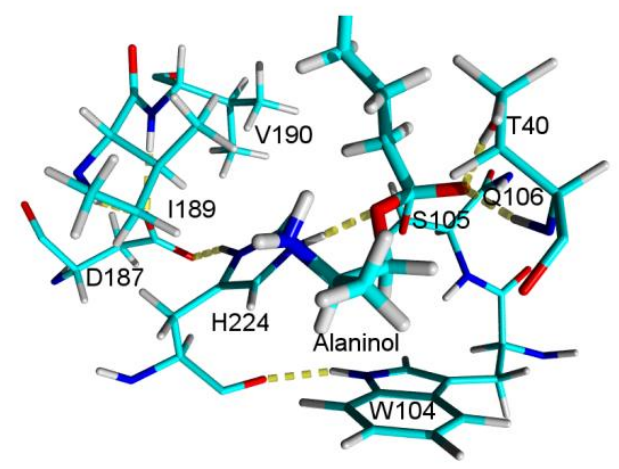

Figure S1. Snapshots from the molecular dynamics simulations of the tetrahedral intermediate representing transition state for acylation of $(R)$-alaninol using Candida antarctica lipase B. a) $N$-acylation of $(R)$-alaninol. b) A snapshot of $O$-acylation of $(R)$-alaninol is shown for comparison. The catalytic amino acids (S105, H224, D187) as well as oxyanion hole (T40 and Q106) are shown. W104 forms the bottom of the so called stereoselectivity pocket in Candida antarctica lipase B. Two amino acids, I189 and V190, were in close proximity to the substrate. $(R)$-Alaninol is shown as enlarged sticks. Color code: Cyan- carbon, Red - oxygen, Blue - nitrogen, White - hydrogen. Hydrogen bonds are indicated with dashed yellow lines.

Table S1. Average lengths and angles for the possible intramolecular hydrogen bonds formed in $(R)$-alaninol as given from MD-simulations of the tetrahedral intermediate representing the transition state for $\mathrm{N}$-acylation in Candida antarctica lipase B. ${ }^{[\mathrm{a}]}$

\begin{tabular}{|c|c|c|}
\hline Average distance $[\AA]$ & $\begin{array}{l}\text { Average angle } \\
\text { NH---O } \\
(\mathrm{OH}---\mathrm{N})^{[b]} \\
\text { [degrees] }\end{array}$ & $\begin{array}{l}\text { Average angle } \\
\text { H---OC } \\
(\mathrm{H}---\mathrm{NC})^{[\mathrm{b}]} \\
\text { [degrees] }^{-}\end{array}$ \\
\hline \multicolumn{3}{|c|}{$\mathrm{NH}$---O interaction in (R)-alaninol } \\
\hline 2.66 & 77 & 72 \\
\hline \multicolumn{3}{|l|}{$\begin{array}{l}\text { OH---N interaction in } \\
\text { (R)-alaninol }\end{array}$} \\
\hline 1.86 & 132 & 159 \\
\hline
\end{tabular}

[a] Based on 1.2 ns MD-simulation of the second tetrahedral intermediate. Values given are the average values for all 1160 snapshots generated in the simulation. [b] The atoms forming the two angles associated with the two possible hydrogen bonds, the NH---O hydrogen bond and the $\mathrm{OH}---\mathrm{N}$ hydrogen bond respectively. For the $\mathrm{OH}---\mathrm{N}$ interaction the relevant atoms forming the two angles are given in brackets. 
Table S2. Cost for nitrogen inversion starting from the various conformations of $N$-methyl alaninol based on B3LYP/6-311+G(2d,2p) single point calculations. Solvation was taken into account by using a polarizable continuum model (CPCM). The corresponding relative energies for $N$-methyl propylamine are given for reference.

\begin{tabular}{ll}
\hline Conformer & Cost for nitrogen inversion ${ }^{[\mathrm{a}]}[\mathrm{kcal} / \mathrm{mol}]$ \\
& In gas phase In chloroform $\begin{array}{l}\text { In 2-methyl-2- } \\
\text { butanol }\end{array}$ \\
\hline
\end{tabular}

\section{$(R)-N$-Methyl alaninol}<smiles>C[C@@H]1OC[C@H]1C</smiles><smiles>C[C@@H]1OC[C@H]1C</smiles><smiles>CN[C@@H](C)CO</smiles>

$\underline{N \text {-methyl propylamine }}$

\begin{tabular}{llll} 
& & & \\
NHMe & 2.1 & 3.2 & 3.2 \\
\hline
\end{tabular}

${ }^{[a]}$ The cost for nitrogen inversion is given as the energy difference between the TS for nitrogen inversion and the corresponding ground state conformer. Relative energies are based on B3LYP/6-311+G(2d,2p) single point calculations and includes ZPVE. The corresponding relative energies were calculated in the gas phase, in chloroform and in 2-methyl-2-butanol for comparison. 


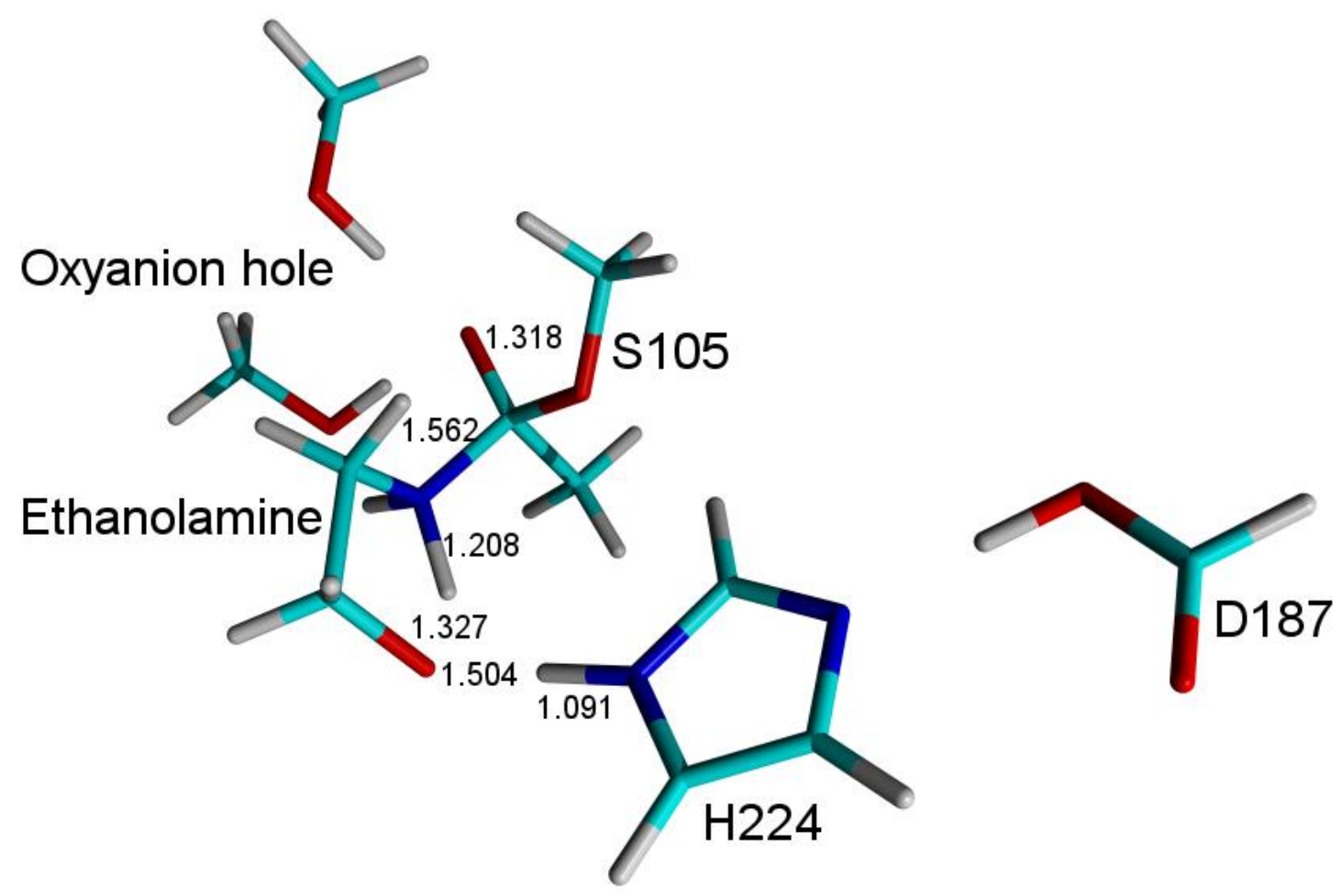

Figure S2. The transition state for $N$-acylation of ethanol amine in a small ab initio model of a serine hydrolase catalytic machinery calculated using DFT at the B3LYP/6-31G(d,p) level of theory. Nucleophilic attack was concomitant with the transfer of two protons. The bond lengths (l) of the bonds being formed/broken in the transition state are given in $\AA$. The proton donated by the $\mathrm{NH}_{2}$-group of the amino alcohol is shared between the nitrogen and oxygen of the amino alcohol $(\mathrm{l}=1.208 \AA$ and $\mathrm{l}=1.327 \AA$ respectively) whereas the hydroxyl proton is almost completely transferred to the enzyme catalytic base $(l=1.504 \AA)$. Methyl acetate was chosen to represent the acyl enzyme and ethanol amine was chosen to represent an amino alcohol. The catalytic triad was represented by a methanol molecule, an imidazole molecule and a formate ion. The oxyanion hole was represented by two methanol molecules. The corresponding residue numbers of amino acids in the active site of Candida antarctica lipase B are given. In total the small quantum model consisted of 47 atoms and the activation energy in the gas phase for the proton shuttle of $N$-acylation was $14.8 \mathrm{kcal} / \mathrm{mol}$ including ZPVE. The transition state had one imaginary frequency of $742.4 \mathrm{i} \mathrm{cm}^{-1}$ that corresponded to nucleophilic attack coincidently with the transfer of two protons. 


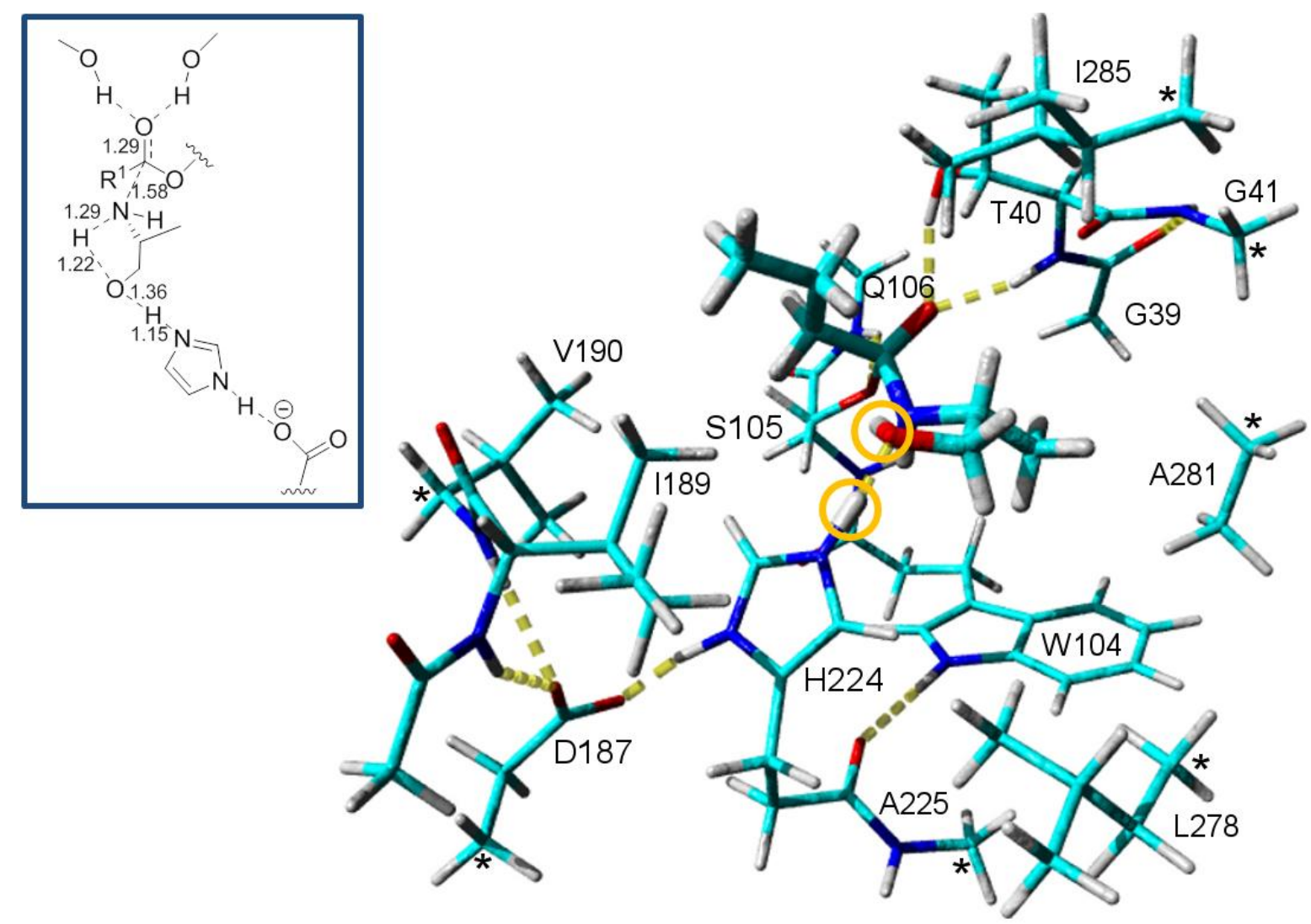

Figure S3. The large active site model of Candida antarctica lipase B with the calculated transition state structure for the proton shuttle mechanism of $N$-acylation of $(R)$-alaninol. The two protons encircled are being transferred in TS coincidently with nucleophilic attack. Relevant distances of bonds being formed/broken in TS are shown within the blue frame. Our large model of the active site, used for the $\mathrm{B} 3 \mathrm{LYP} / 6-31 \mathrm{G}(\mathrm{d}, \mathrm{p})$ ab initio calculations, consisted of 205 atoms and included the side chains of G39, T40, G41, W104, S105, Q106, D187, I189, V190, H224, A225, L278, A281 and I285. The acyl enzyme with the carbon chain originating from the acyl donor (containing four carbon atoms in our model) and the substrate, $(R)$-alaninol are shown in enlarged sticks. Atoms shown with an asterisk were kept fixed during the simulations since they correspond to backbone atoms in the protein that does not have the ability to move freely. This is a standard technique in cluster ab initio calculations with the effect that a number of small imaginary frequencies are introduced (typically in the order of $30 \mathrm{i} \mathrm{cm}{ }^{-1}$ ). These small imaginary frequencies have a neglectable effect on the energy of the system. The reaction path for the proton shuttle mechanism, obtained by computation of the intrinsic reaction coordinate (IRC), is attached as a Shockwave Flash movie (see the Shockwave Flash movies section).

Color code: Cyan- carbon, Red - oxygen, Blue - nitrogen, White - hydrogen. Hydrogen bonds are indicated with dashed yellow lines. 

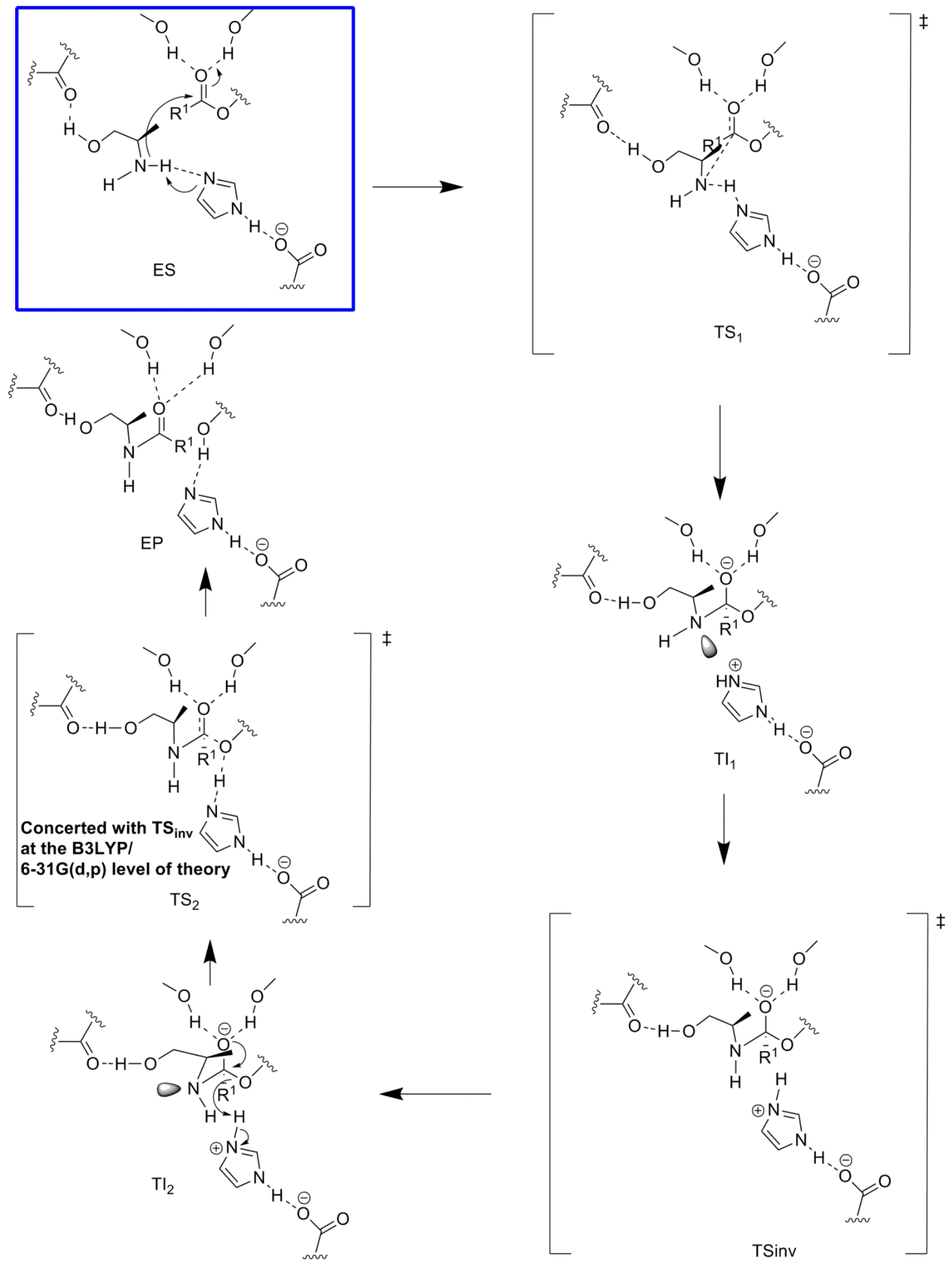

Figure S4. Schematic illustration of the "traditional" mechanism for lipase catalysed $N$-acylation of $(R)$-alaninol for which proton shuttling does not occur. Note that this hypothetical mechanism uses the open chain of the amino alcohol substrate. This traditional mechanism requires the intramolecular hydrogen bonding pattern to be broken, whereas it is known that amino alcohols adopt conformations with an intramolecular hydrogen bond ${ }^{[1]}$ 
By performing ab initio calculations for the hypothetical traditional mechanism of $N$-acylation of an amino alcohol, the catalytic effect of our suggested proton shuttle (Figure S5) can be assessed by comparison of the activation barriers for the respective mechanism. In the traditional mechanism, the open chain conformation of $(R)$-alaninol, for which proton shuttling can not occur, becomes $N$-acylated. As shown in the figure, the hydroxyl of the amino alcohol can form a hydrogen bond to the backbone of T40 in the enzyme active site and this interaction was formed upon minimization of the open chain conformation in the enzyme active site. Therefore we used this particular conformation for the ab initio calculations for the hypothetical traditional mechanism using the large active site model. The calculated energy difference between the ES-complex containing the open chain (shown in the blue frame in the figure) and the corresponding ES-complex for the proton shuttle mechanism, that contains an intramolecular hydrogen bond, was $3 \mathrm{kcal} / \mathrm{mol}$ at the B3LYP/6-31G(d,p) level and in favour of the ES-complex for the traditional mechanism. The corresponding hydrogen bond to the backbone of T40 was also found to be formed for the corresponding traditional mechanism of $O$-acylation with the amino group functioning as hydrogen bond donor. In this case a larger energy difference of $6 \mathrm{kcal} / \mathrm{mol}$ was found between the corresponding ES-complexes (between the ES-complex for "traditional" $O$-acylation, which was lower in energy, and the ES-complex for a proton shuttle mechanism involving $O$-acylation). The hydrogen bond that we modelled to the backbone of T40 for the hypothetical traditional mechanism of $N$-acylation does not contribute to catalysis $\left(k_{\text {cat,app }}\right)$ since the hydrogen bond is already fully developed in the ES-complex. Thus this interaction is not involved in increasing the $k_{c a t, a p p}$-values for $N$-acylation of amino alcohols or in favouring $N$ acylation over $O$-acylation. It replaces the interaction formed between the hydroxyl and the $\mathrm{N}_{\varepsilon 2}$ of His 224 in the ES-complex for the proton shuttle mechanism of $N$-acylation (Figure S5). Further the calculated barrier of activation for the traditional mechanism for $N$-acylation of $(R)$-alaninol was not lower than the corresponding calculated barrier using isopropylamine as nucleophile for which the hydrogen bond to the backbone of T40 can not form. Finally methoxy-2-propylamine displays an enhanced $k_{\text {cat app }}$ for $N$-acylation but lacks the possibility of hydrogen bond formation to the backbone of T40.

\section{Clarification of transition states and intermediates:}

In the ES-complex (within the blue frame), the amino alcohol is complexed to the acyl enzyme. In the first transition state $\left(\mathrm{TS}_{1}\right)$ the nitrogen of the amino alcohol attacks the acyl enzyme and a proton sitting on the nitrogen is being abstracted by the enzyme catalytic base. In the first tetrahedral intermediate formed $\left(\mathrm{TI}_{1}\right)$, the lone pair of the scissile nitrogen atom is pointing towards the enzyme catalytic base. Nitrogen inversion ( $\left.\mathrm{TS}_{\text {inv }}\right)$ breaks the hydrogen bond between the scissile nitrogen atom and the catalytic histidine which causes the histidine to move towards the catalytic serine (this is clarified in the attached Shockwave Flash movies of the computed intrinsic reaction coordinate in the large active site model, see the Shockwave Flash movies section). After the inversion, the nitrogen lone pair now points antiperiplanar to the Ser $\mathrm{O}_{\gamma}$-former carbonyl carbon bond in the second tetrahedral intermediate $\left(\mathrm{TI}_{2}\right)$. This orientation of the nitrogen lone pair corresponds to the stereoelectronically favourable conformation for amide bond formation/breakdown in accordance with Deslongchamps stereoelectronic theory. ${ }^{[2]} \mathrm{TS}_{2}$ denotes the transition state for amide bond formation. It should be emphasized that depending on the level of theory used, nitrogen inversion is either a separate TS (which was the case when using HF/6-31G(d,p) and the large active site model containing 205 atoms) or concerted with amide bond formation, which was found to be the case at the B3LYP/6-31G(d,p) level of theory in the large active site model. Interestingly, the same result is obtained for the small serine hydrolase active site model presented in Figure S2 for which nitrogen inversion was found to be a separate transition state from amide bond synthesis at the HF/6-31G(d,p) level of theory as well as at the MP2/6-31G(d,p) level of theory (the size of the large active site model of 205 atoms prohibited an MP2 analysis in the large model). Again nitrogen inversion was found to be concerted with amide bond synthesis at the B3LYP/6-31G(d,p) level of theory. These findings are clarified in the attached Shockwave Flash movies of the reactions paths obtained by computation of the intrinsic reaction coordinate in the small active site model, see the Shockwave Flash movies section. We conclude that nitrogen inversion constituted the rate limiting transition state for the traditional mechanism in the large active site model (Figure S7). Nitrogen inversion has previously been found to be rate limiting by using MP2/6-311+G(2d,2p) calculations in a small active site model. ${ }^{[3]}$ At the B3LYP/6-31G(d,p) level, the inversion step that occurs in order to avoid having the nitrogen lone pair in a stereoelectronically "forbidden" conformation, is concerted with amide bond synthesis. 
EP represents the product amide complexed to the enzyme active site. $\mathrm{R}^{1}=\mathrm{C}_{3} \mathrm{H}_{7}$ in the large active site model used for the $a b$ initio calculations. 


\section{$N$-acylation of $(R)$-alaninol, proton shuttle mechanism}<smiles></smiles><smiles>CC1CN2CC(C)C(N2)O1</smiles>

ES
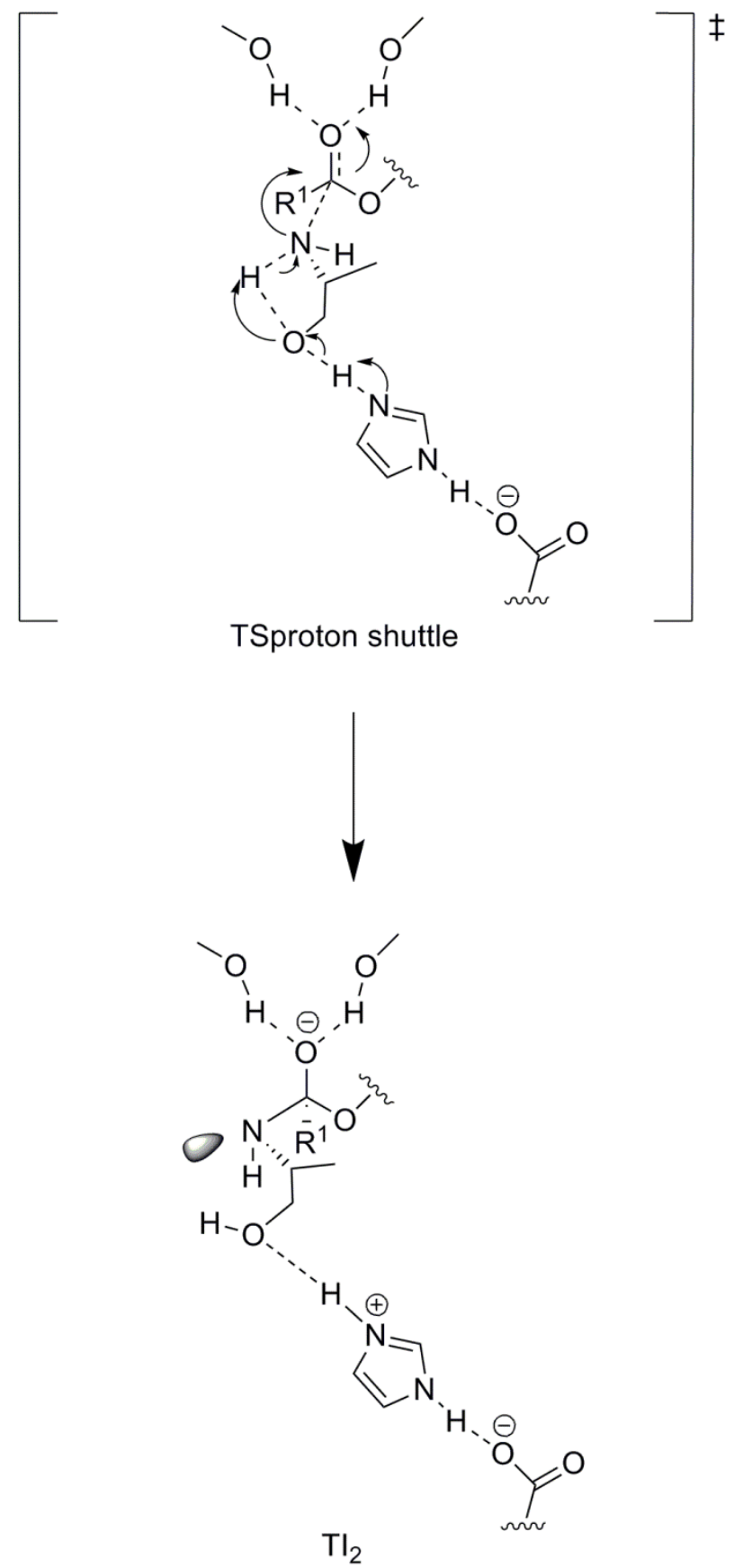

Figure S5. Schematic illustration of our suggested proton shuttle mechanism for lipase catalysed $N$-acylation of $(R)$-alaninol. Nucleophilic attack coincidently with the transfer of two protons in transition state $\left(\mathrm{TS}_{\text {proton shutle }}\right)$ leads directly to the formation of a tetrahedral intermediate $\left(\mathrm{TI}_{2}\right)$ for which the lone pair of the nitrogen atom is in a stereoelectronically favourable conformation for amide bond formation. For the proton shuttle mechanism, nitrogen inversion is thus obsolete as opposed to the traditional reaction mechanism (Figure $\mathrm{S} 4$ ). $\mathrm{R}^{1}=\mathrm{C}_{3} \mathrm{H}_{7}$ in the large active site model used for the $a b$ initio calculations. 


\section{$O$-acylation of $(R)$-alaninol, proton shuttle mechanism}
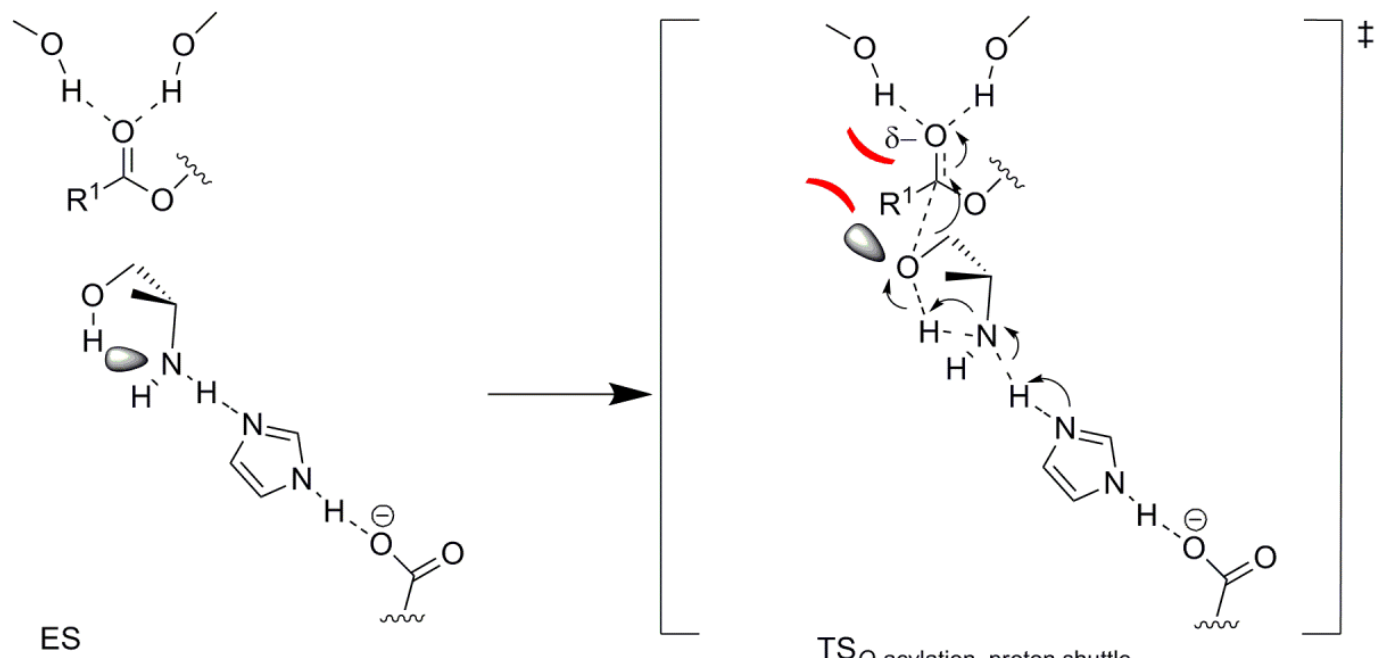

TS $_{\text {O-acylation, proton shuttle }}$

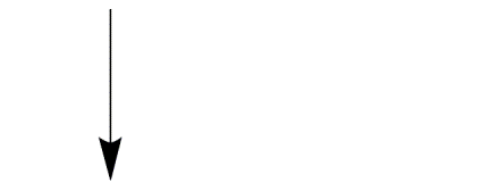

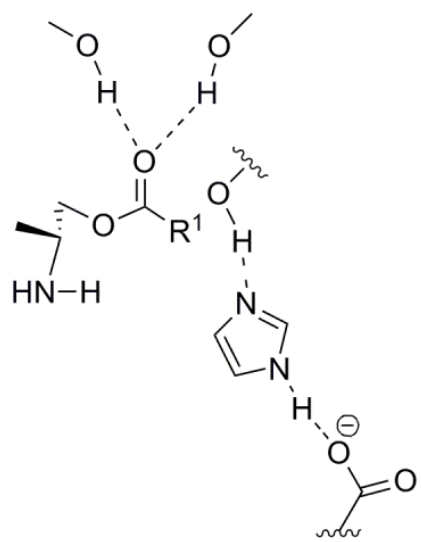

EP

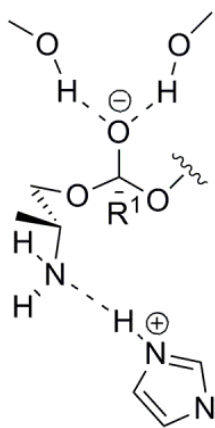

$\mathrm{TI}$<smiles>CC(C)C(=O)O</smiles>
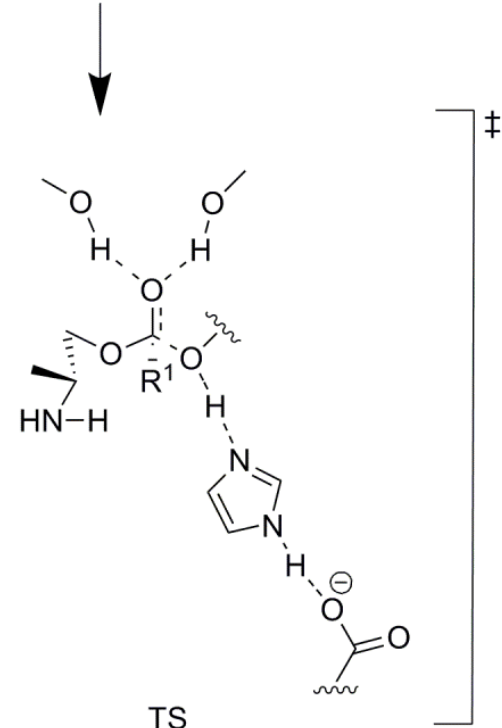

Figure S6. Proton shuttle mechanism for enzyme catalyzed $O$-acylation of $(R)$-alaninol. The preference of amino alcohols to form intramolecular hydrogen bonds makes $(R)$-alaninol adopting a conformation that is 
preorganized for a proton shuttle mechanism. By inspection of Figure S6 it is seen that for the proton shuttle involving $O$-acylation, a very unfavourable interaction between the oxygen (free) lone pair and the (developing) negative charge on the carbonyl oxygen of the acyl enzyme is present in transition state (illustrated by red arcs). The other possibility is an unfavourable interaction with a lone pair of the Ser105 $\mathrm{O} \gamma$. This fact makes the proton shuttle for $O$-acylation unfavourable compared to the proton shuttle mechanism for $N$-acylation where a proton sitting on the nitrogen occupies the corresponding position in TS (Figure S5). The single lone pair on the scissile nitrogen atom is involved in the proton shuttle mechanism for $\mathrm{N}$-acylation and a stereoelectronically favourable intermediate for amide bond synthesis is formed (Figure S5). For the proton shuttle involving $O$-acylation one lone pair does not participate in the proton shuttling and adopts a very unfavourable position for the mechanism to occur. This conformation is imposed by the positioning of the enzyme catalytic base (H224) which is the acceptor in the proton shuttle. Furthermore, for the proton shuttle for $O$-acylation a stable $-\mathrm{OH}---\mathrm{N}$ hydrogen bond in the ES-complex is replaced by a less stable -NH---O interaction in the tetrahedral intermediate (TI) upon crossing the transition state for the proton shuttle mechanism $\left(\mathrm{TS}_{O \text {-acylation, proton shuttle }}\right)$. This fact also increases the barrier of activation for the proton shuttle mechanism involving $O$-acylation as compared to the corresponding proton shuttling for $\mathrm{N}$-acylation (Figure S5). It should be noted that the very unfavourable interaction in TS does not occur for $O$-acylation of an alcohol that reacts through an open chain conformation since the catalytic histidine now adopts its normal position where a hydrogen bond is formed directly with the hydroxyl proton.

The tetrahedral intermediate (TI) decomposes to the product ester complexed to the active site (EP) after crossing the transition state labelled TS in the figure. 


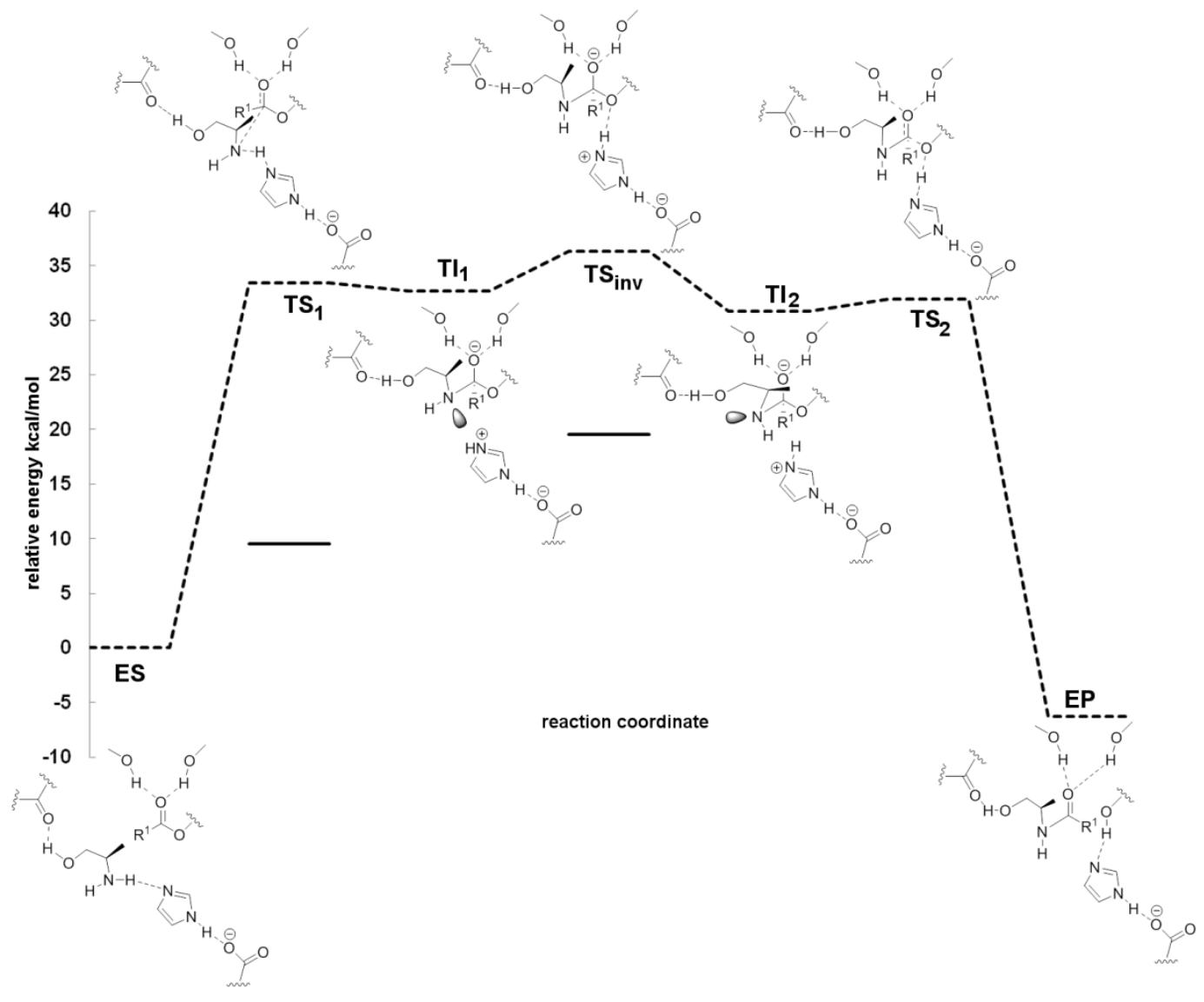

Figure S7. Strategy for the cluster ab initio calculations with results using HF/6-31G(d,p) and DFT at the B3LYP/6-31G(d,p) level shown for the traditional mechanism with structures of transition states and intermediates schematically drawn. By having a large model of the active site (205 atoms), calculations are tedious and time consuming. Therefore it is advantageous to optimize geometries and transition states using a lower level of theory initially (i.e. HF) and then use the obtained structures as starting point for optimization at the higher level of theory (in this case DFT at the B3LYP/6-31G(d,p) level). The whole reaction mechanism was calculated first by using $\mathrm{HF} / 6-31 \mathrm{G}(\mathrm{d}, \mathrm{p})$ (energies of transition states and intermediates according to the dotted line). Starting from the HF/6-31G(d,p) optimized structures, the mechanism was then refined using B3LYP/6$31 \mathrm{G}(\mathrm{d}, \mathrm{p})$ (energy levels of transition states shown by solid lines). We conclude that the rate limiting transition state for $N$-acylation is nitrogen inversion $\left(\mathrm{TS}_{\mathrm{inv}}\right)$ for both $\mathrm{HF}$ and B3LYP. In the transition state for nitrogen inversion, the nitrogen atom is $\mathrm{sp}^{2}$-like (see figure $\mathrm{S} 4$ for more details on the reaction mechanism). Note that at the B3LYP/6-31G(d,p) level of theory, the TS for nitrogen inversion is concerted with amide bond formation $\left(\mathrm{TS}_{2}\right)$ and thus at this level the product amide is formed directly. The large quantum model consisting of 13 residues (205 atoms) of the active site of Candida antarctica lipase B was used for the calculations (the model is shown in Figure S3). In Figure 2 the proton shuttle mechanism of $N$-acylation is compared with the traditional mechanism. 


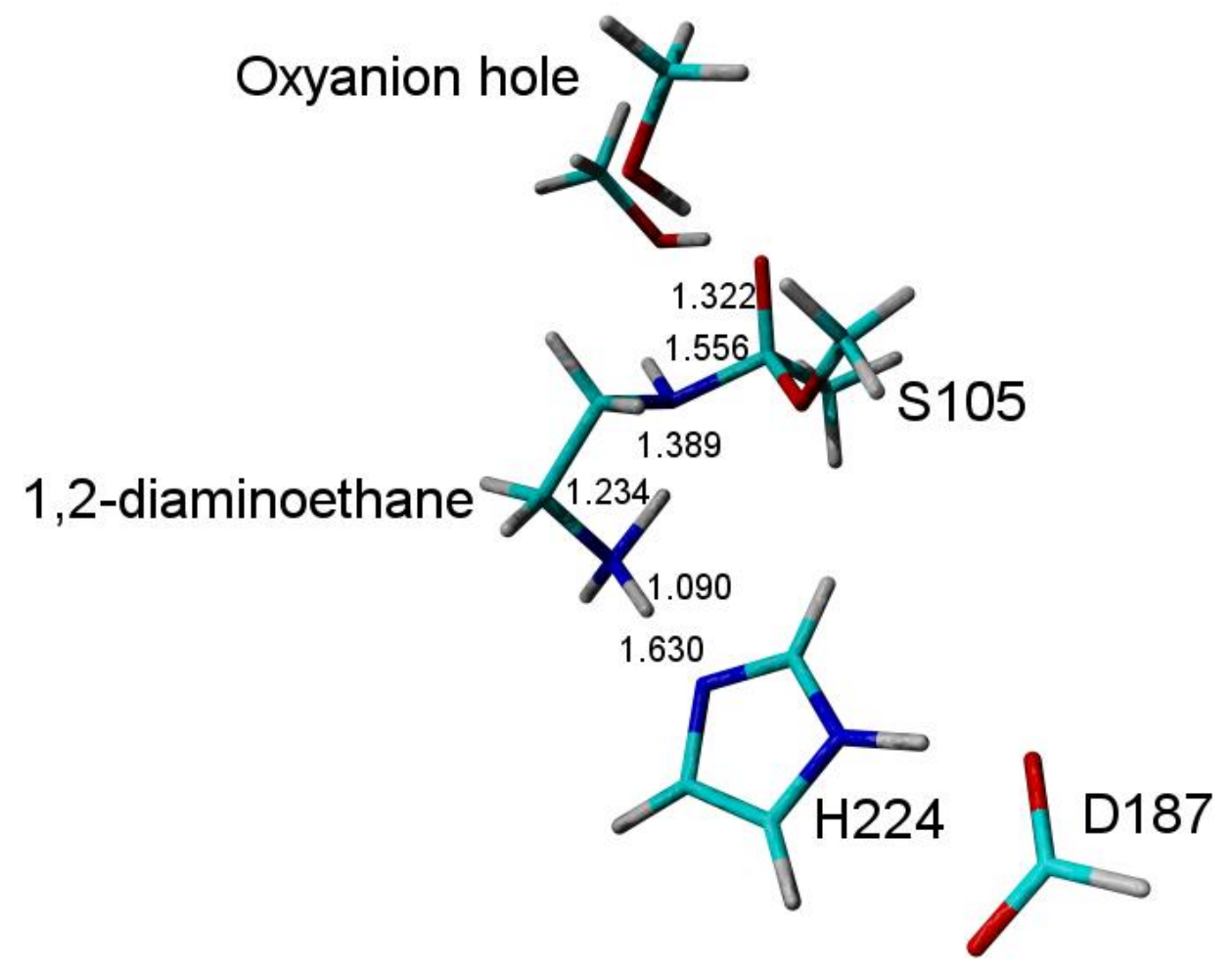

Figure S8. The transition state for the proton shuttle mechanism of $N$-acylation of 1,2-diaminoethane in a small $a b$ initio model of a serine hydrolase catalytic machinery calculated using DFT at the B3LYP/6-31G $(\mathrm{d}, \mathrm{p})$ level of theory. Nucleophilic attack was concomitant with the transfer of two protons. The bond lengths (1) of the bonds being formed/broken in the transition state are given in $\AA$. Methyl acetate was chosen to represent the acyl enzyme and 1,2-diaminoethane was chosen to represent a diamine. The catalytic triad was represented by a methanol molecule, an imidazole molecule and a formate ion. The oxyanion hole was represented by two methanol molecules. The corresponding residue numbers of amino acids in the active site of Candida antarctica lipase B are given. In total the small quantum model consisted of 48 atoms and the activation energy in the gas phase for the proton shuttle of $N$-acylation was $15.7 \mathrm{kcal} / \mathrm{mol}$ including ZPVE. The transition state had one imaginary frequency of $946.3 \mathrm{i} \mathrm{cm} \mathrm{cm}^{-1}$ that corresponded to nucleophilic attack coincidently with the transfer of two protons. 


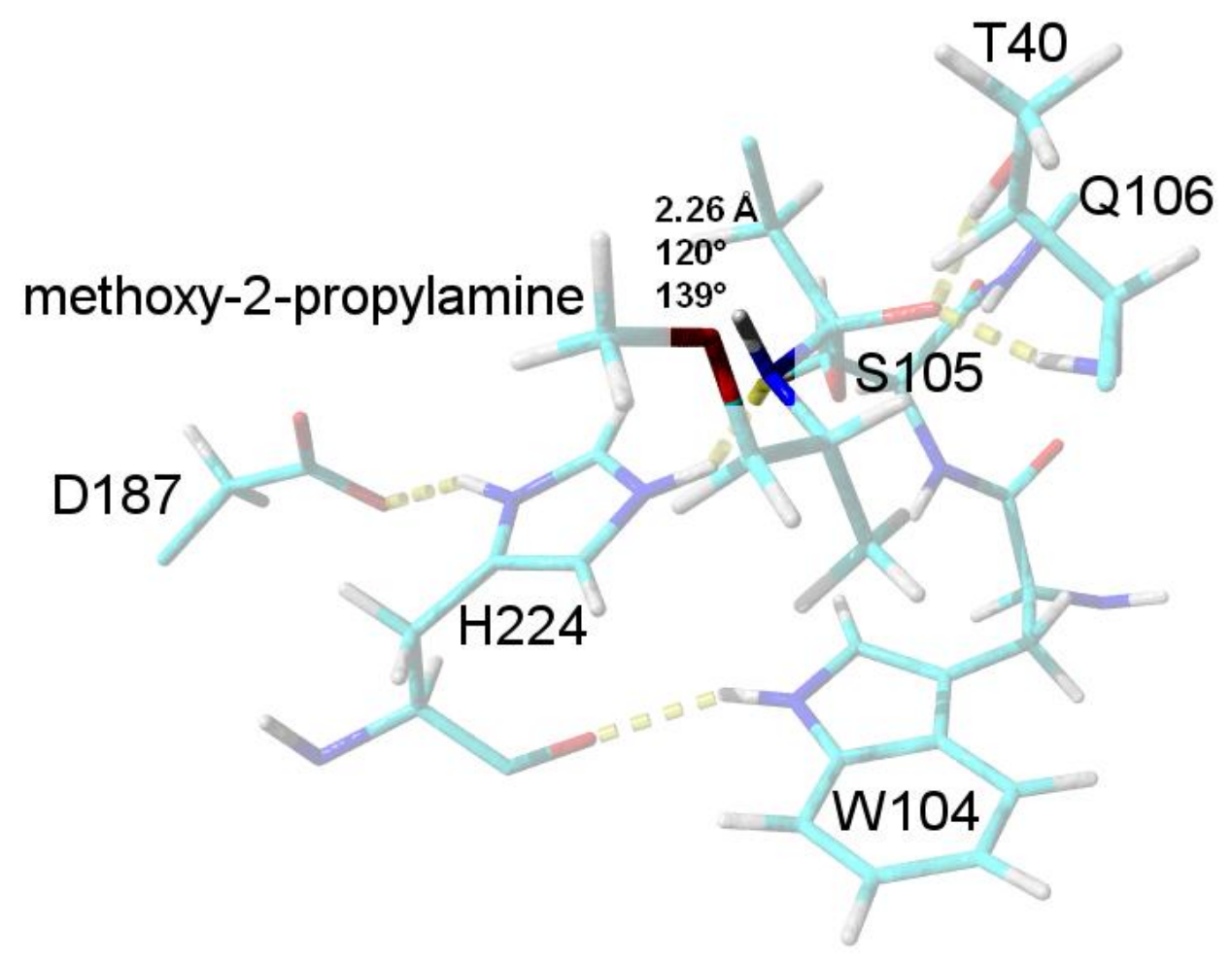

Figure S9. This figure shows a snapshot from the MD-simulation of the second tetrahedral intermediate representing the transition state for enzyme catalyzed $N$-acylation of methoxy-2-propylamine. The substrate ether oxygen (highlighted) was found to be close to the scissile NH-group (shown in highlighted sticks) throughout the $1 \mathrm{~ns}$ MD-simulation which shows that the proton is in a good position for transfer by a proton shuttle mechanism. The distance $(2.26 \AA)$ and the relevant angles $\left(120^{\circ}\right.$ and $\left.139^{\circ}\right)$ for the hydrogen bond donated by the scissile NH-group and accepted by the ether oxygen are given in the figure. The catalytic amino acids (S105, H224, D187) as well as the oxyanion hole (T40 and Q106) are shown. W104 forms the bottom of the so called stereoselectivity pocket in Candida antarctica lipase B. Color code: Cyan- carbon, Red - oxygen, Blue - nitrogen, White - hydrogen. Hydrogen bonds are indicated with dashed yellow lines. 


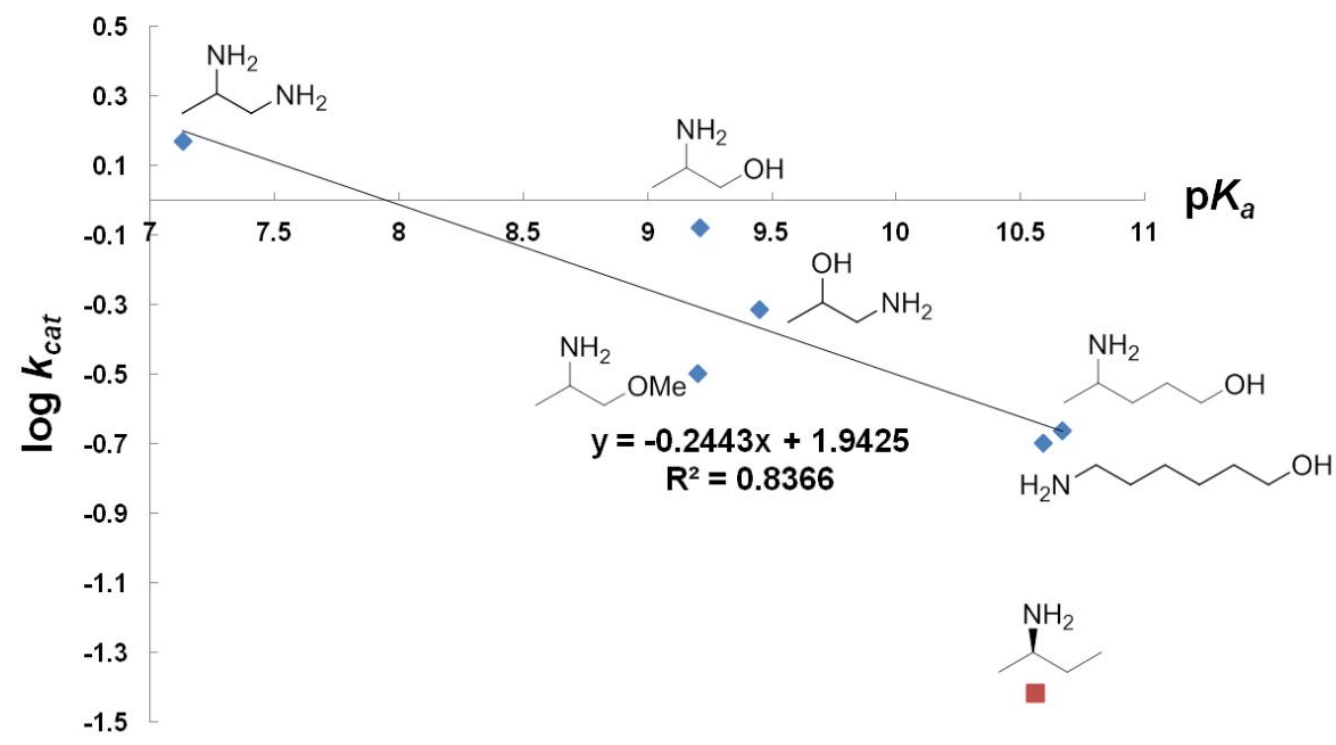

Figure S10. Linear Free Energy Relationship (LFER) analysis based on experimental $k_{\text {cat }}$ values for enzyme catalyzed $N$-acylation (Table 1). The difunctionalized amines (blue diamonds) follow the same trend of $\log k_{\text {cat }}$ as a function of $\mathrm{p} K_{a}$ indicating that they share the same reaction mechanism. (R)-2-butylamine (red square) do not follow the same trend and reacts differently (through nitrogen inversion). The moderate slope of -0.24 is consistent with partial proton transfer in the rate limiting transition state which is in accordance with our suggested proton shuttle mechanism. Such partial proton transfer from the scissile NH-group in the rate limiting transition state does not occur for the "traditional" reaction mechanism involving nitrogen inversion. The $\mathrm{p} K_{a}$ values were taken from the literature. ${ }^{[4]}$ 


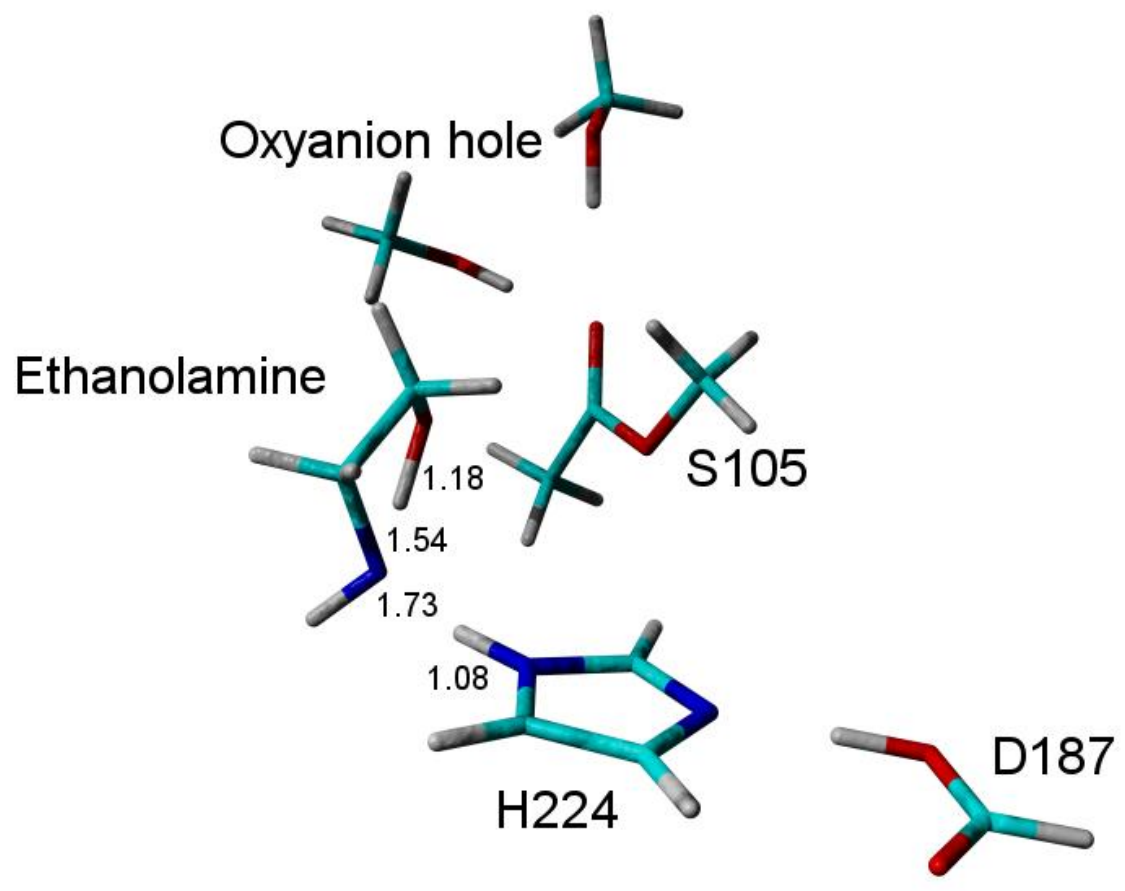

Figure S11. The proton shuttle for $O$-acylation of ethanol amine in a small ab initio model of a serine hydrolase catalytic machinery calculated at the B3LYP/6-31G(d,p) level of theory. Two protons are transferred in the transition state model. The distance between the hydroxyl oxygen of ethanol amine and the carbonyl carbon of the acyl enzyme in this transition state model is $2.64 \AA$, which is significantly longer than for $N$-acylation for which the corresponding distance was $1.56 \AA$ (Figure S2). The bond lengths (l) of the bonds being formed/broken in the transition state model are given in $\AA$. Methyl acetate was chosen to represent the acyl enzyme and ethanol amine was chosen to represent an amino alcohol. The catalytic triad was represented by a methanol molecule, an imidazole molecule and a formate ion. The oxyanion hole was represented by two methanol molecules. The corresponding residue numbers of amino acids in the active site of Candida antarctica lipase B are given. In total the small quantum model consisted of 47 atoms and the activation energy in the gas phase for the proton shuttle involving $O$-acylation was $26 \mathrm{kcal} / \mathrm{mol}$ including ZPVE. The transition state model had one imaginary frequency of $946 \mathrm{icm}^{-1}$ that corresponded to the transfer of two protons and the nucleophilic oxygen approaching the carbonyl carbon. Despite many attempts, we were not able to fully relax the TS-model. By following one direction of the (imaginary) normal mode in an IRC run, the ES-complex was reached. However, in the other direction the energy increased. We were not able to relax the TS model using MP2/6$31 \mathrm{G}(\mathrm{d}, \mathrm{p})$. However, by using HF/6-31G(d,p) the proton shuttle mechanism for $O$-acylation was found to be stepwise with an alkoxy intermediate generated by the proton shuttle (this intermediate was not viable using MP2 or DFT). B3LYP/6-31G(d,p) single point calculations on the HF generated structures resulted in an activation barrier for the proton shuttle of $O$-acylation of $21 \mathrm{kcal} / \mathrm{mol}$. We conclude that the proton shuttle for $O$ acylation is more difficult than the corresponding shuttle for $N$-acylation (Figure S2, Figure S13) and thus provides no advantage for $O$-acylation. 


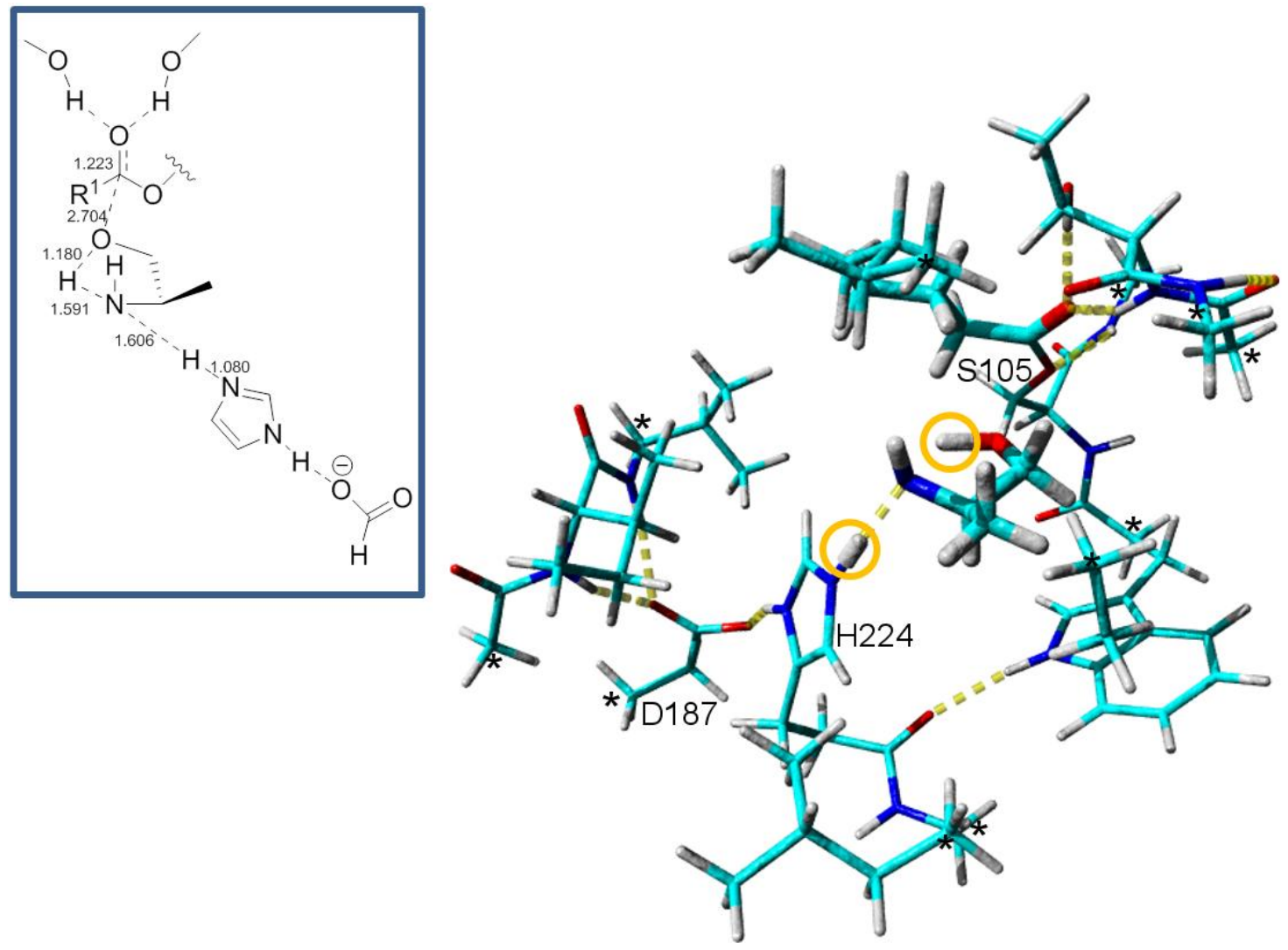

Figure S12. The structure of the calculated transition state model for the proton shuttle mechanism of $O$ acylation of $(R)$-alaninol obtained at the B3LYP/6-31G(d,p) level. The two protons encircled are being transferred in the TS. Relevant distances of bonds being formed/broken in the TS are shown within the blue frame. Note the longer distance between the nucleophile and the carbonyl carbon $(2.7 \AA)$ as compared to the proton shuttle mechanism of $N$-acylation (1.6 $\AA$, Figure $\mathrm{S} 3$ ). This long distance is caused by an unfavourable interaction between the remaining lone pair of the amino alcohol oxygen and the lone pair on the $\mathrm{Ser} 105 \mathrm{O}_{\gamma}$ oxygen and/or the developing negative charge on the carbonyl oxygen in TS. The model of the TS structure could not be fully relaxed and a constrained optimization was performed in which the hydroxyl O-H bond length was set to $1.18 \AA$ and the $\mathrm{His} \mathrm{N}_{\varepsilon 2}-\mathrm{H}$ distance was set to $1.08 \AA$. These values were chosen based on using the small active site model that consisted of 47 atoms. The TS model for the proton shuttle involving $O$-acylation had an energy that was $39 \mathrm{kcal} / \mathrm{mol}$ higher than the corresponding ES-complex (B3LYP/6-31G(d,p)). We also optimized the corresponding structures using $\mathrm{HF} / 6-31 \mathrm{G}(\mathrm{d}, \mathrm{p})$ with the difference that the His $\mathrm{N}_{\varepsilon 2}-\mathrm{H}$ distance was not constrained. This resulted in a barrier that was $10 \mathrm{kcal} / \mathrm{mol}$ higher than for $N$-acylation at the $\mathrm{HF} / 6-31 \mathrm{G}(\mathrm{d}, \mathrm{p})$ level. We conclude that a proton shuttle involving $O$-acylation is more difficult than for $N$-acylation, which is unfavourable for $O$-acylation since the amino alcohol substrate is preorganized for such proton shuttling to occur.

The acyl enzyme with the carbon chain originating from the acyl donor (containing four carbon atoms in our model) and the substrate, $(R)$-alaninol are shown in enlarged sticks. Atoms shown with an asterisk were kept fixed during the simulations since they correspond to backbone atoms in the protein that does not have the ability to move freely. This is a standard technique in cluster $a b$ initio calculations with the effect that a number of small imaginary frequencies are introduced (typically in the order of $30 \mathrm{i} \mathrm{cm}^{-1}$ ). These small imaginary frequencies have neglectable effects on the energy of the system.

Color code: Cyan- carbon, Red - oxygen, Blue - nitrogen, White - hydrogen. Hydrogen bonds are indicated with dashed yellow lines. 


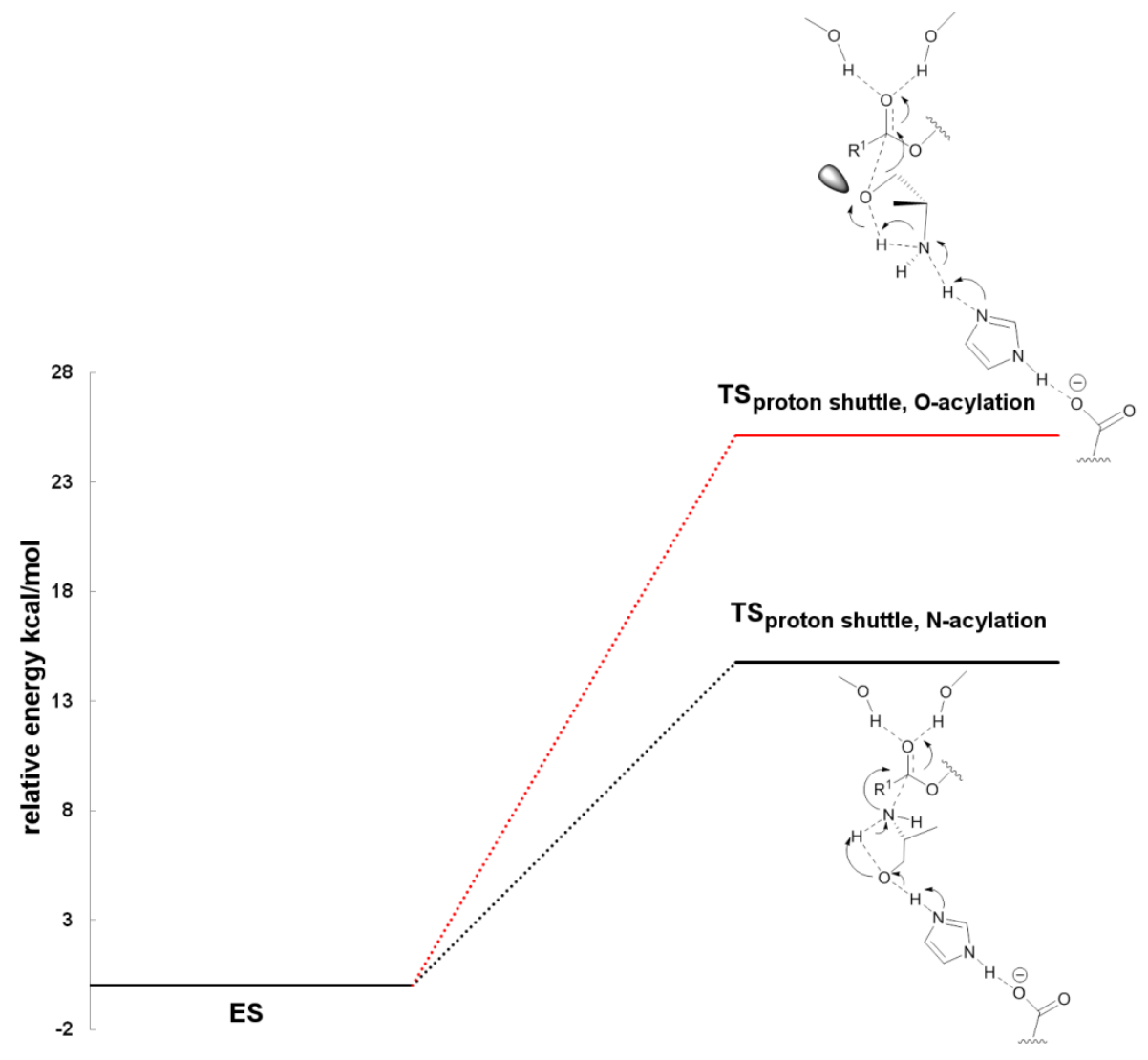

Figure S13. Energy profile diagram for proton shuttles calculated in the small active site model of a serine hydrolase consisting of 47 atoms (the model was introduced in Figure S2). In principle, a proton shuttle coincidently with nucleophilic attack, could be possible both for $N$-acylation and $O$-acylation of amino alcohols. The barrier for the proton shuttle involving $N$-acylation of $(R)$-alaninol was found to be $14.8 \mathrm{kcal} / \mathrm{mol}$ in the gas phase including ZPVE using B3LYP/6-31G(d,p). The relative energy of the TS for the proton shuttle involving $O$-acylation (red line) was found to be much higher and we estimate the barrier to be $25 \mathrm{kcal} / \mathrm{mol}$ in the gas phase including ZPVE using B3LYP/6-31G(d,p). As discussed in Figure S11 we did not manage to relax the TS structure completely but we conclude that the barrier for the proton shuttle involving $O$-acylation is much higher than for $N$-acylation. The reason for this is that the lone pair of the oxygen points towards the carbonyl oxygen of the acyl enzyme that becomes negatively charged in the TS, which causes the distance of the nucleophilic oxygen-carbonyl carbon to increase significantly in TS (Figure S11-S12). 


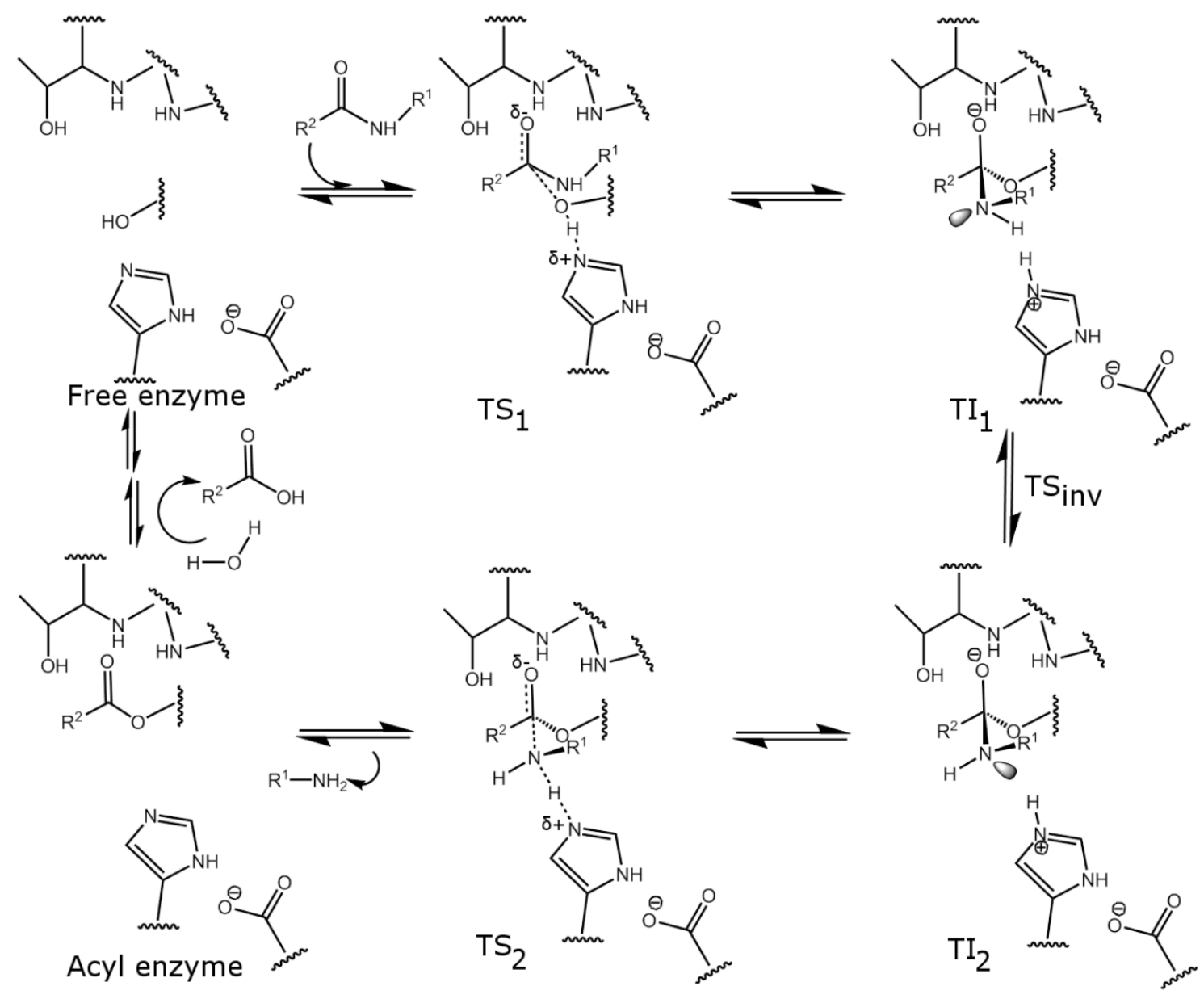

Figure S14. Reaction mechanism for amide bond hydrolysis catalyzed by Candida antarctica lipase B with transition states and intermediates schematically shown. The oxyanion hole is composed of T40 and Q106 in Candida antarctica lipase B and the residues S105, H224 and D187 form the catalytic triad. The amide substrate binds in to the free enzyme (top left) and after productive binding, the first transition state $\left(\mathrm{TS}_{1}\right)$ is reached which involves proton transfer from S105 to the catalytic base and nucleophilic attack on the carbonyl carbon. The produced tetrahedral intermediate $\left(\mathrm{TI}_{1}\right)$ has the lone pair pointing away from the catalytic base. In this conformation the scissile nitrogen is unable to accept a proton from the catalytic base (H224). Nitrogen inversion (or rotation) occurs and the second tetrahedral intermediate $\left(\mathrm{TI}_{2}\right)$ is produced which can proceed to the second transition state. In the second transition state $\left(\mathrm{TS}_{2}\right)$ the catalytic base donates a proton to the scissile nitrogen and the $\mathrm{C}-\mathrm{N}$ bond breaks, forming the acyl enzyme. A water molecule functions as nucleophile during the deacylation step which proceeds through two transition states and one tetrahedral intermediate. Hydrogen bonds are indicated with dashed lines. Note that as discussed previously, at the B3LYP/6-31G(d,p) level of theory, nitrogen inversion is concerted with nucleophilic attack $\left(\mathrm{TS}_{1}\right.$, or amide bond synthesis in the reverse direction). 


\section{Supplementary Note on acyl migration}

Scheme S1. The hypothetical lipase catalyzed $O$-acylation of an amino alcohol followed by chemical catalyzed $O$ - to $\mathrm{N}$-acyl migration. $\mathrm{HO}-\mathrm{R}^{2}-\mathrm{NH}_{2}$ corresponds to an arbitrary amino alcohol. The $O$-acylated intermediate is labeled and $\mathrm{E}$ indicates the enzyme.

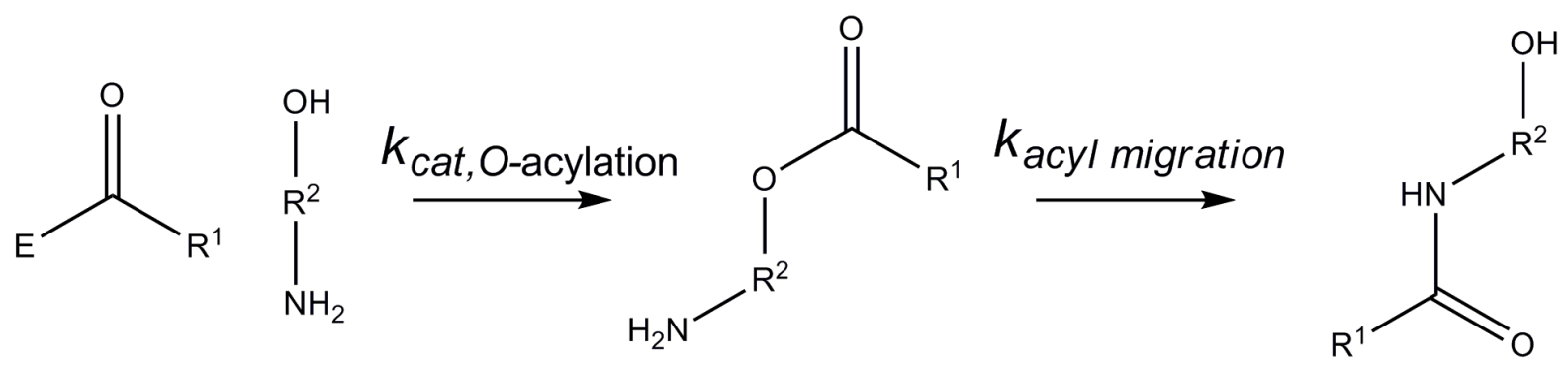

\section{Intermediate}

The steady-state concentration of the mono $O$-acylated intermediate can be calculated from:

$V_{\text {O-acylation }}-k_{\text {acyl migration }} *[$ Intermediate $]=0$

where the intermediate refers to the $O$-acylated intermediate from which $O$ - to $N$-acyl migration would occur. $V_{O \text {-acylation }}$ corresponds to the apparent reaction rate for lipase catalyzed $O$-acylation. From Equation 1:

$[$ Intermediate $]=V_{\text {O-acylation }} / k_{\text {acyl migration }}$

By using the nomenclature in Table 1, $V_{O-a c y l a t i o n}$ is given by:

$V_{\text {O-acylation }}=k_{\text {cat,app }} * \mathrm{E}_{0}$

where $\mathrm{E}_{0}$ is the amount of enzyme. The rate constant for $O$ - to $\mathrm{N}$-acyl migration is much less than $1 \mathrm{~min}^{-1}$. By using this value (i.e. setting $k_{\text {acyl migration }}=1 \mathrm{~min}^{-1}$ ) acyl migration is assumed to be much more important than what has been found experimentally. In Table 1 it is shown that $k_{\text {cat,app }}$ is at least $54 \mathrm{~min}^{-1}$ for the $O$-acylation of a secondary hydroxyl. By using $10 \mathrm{mg}$ beads with immobilized enzyme in a $2 \mathrm{~mL}$ reaction volume (corresponding to an enzyme concentration of $7.1 \mu \mathrm{M}$ as determined by active site titration) the following steady state concentration is obtained:

$[$ Intermediate $]=54 \mathrm{~min}^{-1} * 7.1 * 10^{-6} \mathrm{M} /\left(1 \mathrm{~min}^{-1}\right)=0.4 \mathrm{mM}$.

A concentration of $0.4 \mathrm{mM}$ of the $O$-acylated intermediate corresponds to a "minimal" concentration since acyl migration proceeds much more slowly than $60 \mathrm{~h}^{-1}$ as discussed in the paper. The detection limit of the $O$-acylated intermediate in our experimental setup is $2 \mu \mathrm{M}$. The minimal concentration of the presumed $O$-acylated intermediate is thus at least 200 times higher than the detection limit. 
For comparison by using $k_{\text {acyl migration }}=1 \mathrm{~h}^{-1}$ and $k_{\text {cat,app }}=260 \mathrm{~min}^{-1}$ (the value for the lipase catalyzed acylation of a primary hydroxyl group, Table 1) a steady-state concentration of 100 $\mathrm{mM}$ is obtained!

As no $O$-acylated intermediate was observed in any experiment it can be concluded that acyl migration is of minor importance in lipase catalyzed $\mathrm{N}$-acylation of amino alcohols. 
Table S3: Gradient elution for HPLC analysis of products resulting from acylation of 1,2-propanediol

\begin{tabular}{|c|c|c|c|}
\hline $\begin{array}{c}\text { Time } \\
{[\mathrm{min}]}\end{array}$ & $\begin{array}{c}\text { Flow rate } \\
{[\mathrm{ml} / \mathrm{min}]}\end{array}$ & $\% \mathrm{~A}$ & $\% \mathrm{~B}$ \\
\hline 0 & 0,75 & 100 & 0 \\
\hline 30 & 0,75 & 100 & 0 \\
\hline 32 & 0,75 & 0 & 100 \\
\hline 57 & 0,75 & 0 & 100 \\
\hline 59 & 0,75 & 100 & 0 \\
\hline 82 & 0,75 & 100 & 0 \\
\hline
\end{tabular}

Table S4: Gradient elution for HPLC analysis of products resulting from acylation of amino-alcohols

\begin{tabular}{|c|c|c|c|}
\hline $\begin{array}{c}\text { Time } \\
{[\mathrm{min}]}\end{array}$ & $\begin{array}{c}\text { Flow rate } \\
{[\mathrm{ml} / \mathrm{min}]}\end{array}$ & $\% \mathrm{~A}$ & $\% \mathrm{~B}$ \\
\hline 0 & 1 & 100 & 0 \\
\hline 20 & 1 & 100 & 0 \\
\hline 23 & 1 & 0 & 100 \\
\hline 80 & 1 & 0 & 100 \\
\hline 82 & 1 & 100 & 0 \\
\hline 90 & 1 & 100 & 0 \\
\hline
\end{tabular}




\section{Cartesian coordinates of calculated structures}

Conformations of amino alcohols, geometry optimization by employing B3LYP/6$31 G(d, p)$

$(R)$-alaninol, conformations in the same order as in Table 2

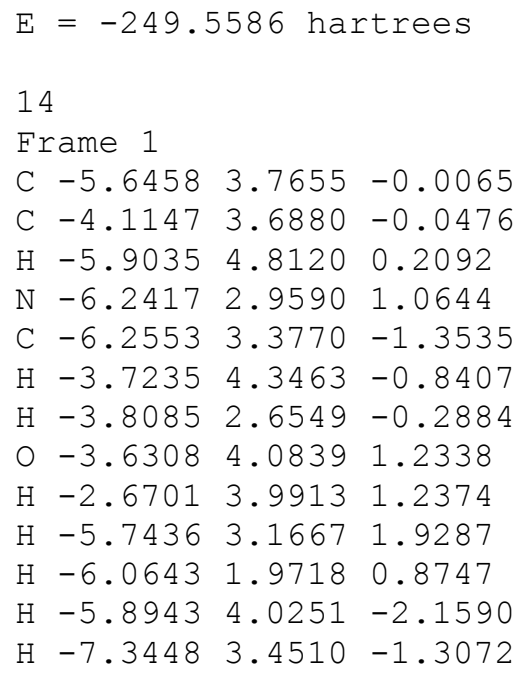




\section{(R)-4-amino-1-pentanol,}

\section{conformations in the same order as in Table 2}

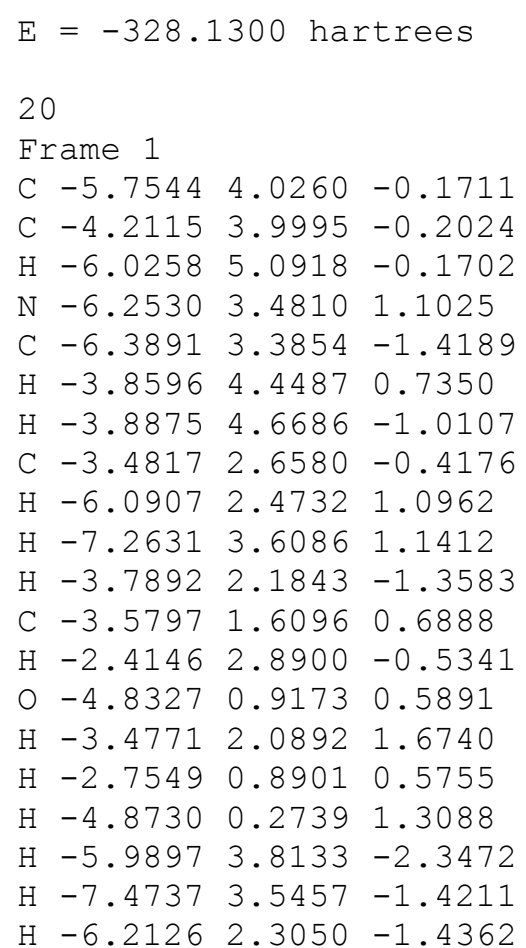

$E=-328.1400$ hartrees

20

Frame 1

C $-5.7378 \quad 4.0409-0.1810$

C $-4.1937 \quad 4.0288-0.1866$

$\mathrm{H}-6.03745 .1018-0.2360$

$\mathrm{N}-6.2493 \quad 3.4264 \quad 1.0667$

C $-6.3614 \quad 3.3135-1.3749$

$\mathrm{H}-3.8464 \quad 4.4638 \quad 0.7634$

$\mathrm{H}-3.8743 \quad 4.7336-0.9654$

C $-3.46132 .6934-0.4251$

$\mathrm{H}-7.2673 \quad 3.4523 \quad 1.0765$

$\mathrm{H}-5.9380 \quad 3.9636 \quad 1.8740$

$\mathrm{H}-3.7527 \quad 2.2685-1.3937$

C $-3.6258 \quad 1.6038 \quad 0.6450$

$\mathrm{H}-2.3895 \quad 2.9250-0.5041$

$\begin{array}{llll}0 & -4.9074 & 1.0098 & 0.6775\end{array}$

$\mathrm{H}-3.34562 .0199 \quad 1.6309$

$\mathrm{H}-2.9134 \quad 0.7979 \quad 0.4308$

$\mathrm{H}-5.5242 \quad 1.72350 .9593$

$\mathrm{H}-5.9554 \quad 3.6930-2.3180$

$\mathrm{H}-7.4473 \quad 3.4644-1.3973$

$\mathrm{H}-6.16422 .2403-1.3104$ 
Cartesian coordinates of calculated structures using the small active site model of a serine hydrolase consisting of 47 atoms

\section{Geometries optimized at the B3LYP/6-31G(d,p) level}

\section{Proton shuttle mechanism for $\mathrm{N}$-acylation of ethanol amine:}

$\underline{\text { Starting complex ("ES-complex") for the proton shuttle mechanism of } N \text {-acylation }}$

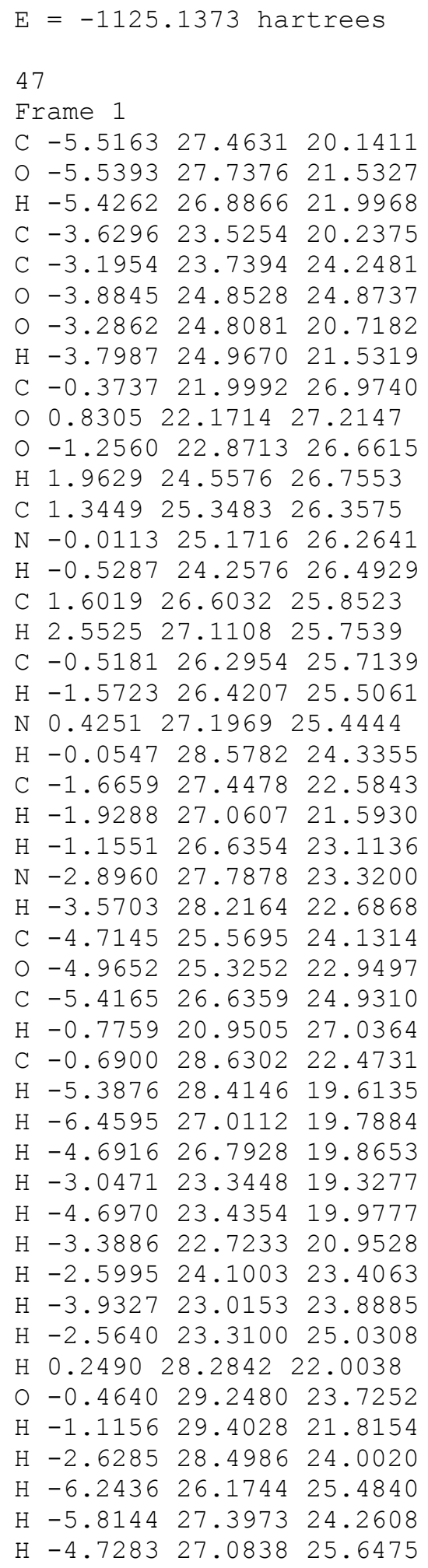




\section{TS for the proton shuttle mechanism of $\mathrm{N}$-acylation}

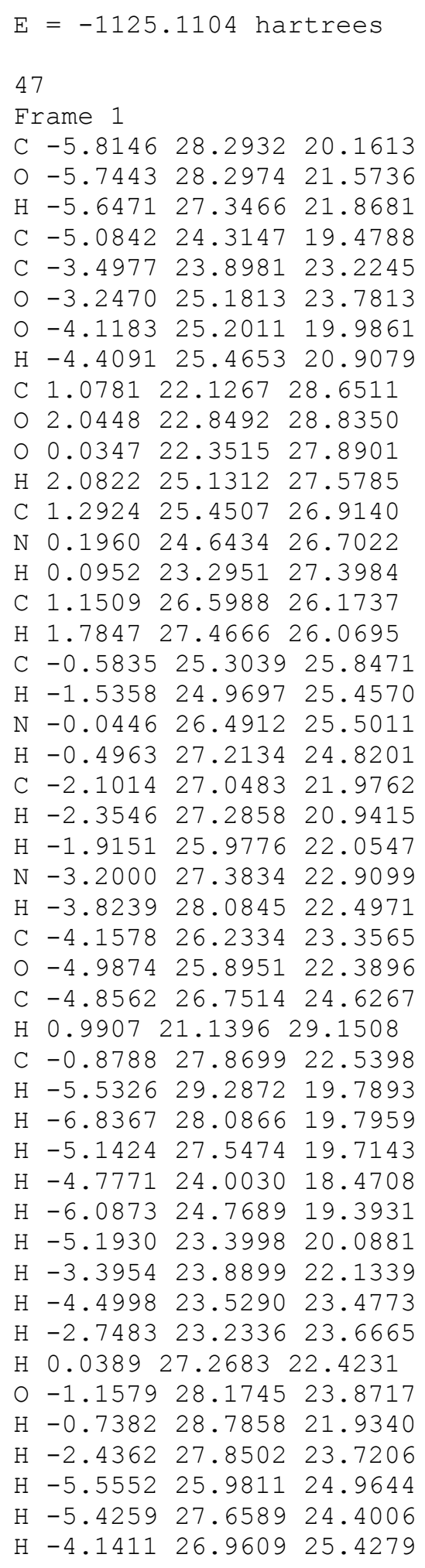




\section{Proton shuttle mechanism for $\boldsymbol{O}$-acylation of ethanol amine:}

$\underline{\text { Starting complex ("ES-complex") for the proton shuttle mechanism of } O \text {-acylation }}$

This structure had one very small imaginary frequency (-9.6) that we neglected since it will have a minimal impact on the energy.

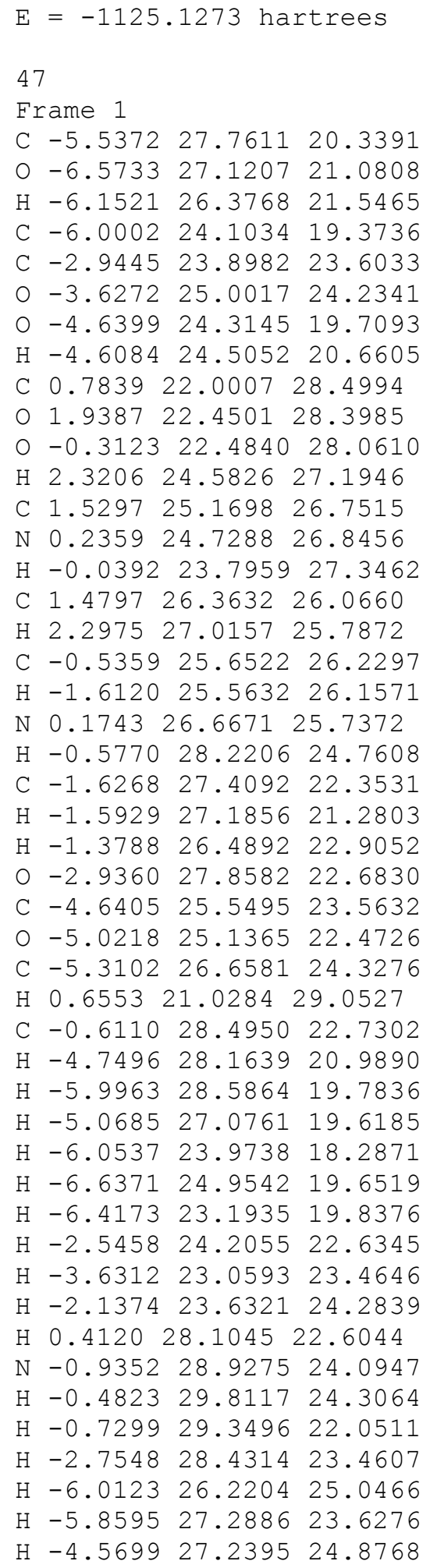




\section{TS for the proton shuttle mechanim of $O$-acylation}

The TS-structure could not be fully relaxed at the B3LYP/6-31G(d,p) level. Therefore an optimization with constraints were performed to obtain a TS-model. The His $\mathrm{N}_{\varepsilon 2}-\mathrm{H}$ bond length was kept fixed at $1.08 \AA$ and the distance between the hydroxyl proton and oxygen of the amino alcohol was set to $1.18 \AA$. These were the distances found in TS at the HF/6$31 \mathrm{G}(\mathrm{d}, \mathrm{p})$ level (the TS-structure could be fully relaxed at the $\mathrm{HF} / 6-31 \mathrm{G}(\mathrm{d}, \mathrm{p})$ level). Our TSmodel at the B3LYP/6-31G(d,p) level had one imaginary frequency of $946.3 \mathrm{i} \mathrm{cm} \mathrm{cm}^{-1}$ corresponding to nucleophilic attack by the oxygen atom of ethanol amine and the transfer of two protons.

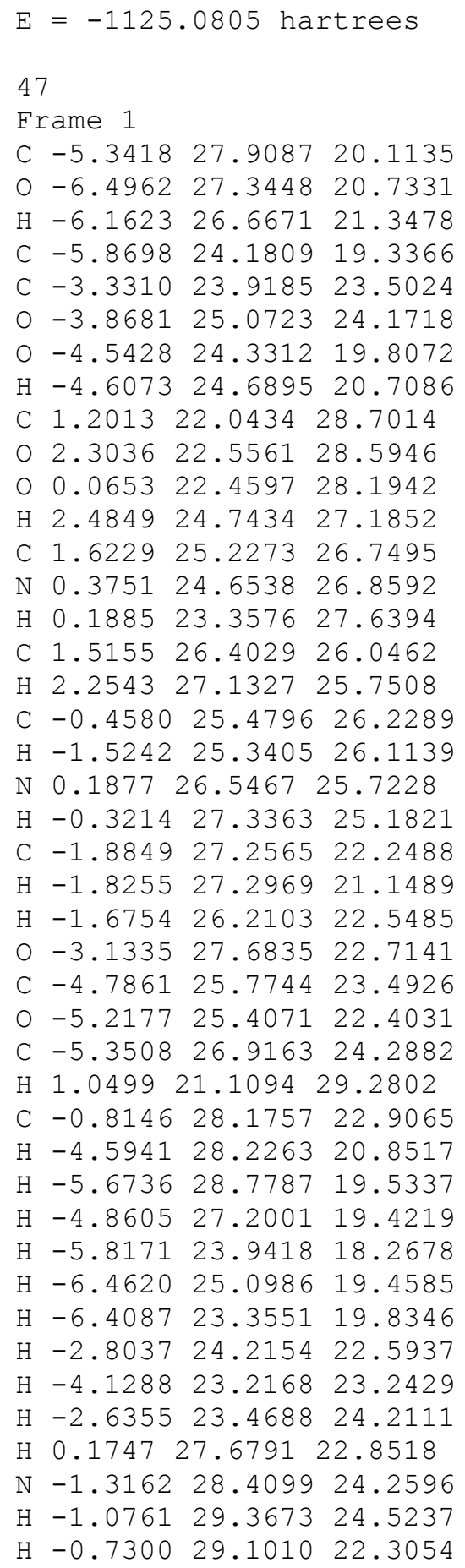


$\mathrm{H}-2.7138 \quad 28.2980 \quad 23.6299$

H $-6.1766 \quad 26.5407 \quad 24.9064$

H $-5.7307 \quad 27.6667 \quad 23.5960$

H $\quad-4.581927 .3448 \quad 24.9291$ 
Cartesian coordinates of calculated structures using the small active site model of a serine hydrolase consisting of 48 atoms

\section{Geometries optimized at the B3LYP/6-31G(d,p) level}

\section{Proton shuttle mechanism for $\mathrm{N}$-acylation of 1,2-diaminoethane}

This computed transition state structure shows that the proton shuttle mechanism is possible for other substrate assisting groups than a hydroxyl.

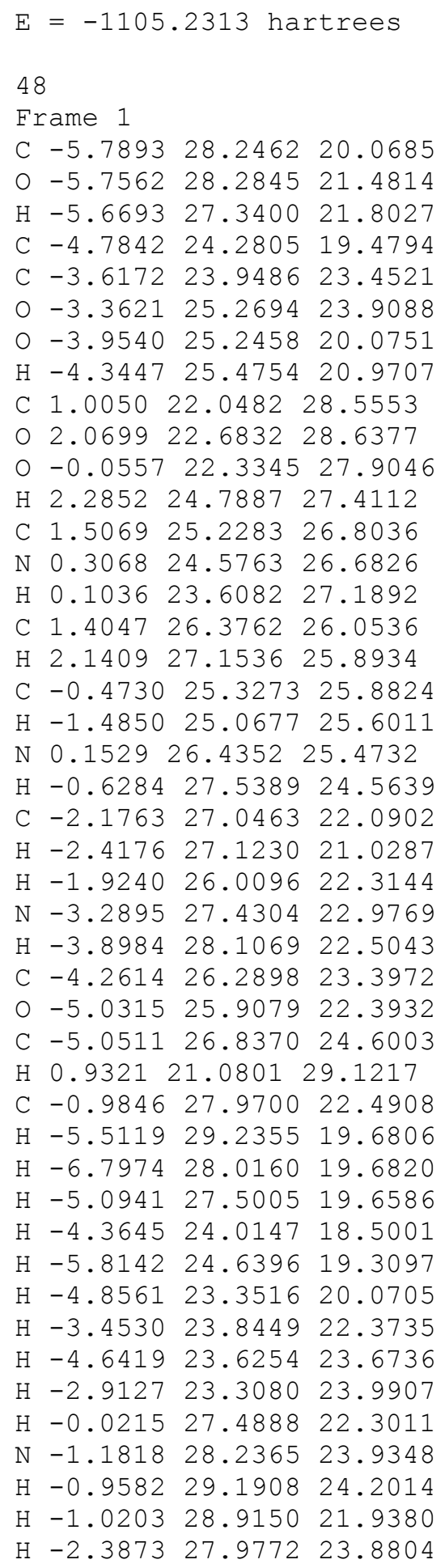


$\mathrm{H}-5.7562 \quad 26.0650 \quad 24.9207$

$\mathrm{H}-5.6236 \quad 27.7227 \quad 24.3042$

$\mathrm{H}-4.3958 \quad 27.0888 \quad 25.4400$ 
Cartesian coordinates of calculated structures for the different mechanisms using the large active site model of Candida antarctica lipase B consisting of 205 atoms

\section{Geometries calculated by employing B3LYP/6-31G(d,p)}

The following atoms were kept fixed for the production of the final B3LYP/6-31G(d,p) geometries and hessian calculations (corresponding to backbone atoms in the enzyme):

Atom 23 (G41), Atom 67 (D187), Atom 103 (V190), Atom 135 (H224), Atom 140 (L278), Atom 157 (A281), Atom 165 (I285)

\section{Proton shuttle mechanism of $N$-acvlation:}

ES-complex for the proton shuttle mechanism of $N$-acylation

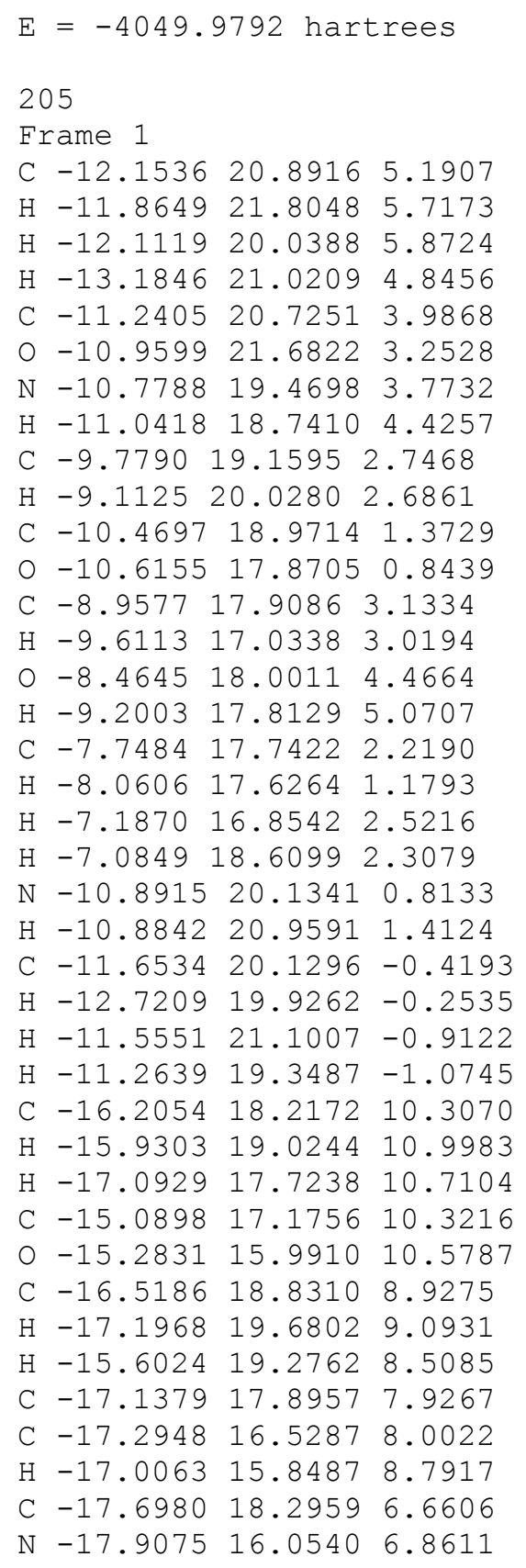




\begin{tabular}{|c|c|c|c|}
\hline $\mathrm{H}$ & -18.1781 & 15.0864 & 6.6957 \\
\hline C & -18.1705 & 17.1126 & 6.0224 \\
\hline $\mathrm{C}$ & -17.8507 & 19.5304 & 6.0041 \\
\hline $\mathrm{H}$ & -17.4917 & 20.4486 & 6.4632 \\
\hline C & -18.7758 & 17.1429 & 4.7600 \\
\hline $\mathrm{H}$ & -19.1254 & 16.2297 & 4.2872 \\
\hline C & -18.4580 & 19.5628 & 4.7542 \\
\hline $\mathrm{H}$ & -18.5782 & 20.5118 & 4.2382 \\
\hline C & -18.9138 & 18.3791 & 4.1372 \\
\hline $\mathrm{H}$ & -19.3820 & 18.4344 & 3.1580 \\
\hline $\mathrm{N}$ & -13.8353 & 17.6541 & 10.0458 \\
\hline $\mathrm{H}$ & -13.6963 & 18.6389 & 9.8760 \\
\hline C & -12.6618 & 16.7959 & 10.1594 \\
\hline $\mathrm{H}$ & -12.8930 & 16.0313 & 10.9052 \\
\hline C & -11.4743 & 17.6045 & 10.7268 \\
\hline 0 & -10.9684 & 17.3314 & 11.8069 \\
\hline C & -12.3404 & 16.0350 & 8.8659 \\
\hline $\mathrm{H}$ & -13.2381 & 15.5321 & 8.4976 \\
\hline $\mathrm{H}$ & -11.5605 & 15.2967 & 9.0732 \\
\hline 0 & -11.8936 & 16.9741 & 7.8650 \\
\hline $\mathrm{N}$ & -11.0896 & 18.6778 & 9.9679 \\
\hline $\mathrm{H}$ & -11.3243 & 18.6412 & 8.9826 \\
\hline C & -9.9493 & 19.4897 & 10.3681 \\
\hline $\mathrm{H}$ & -9.9732 & 20.4351 & 9.8205 \\
\hline $\mathrm{H}$ & -10.0126 & 19.6879 & 11.4394 \\
\hline $\mathrm{H}$ & -8.9923 & 18.9894 & 10.1720 \\
\hline C & -17.0980 & 7.2870 & 8.7218 \\
\hline C & -17.6769 & 5.9805 & 8.1718 \\
\hline $\mathrm{H}$ & -18.2164 & 5.4214 & 8.9444 \\
\hline $\mathrm{H}$ & -16.8703 & 5.3517 & 7.7838 \\
\hline $\mathrm{H}$ & -18.3748 & 6.1698 & 7.3480 \\
\hline $\mathrm{H}$ & -17.8855 & 7.9637 & 9.0684 \\
\hline $\mathrm{H}$ & -16.4693 & 7.0653 & 9.5964 \\
\hline C & -16.2035 & 8.0502 & 7.7244 \\
\hline O & -15.4534 & 7.3667 & 6.9714 \\
\hline O & -16.2651 & 9.3141 & 7.7721 \\
\hline $\mathrm{N}$ & -14.1490 & 6.0300 & 4.7932 \\
\hline C & -14.3737 & 4.7846 & 4.2959 \\
\hline O & -13.6841 & 4.2472 & 3.4282 \\
\hline C & -15.5591 & 4.0581 & 4.9236 \\
\hline $\mathrm{H}$ & -16.0436 & 53.4502 & 4.1561 \\
\hline $\mathrm{H}$ & -16.2851 & 4.7376 & 5.3782 \\
\hline $\mathrm{H}$ & -15.1890 & 3.3814 & 5.7025 \\
\hline $\mathrm{H}$ & -14.7804 & 6.4066 & 5.4999 \\
\hline C & -12.9974 & 6.8358 & 4.3994 \\
\hline $\mathrm{H}$ & -12.4521 & 6.2502 & 3.6575 \\
\hline C & -12.0003 & 7.0233 & 5.5650 \\
\hline O & -10.7898 & 6.8873 & 5.3821 \\
\hline C & -13.4289 & 8.2017 & 3.7925 \\
\hline $\mathrm{H}$ & -13.9598 & 8.7455 & 4.5855 \\
\hline C & -14.4358 & 8.0329 & 2.6311 \\
\hline $\mathrm{H}$ & -15.3313 & 7.5316 & 3.0166 \\
\hline $\mathrm{H}$ & -14.7553 & 9.0383 & 2.3255 \\
\hline C & -12.2140 & 9.0464 & 3.3759 \\
\hline $\mathrm{H}$ & -11.6190 & 8.5460 & 2.6044 \\
\hline $\mathrm{H}$ & -11.5422 & 9.2355 & 4.2172 \\
\hline $\mathrm{H}$ & -12.5452 & 10.0126 & 52.9802 \\
\hline $\mathrm{C}$ & -13.9252 & 7.2622 & 1.4050 \\
\hline $\mathrm{H}$ & -13.0449 & 7.7404 & 0.9621 \\
\hline $\mathrm{H}$ & -14.6994 & 7.2249 & 0.6293 \\
\hline $\mathrm{H}$ & -13.663 & 6.2303 & 1.6588 \\
\hline
\end{tabular}



$\mathrm{N}-12.5422 \quad 7.3627 \quad 6.7685$
$\mathrm{H}-13.5572 \quad 7.43796 .8673$
C -11.72657 .42957 .9713$
$\mathrm{H}-12.2203 \quad 6.8445 \quad 8.7600$
H $-10.7766 \quad 6.9453 \quad 7.7311$
C -11.45398 .85518 .5030$
$\mathrm{H}-10.7591 \quad 8.7227 \quad 9.3479$
C $-10.7546 \quad 9.7287 \quad 7.4530$
$\mathrm{H}-11.4263 \quad 9.9331 \quad 6.6118$
$\mathrm{H}-9.8673 \quad 9.2335 \quad 7.0467$
$\mathrm{H}-10.450210 .6905 \quad 7.8832$
C -12.72549 .52489 .0428$
$\mathrm{H}-13.49959 .6107 \quad 8.2729$
H $-12.5119 \quad 10.53329 .4170$
$\mathrm{H}-13.1584 \quad 8.9508 \quad 9.8707$
C $-18.8269 \quad 10.9094 \quad 6.1751$
$\mathrm{H}-19.6699 \quad 10.2215 \quad 6.3224$
$\mathrm{H}-18.226210 .8965 \quad 7.0869$
C $-19.3565 \quad 12.3161 \quad 5.9454$
O $-18.8173 \quad 13.3246 \quad 6.3994$
C $-17.9640 \quad 10.3970 \quad 4.9880$
$\mathrm{H}-17.7890 \quad 9.3276 \quad 5.1500$
$\mathrm{H}-18.5244 \quad 10.4877 \quad 4.0495$
C $-16.6491 \quad 11.09514 .8379$
$\mathrm{N}-15.6222 \quad 10.8924 \quad 5.7330$
$\mathrm{H}-15.6957 \quad 10.2343 \quad 6.5606$
C $-16.163011 .9926 \quad 3.9136$
$\mathrm{H}-16.6654 \quad 12.4002 \quad 3.0467$
C $-14.5821 \quad 11.6530 \quad 5.3259$
$\mathrm{H}-13.635511 .6753 \quad 5.8476$
$\mathrm{N}-14.8656 \quad 12.3393 \quad 4.2245$
$\mathrm{H}-14.7717 \quad 15.6505 \quad 5.6666$
$\mathrm{N}-20.4856 \quad 12.3825 \quad 5.1775$
$\mathrm{H}-20.842911 .52424 .7861$
C $-21.0980 \quad 13.6360 \quad 4.7740$
$\mathrm{H}-20.6868 \quad 14.0167 \quad 3.8286$
$\mathrm{H}-22.1759 \quad 13.4992 \quad 4.6571$
H $-20.9129 \quad 14.3780 \quad 5.5518$
C $-20.0788 \quad 12.8176-0.9771$
C $-19.597214 .2326-0.6389$
$\mathrm{H}-20.4443 \quad 14.9122-0.4916$
$\mathrm{H}-18.9793 \quad 14.6444-1.4454$
$\mathrm{H}-18.9979 \quad 14.2557 \quad 0.2766$
H $-20.6855 \quad 12.4273-0.1463$
$\mathrm{H}-20.7531 \quad 12.8715-1.8434$
C $-18.959311 .8042-1.2885$
$\mathrm{H}-18.3512 \quad 12.2225-2.1057$
C $-18.0317 \quad 11.5663-0.0871$
$\mathrm{H}-18.5967 \quad 11.1752 \quad 0.7691$
$\mathrm{H}-17.5289 \quad 12.4836 \quad 0.2340$
$\mathrm{H}-17.2530 \quad 10.8350-0.3276$
C $-19.5562 \quad 10.4768-1.7803$
$\mathrm{H}-18.7705 \quad 9.7598-2.0411$
$\mathrm{H}-20.1866 \quad 10.6238-2.6650$
$\mathrm{H}-20.1781 \quad 10.0162-1.0020$
C $-16.385517 .3141-0.2890$
C $-15.2107 \quad 17.5496-1.2397$
$\mathrm{H}-15.2270 \quad 18.5650-1.6530$
$\mathrm{H}-15.2310 \quad 16.8513-2.0842$
$\mathrm{H}-14.2505 \quad 17.4163-0.7283$
H -16.364916 .30010 .1238$ 


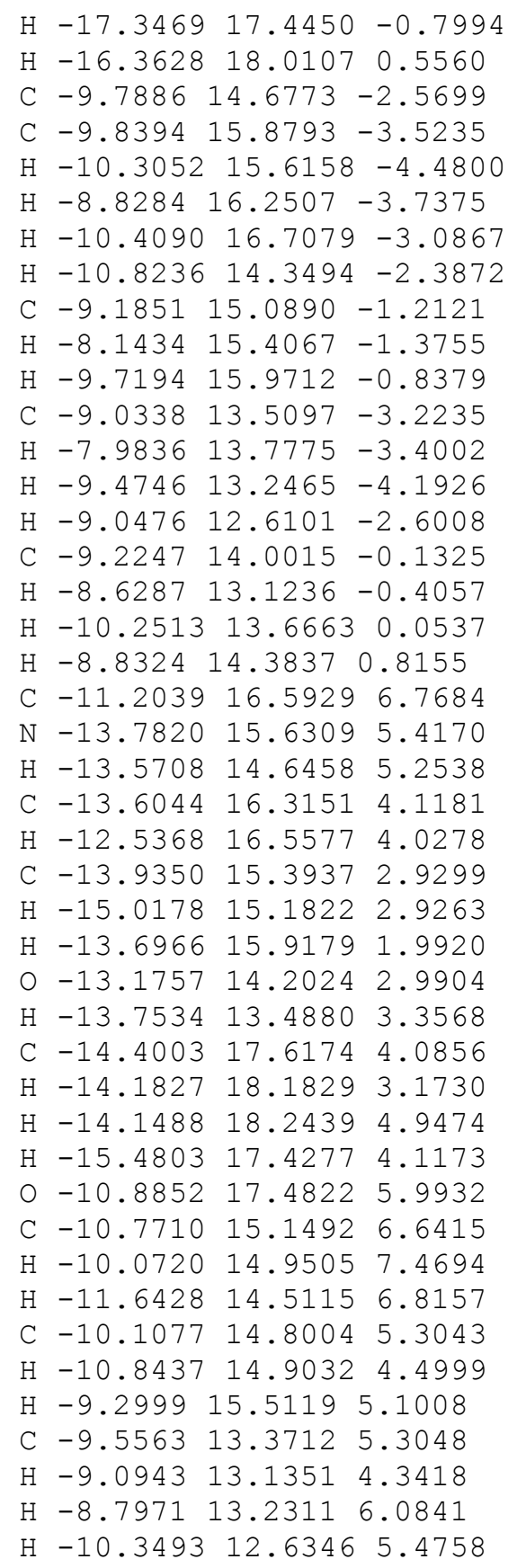

\section{$\underline{\text { TS for the proton shuttle mechanism of } N \text {-acylation }}$}

One imaginary frequency $\left(1028.1 \mathrm{i} \mathrm{cm}^{-1}\right)$ corresponded to nucleophilic attack and the transfer of two protons.

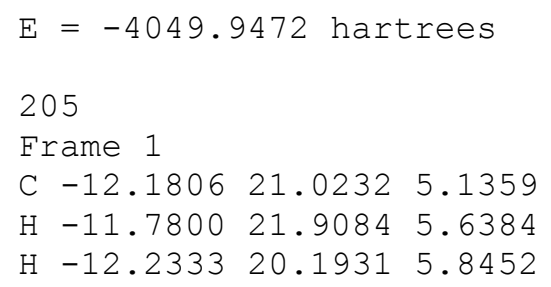




$$
\begin{aligned}
& \text { H }-13.1892 \quad 21.2737 \quad 4.7914 \\
& \text { C }-11.3020 \quad 20.7133 \quad 3.9340 \\
& \begin{array}{l}
0-11.0242 \quad 21.59293 .1017
\end{array} \\
& \mathrm{~N}-10.8678 \quad 19.4389 \quad 3.8454 \\
& \mathrm{H}-11.1142 \quad 18.7625 \quad 4.5794 \\
& \text { C }-9.8680 \quad 19.03652 .8552 \\
& \mathrm{H}-9.1958 \quad 19.8922 \quad 2.7160 \\
& \text { C }-10.5541 \quad 18.7362 \quad 1.5004 \\
& \text { O }-10.780517 .59361 .0962 \\
& \text { C }-9.0528 \quad 17.8126 \quad 3.3432 \\
& \mathrm{H}-9.686616 .9279 \quad 3.2054
\end{aligned}
$$

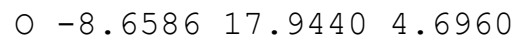

$$
\begin{aligned}
& \mathrm{H}-9.4446 \quad 17.7138 \quad 5.2448 \\
& \text { C }-7.7902 \quad 17.6423 \quad 2.5021 \\
& \mathrm{H}-8.0307 \quad 17.5314 \quad 1.4410 \\
& \mathrm{H}-7.2484 \quad 16.7515 \quad 2.8324 \\
& \mathrm{H}-7.1295 \quad 18.5073 \quad 2.6322 \\
& \mathrm{~N}-10.8755 \quad 19.8513 \quad 0.7950 \\
& \mathrm{H}-10.8608 \quad 20.7276 \quad 1.3186 \\
& \text { C }-11.6121 \quad 19.7519-0.4490 \\
& \mathrm{H}-12.6853 \quad 19.5739-0.2931 \\
& \mathrm{H}-11.491720 .6790-1.0159 \\
& \text { H }-11.219018 .9176-1.0339 \\
& \text { C }-16.2605 \quad 18.1657 \quad 10.3457 \\
& \mathrm{H}-15.975918 .962511 .0449 \\
& \mathrm{H}-17.1440 \quad 17.6695 \quad 10.7549 \\
& \text { C }-15.1452 \quad 17.1179 \quad 10.3564 \\
& \begin{array}{llll}
0 & -15.3304 & 15.9785 & 10.7798
\end{array} \\
& \text { C }-16.592618 .7999 \quad 8.9831 \\
& \mathrm{H}-17.2924 \quad 19.6279 \quad 9.1654 \\
& \text { H }-15.694319 .28118 .5653 \\
& \text { C }-17.1908 \quad 17.8710 \quad 7.9634 \\
& \text { C }-17.302616 .4990 \quad 8.0048 \\
& \text { H }-16.9885 \quad 15.8091 \quad 8.7761 \\
& \text { C }-17.7736 \quad 18.2846 \quad 6.7123 \\
& \mathrm{~N}-17.910916 .03326 .8550 \\
& \mathrm{H}-18.1192 \quad 15.0568 \quad 6.6573 \\
& \text { C }-18.2111 \quad 17.1046 \quad 6.0435 \\
& \text { C }-17.9767 \quad 19.53296 .0972 \\
& \mathrm{H}-17.6518 \quad 20.4479 \quad 6.5865 \\
& \text { C }-18.8254 \quad 17.1556 \quad 4.7857 \\
& \mathrm{H}-19.1371 \quad 16.2485 \quad 4.2773 \\
& \text { C }-18.5976 \quad 19.5842 \quad 4.8549 \\
& \mathrm{H}-18.7597 \quad 20.5446 \quad 4.3726 \\
& \text { C }-19.0150 \quad 18.4051 \quad 4.2043 \\
& \mathrm{H}-19.4898 \quad 18.4730 \quad 3.2291 \\
& \mathrm{~N}-13.9279 \quad 17.5466 \quad 9.9135 \\
& \mathrm{H}-13.8380 \quad 18.4568 \quad 9.4875 \\
& \text { C }-12.7372 \quad 16.70299 .9760 \\
& \mathrm{H}-12.9197 \quad 15.9767 \quad 10.7710 \\
& \text { C }-11.5400 \quad 17.5600 \quad 10.4524 \\
& \begin{array}{llll}
0 & -11.2134 & 17.5891 & 11.6364
\end{array} \\
& \text { C }-12.4922 \quad 15.9173 \quad 8.6788 \\
& \mathrm{H}-13.3694 \quad 15.2766 \quad 8.4984 \\
& \mathrm{H}-11.6268 \quad 15.2636 \quad 8.8424 \\
& \begin{array}{l}
\mathrm{O}-12.2783 \quad 16.8316 \quad 7.6121 \\
\hline
\end{array} \\
& \mathrm{N}-10.9384 \quad 18.30729 .4886 \\
& \mathrm{H}-11.1667 \quad 18.0885 \quad 8.5187 \\
& \text { C }-9.784619 .13039 .8030 \\
& \mathrm{H}-9.6186 \quad 19.83918 .9886 \\
& \text { H }-9.966619 .673910 .7332
\end{aligned}
$$




\begin{tabular}{|c|c|c|c|}
\hline & -8.8743 & 18.5318 & 9.9386 \\
\hline & -16.7937 & 7.2324 & 8.5672 \\
\hline & -17.6512 & 6.2055 & 7.8208 \\
\hline & -18.0744 & 5.4656 & 8.5090 \\
\hline $\mathrm{H}$ & -17.0524 & 5.6788 & 7.0747 \\
\hline & -18.4854 & 6.6908 & 7.3007 \\
\hline & -17.3805 & 7.7759 & 9.3128 \\
\hline $\mathrm{H}$ & -15.9853 & 6.7127 & 9.0987 \\
\hline 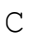 & -16.1439 & 8.2415 & 7.6152 \\
\hline 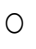 & -15.5074 & 7.8033 & 6.6189 \\
\hline 0 & -16.2970 & 9.4748 & \\
\hline & -14.1441 & 6.0235 & 4.7906 \\
\hline$\checkmark$ & -14.3816 & 4.7860 & 4.2750 \\
\hline 0 & -13.6804 & 4.2461 & \\
\hline C & -15.6055 & 4.0839 & 4.8580 \\
\hline $\mathrm{H}$ & -15.8063 & 3.1888 & 4.2683 \\
\hline $\mathrm{H}$ & -16.4859 & 4.7349 & \\
\hline $\mathrm{H}$ & -15.4165 & 3.7906 & 5.8968 \\
\hline $\mathrm{H}$ & -14.7989 & 6.4291 & 5.4583 \\
\hline C & -12.9918 & 6.8287 & \\
\hline $\mathrm{H}$ & -12.4415 & 6.2342 & 3.6633 \\
\hline C & -12.0010 & 7.0257 & 5.5650 \\
\hline 0 & -10.7977 & & \\
\hline C & -13.4182 & 8.1874 & 3.7667 \\
\hline $\mathrm{H}$ & -13.9436 & 8.7464 & 4.5526 \\
\hline C & -14.4304 & 8.00 & \\
\hline $\mathrm{H}$ & -15.3281 & 7.5186 & 3.0 \\
\hline $\mathrm{H}$ & -14.7455 & 9.0107 & 2.2922 \\
\hline C & -12.1925 & 72 & \\
\hline $\mathrm{H}$ & -11.5978 & 8.4754 & 2.5819 \\
\hline $\mathrm{H}$ & -11.5258 & 9.2187 & 4.1718 \\
\hline $\mathrm{H}$ & -12.5072 & 9.9637 & \\
\hline C & -13.9317 & 7.2186 & 1.3919 \\
\hline $\mathrm{H}$ & -13.0547 & 7.6890 & 0.9348 \\
\hline $\mathrm{H}$ & -14.7126 & 7.1715 & 0.6 \\
\hline $\mathrm{H}$ & -13.6690 & 6.1902 & 1.6581 \\
\hline N & -12.5444 & 7.4500 & 6.7431 \\
\hline $\mathrm{H}$ & -13.5507 & 7.5986 & 6.7977 \\
\hline $\mathrm{C}$ & -11.7469 & 7.5624 & 7.9574 \\
\hline $\mathrm{H}$ & -12.2507 & 7.0095 & 8.7629 \\
\hline $\mathrm{H}$ & -10.7978 & 7.0627 & 7.7470 \\
\hline C & -11.4744 & 9.0063 & 8.4330 \\
\hline $\mathrm{H}$ & -10.7889 & 8.9065 & 9.2890 \\
\hline C & -10.7658 & 9.8364 & 7.3549 \\
\hline $\mathrm{H}$ & -11.4336 & 10.0185 & 56.5054 \\
\hline $\mathrm{H}$ & -9.8818 & 9.32036 & 5.9675 \\
\hline $\mathrm{H}$ & -10.4522 & 10.8089 & 7.7509 \\
\hline $\mathrm{C}$ & -12.7493 & 9.6980 & 8.9340 \\
\hline $\mathrm{H}$ & -13.5061 & 9.7670 & 8.1450 \\
\hline $\mathrm{H}$ & -12.5365 & 10.7145 & 59.2846 \\
\hline $\mathrm{H}$ & -13.2035 & 9.1502 & 9.7680 \\
\hline C & -18.8361 & 10.8130 & 6.0346 \\
\hline $\mathrm{H}$ & -19.7224 & 10.1674 & 6 \\
\hline $\mathrm{H}$ & -18.3466 & 10.6693 & 37.0012 \\
\hline C & -19.2336 & 12.2755 & 5.9075 \\
\hline 0 & -18.5542 & 13.1856 & 56.3828 \\
\hline C & -17.8628 & 10.3795 & 54.9037 \\
\hline $\mathrm{H}$ & -17.6570 & 9.3099 & 5.0244 \\
\hline $\mathrm{H}$ & -18.3400 & 10.5089 & 3.9258 \\
\hline C & -16.5703 & 11.1318 & 34.9108 \\
\hline $\mathrm{N}$ & -15.6761 & 11.0177 & 75.9533 \\
\hline
\end{tabular}



$\mathrm{H}-15.8398 \quad 10.3464 \quad 6.8220$
C $-16.0260 \quad 12.0267 \quad 4.0234$
$\mathrm{H}-16.4073 \quad 12.39153 .0821$
C -14.638711 .81635 .6958$
$\mathrm{H}-13.7777 \quad 11.9324 \quad 6.3361$
$\mathrm{N}-14.8154 \quad 12.4436 \quad 4.5304$
$\mathrm{H}-13.7602 \quad 16.0387 \quad 6.1658$
$\mathrm{N}-20.3720 \quad 12.51015 .1940$
H $-20.8598 \quad 11.7221 \quad 4.7966$
C $-20.8406 \quad 13.84824 .8831$
$\mathrm{H}-20.4242 \quad 14.2243 \quad 3.9400$
$\mathrm{H}-21.9313 \quad 13.8503 \quad 4.8077$
H $-20.5400 \quad 14.5223 \quad 5.6861$
C $-20.0491 \quad 12.8504-0.9507$
C $-19.535914 .2562-0.6199$
$\mathrm{H}-20.3685 \quad 14.9534-0.4737$
H $-18.912514 .6518-1.4300$
$\mathrm{H}-18.9353 \quad 14.2716 \quad 0.2951$
$\mathrm{H}-20.6658 \quad 12.4768-0.1195$
H $-20.7208 \quad 12.9144-1.8180$
C $-18.950911 .8120-1.2555$
H $-18.3271 \quad 12.2184-2.0663$
C $-18.038911 .5535-0.0460$
$\mathrm{H}-18.6207 \quad 11.1690 \quad 0.8023$
H $-17.5256 \quad 12.4628 \quad 0.2822$
$\mathrm{H}-17.2702 \quad 10.8102-0.2823$
C $-19.5724 \quad 10.4985-1.7533$
$\mathrm{H}-18.8006 \quad 9.7660-2.0133$
$\mathrm{H}-20.1946 \quad 10.6619-2.6406$
$\mathrm{H}-20.2082 \quad 10.0488-0.9800$
C $-16.3572 \quad 17.3260-0.2581$
C $-15.176517 .5905-1.1957$
$\mathrm{H}-15.116218 .6501-1.4687$
H $-15.2670 \quad 17.0164-2.1246$
$\mathrm{H}-14.2256 \quad 17.3155-0.7275$
$\mathrm{H}-16.4229 \quad 16.2660 \quad 0.0107$
$\mathrm{H}-17.3097 \quad 17.6080 \quad-0.7214$
H $-16.263917 .8942 \quad 0.6736$
C $-9.7614 \quad 14.6815-2.6096$
C $-9.7624 \quad 15.8626-3.5917$
$\mathrm{H}-10.2097 \quad 15.5859-4.5534$
$\mathrm{H}-8.7393 \quad 16.2071-3.7884$
$\mathrm{H}-10.3251 \quad 16.7127-3.1905$
H $-10.8070 \quad 14.3739-2.4522$
C $-9.1951 \quad 15.1148-1.2427$
$\mathrm{H}-8.1554 \quad 15.4481-1.3838$
$\mathrm{H}-9.7524 \quad 15.9906-0.8868$
C $-9.008013 .4875-3.2149$
$\mathrm{H}-7.9490 \quad 13.7334-3.3689$
$\mathrm{H}-9.426913 .2089-4.1894$
$\mathrm{H}-9.053812 .6033-2.5720$
C $-9.242214 .0390-0.1520$
$\mathrm{H}-8.594913 .1855-0.3813$
$\mathrm{H}-10.2615 \quad 13.6591-0.0157$
$\mathrm{H}-8.9203 \quad 14.4522 \quad 0.8087$
C $-11.6867 \quad 16.40596 .2940$
$\mathrm{N}-12.9813 \quad 15.9452 \quad 5.5155$
$\mathrm{H}-12.9667 \quad 14.8002 \quad 4.9216$
C $-13.3103 \quad 16.60704 .2306$
$\mathrm{H}-12.3656 \quad 16.9797 \quad 3.8320$
C $-13.8066 \quad 15.4244 \quad 3.3279$ 

H $-14.9099 \quad 15.3700 \quad 3.3557$
H $-13.4970 \quad 15.5896 \quad 2.2893$
$\begin{array}{llll}0 & -13.2209 & 14.2498 & 3.8588\end{array}$
$\mathrm{H}-14.0967 \quad 13.2500 \quad 4.1312$
C $-14.3175 \quad 17.7427 \quad 4.3431$
$\mathrm{H}-14.5634 \quad 18.1306 \quad 3.3476$
$\mathrm{H}-13.9166 \quad 18.5667 \quad 4.9377$
H $-15.2528 \quad 17.4062 \quad 4.8065$
$0-11.1082 \quad 17.4305 \quad 5.7583$
C $-10.7984 \quad 15.1537 \quad 6.4902$
$\mathrm{H}-10.0682 \quad 15.3911 \quad 7.2750$
H $-11.4006 \quad 14.31196 .8581$
C $-10.0423 \quad 14.7203 \quad 5.2275$
$\mathrm{H} \quad-10.7437 \quad 14.5918 \quad 4.3953$
$\mathrm{H}-9.3475 \quad 15.5169 \quad 4.9489$
C $-9.2657 \quad 13.4154 \quad 5.4371$
$\mathrm{H} \quad-8.7039 \quad 13.1421 \quad 4.5376$
$\mathrm{H}-8.5493 \quad 13.5056 \quad 6.2626$
H $\quad-9.9367 \quad 12.5802 \quad 5.6719$ 


\section{$\underline{\text { Traditional mechanism: }}$}

Note that this would the pathway for a (monosubstituted) amine whereas short amino alcohols have been shown to exist exclusively as ring structures with an intramolecular hydrogen bond. We modeled a hydrogen bond to the backbone of T40 donated by the open chain amino alcohol hydroxyl. This hydrogen bond lowers the energy for all structures of the hypothetical traditional reaction mechanism and since it is fully developed in the ES-complex, it does not contribute to catalysis $\left(k_{\text {cat,app }}\right)$.

\section{ES-complex for the traditional mechanism of $N$-acylation}

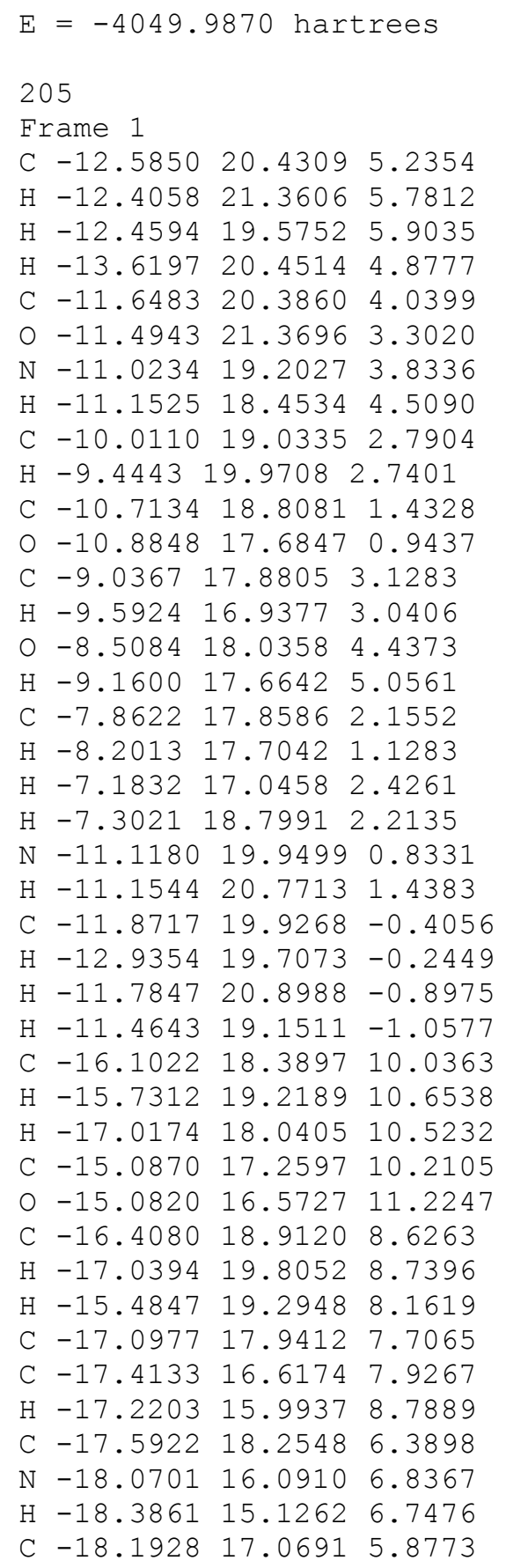




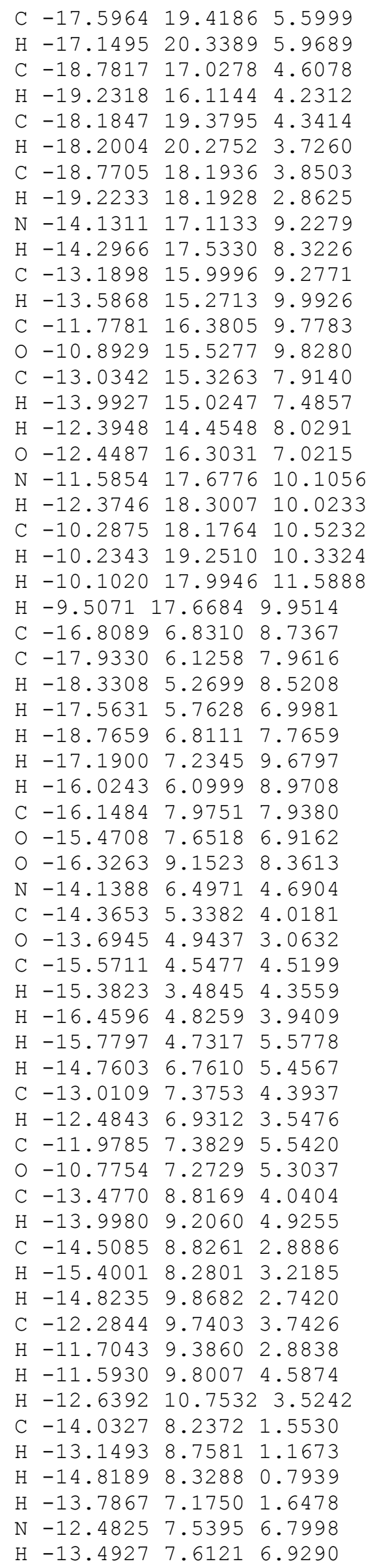




\begin{tabular}{|c|c|c|}
\hline C & -11.6264 & $7.4348 \quad 7.9707$ \\
\hline $\mathrm{H}$ & -12.0511 & 6.68498 .6547 \\
\hline $\mathrm{H}$ & -10.6645 & 7.05967 .6136 \\
\hline $\mathrm{C}$ & -11.4132 & $8.7520 \quad 8.7496$ \\
\hline $\mathrm{H}$ & -10.6841 & $8.5088 \quad 9.5388$ \\
\hline $\mathrm{C}$ & -10.8047 & $9.8474 \quad 7.8639$ \\
\hline $\mathrm{H}$ & -11.5069 & 10.13927 .0756 \\
\hline $\mathrm{H}$ & -9.8867 & $9.5046 \quad 7.3755$ \\
\hline $\mathrm{H}$ & -10.5688 & 10.74098 .4538 \\
\hline C & -12.6999 & 9.23219 .4376 \\
\hline $\mathrm{H}$ & -13.4997 & 9.42798 .7157 \\
\hline $\mathrm{H}$ & -12.5226 & $10.1561 \quad 10.0004$ \\
\hline $\mathrm{H}$ & -13.0794 & $8.4830 \quad 10.1427$ \\
\hline $\mathrm{C}$ & -18.8005 & $10.9655 \quad 6.3638$ \\
\hline $\mathrm{H}$ & -19.5669 & $10.1831 \quad 6.2929$ \\
\hline $\mathrm{H}$ & -18.4348 & 10.98017 .3925 \\
\hline $\mathrm{C}$ & -19.4245 & $12.3158 \quad 6.0474$ \\
\hline 0 & -19.0901 & $13.3647 \quad 6.6001$ \\
\hline C & -17.6266 & 10.61025 .4054 \\
\hline $\mathrm{H}$ & -17.3912 & $9.5498 \quad 5.5478$ \\
\hline $\mathrm{H}$ & -17.9502 & $10.7298 \quad 4.3647$ \\
\hline C & -16.3849 & $11.4127 \quad 5.6307$ \\
\hline $\mathrm{N}$ & -15.5487 & $11.1474 \quad 6.6917$ \\
\hline $\mathrm{H}$ & -15.7136 & $10.3627 \quad 7.3790$ \\
\hline C & -15.8035 & $12.4664 \quad 4.9587$ \\
\hline $\mathrm{H}$ & -16.1594 & $12.9636 \quad 4.0657$ \\
\hline C & -14.5203 & $12.0262 \quad 6.6139$ \\
\hline $\mathrm{H}$ & -13.7044 & 12.02137 .3240 \\
\hline $\mathrm{N}$ & -14.6328 & $12.8493 \quad 5.5779$ \\
\hline $\mathrm{H}$ & -13.3525 & $14.2942 \quad 4.3510$ \\
\hline $\mathrm{N}$ & -20.3904 & 12.28595 .0805 \\
\hline $\mathrm{H}$ & -20.5777 & 11.40554 .6253 \\
\hline C & -21.0556 & $13.4770 \quad 4.5839$ \\
\hline $\mathrm{H}$ & -20.5413 & 13.91213 .7170 \\
\hline $\mathrm{H}$ & -22.0837 & 13.23624 .2976 \\
\hline $\mathrm{H}$ & -21.0717 & 14.22065 .3830 \\
\hline $\mathrm{C}$ & -19.8343 & $12.7156-0.7505$ \\
\hline $\mathrm{C}$ & -19.6143 & $14.2326-0.7225$ \\
\hline $\mathrm{H}$ & -20.5198 & $14.7663-1.0313$ \\
\hline $\mathrm{H}$ & -18.8061 & $14.5278-1.4026$ \\
\hline $\mathrm{H}$ & -19.3499 & $14.5898 \quad 0.2777$ \\
\hline $\mathrm{H}$ & -20.6460 & $12.4490-0.0565$ \\
\hline $\mathrm{H}$ & -20.1883 & $12.4279-1.7503$ \\
\hline C & -18.5933 & $11.8658-0.4104$ \\
\hline $\mathrm{H}$ & -17.7907 & $12.1588-1.1048$ \\
\hline $\mathrm{C}$ & -18.0854 & 12.10921 .0192 \\
\hline $\mathrm{H}$ & -18.8662 & 11.87221 .7547 \\
\hline $\mathrm{H}$ & -17.7821 & $13.1485 \quad 1.1782$ \\
\hline $\mathrm{H}$ & -17.2184 & 11.47821 .2415 \\
\hline $\mathrm{C}$ & -18.8834 & $10.3739-0.6339$ \\
\hline $\mathrm{H}$ & -17.9935 & $9.7633-0.4485$ \\
\hline $\mathrm{H}$ & -19.2176 & $10.1800-1.6597$ \\
\hline $\mathrm{H}$ & -19.6723 & $10.0228 \quad 0.0439$ \\
\hline C & -16.5835 & $17.7317-0.7463$ \\
\hline $\mathrm{C}$ & -15.3616 & $17.4309-1.6192$ \\
\hline $\mathrm{H}$ & -14.9069 & $18.3526-1.9976$ \\
\hline $\mathrm{H}$ & -15.6336 & $16.8189-2.4867$ \\
\hline $\mathrm{H}$ & -14.5943 & $16.8861-1.0588$ \\
\hline $\mathrm{H}$ & -17.0382 & $16.8103-0.3670$ \\
\hline $\mathrm{H}$ & -17.3538 & $18.2750-1.3061$ \\
\hline $\mathrm{H}$ & -16.3151 & $18.3430 \quad 0.1223$ \\
\hline
\end{tabular}




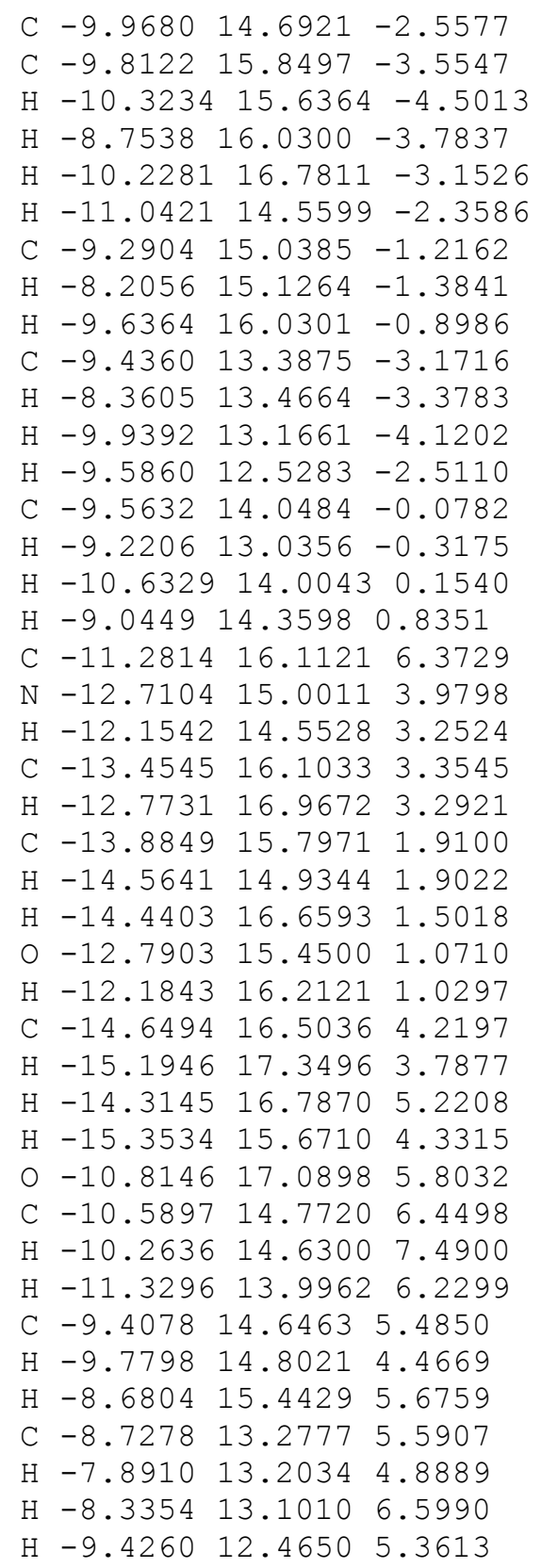

\section{$\underline{\text { TS for nitrogen inversion (the rate limiting TS) }}$}

The TS for nitrogen inversion has a "flat" $\mathrm{sp}^{2}$ like nitrogen and is concerted with amide bond synthesis at the B3LYP/6-31G(d,p) level. One imaginary frequency of $441.6 \mathrm{i} \mathrm{cm}^{-1}$ corresponded to nitrogen inversion and amide bond synthesis.

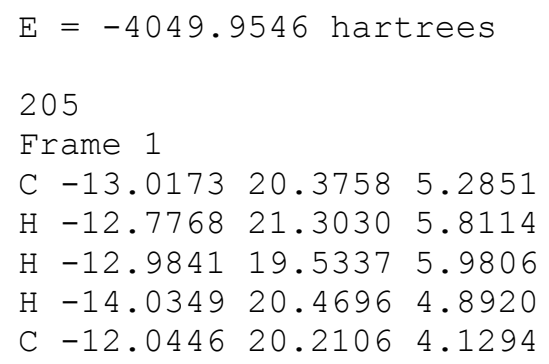




\begin{tabular}{|c|c|c|}
\hline 0 & $\begin{array}{lll}-11.7759 & 21.1493\end{array}$ & 3.3648 \\
\hline $\mathrm{N}$ & $\begin{array}{lll}-11.5151 & 18.9727\end{array}$ & 3.9926 \\
\hline $\mathrm{H}$ & $-11.6873 \quad 18.2690$ & 4.7187 \\
\hline $\mathrm{C}$ & -10.431618 .7168 & 3.0453 \\
\hline $\mathrm{H}$ & $\begin{array}{lll}-9.7799 & 19.5990\end{array}$ & 3.0563 \\
\hline C & $-10.9787 \quad 18.5471$ & 1.6036 \\
\hline O & $-11.2357 \quad 17.4447$ & 1.0996 \\
\hline C & $-9.6080 \quad 17.4824$ & 3.5000 \\
\hline $\mathrm{H}$ & $-10.2024 \quad 16.5845$ & 3.2867 \\
\hline $\mathrm{O}$ & $-9.3134 \quad 17.5693$ & 4.8820 \\
\hline $\mathrm{H}$ & -10.095617 .2125 & 5.3799 \\
\hline $\mathrm{C}$ & -8.288317 .3980 & 2.7371 \\
\hline $\mathrm{H}$ & $-8.4506 \quad 17.3511$ & 1.6562 \\
\hline $\mathrm{H}$ & $-7.7442 \quad 16.5012$ & 3.0457 \\
\hline $\mathrm{H}$ & -7.663518 .2682 & 2.9682 \\
\hline $\mathrm{N}$ & $-11.1071 \quad 19.7093$ & 0.9177 \\
\hline $\mathrm{H}$ & $\begin{array}{lll}-11.1510 & 20.5448\end{array}$ & 31.5013 \\
\hline C & $-11.6121 \quad 19.7519$ & -0.4490 \\
\hline $\mathrm{H}$ & -12.705619 .6742 & -0.4952 \\
\hline $\mathrm{H}$ & $\begin{array}{lll}-11.3013 & 20.6907\end{array}$ & -0.9142 \\
\hline $\mathrm{H}$ & -11.190618 .9136 & $5-1.0077$ \\
\hline $\mathrm{C}$ & -16.091718 .2533 & 10.0824 \\
\hline $\mathrm{H}$ & -15.685919 .0356 & 510.7377 \\
\hline $\mathrm{H}$ & $-17.0028 \quad 17.8763$ & 310.5537 \\
\hline C & $-15.0965 \quad 17.0904$ & 10.1036 \\
\hline 0 & $-15.3420 \quad 16.0530$ & 10.7213 \\
\hline C & $-16.4214 \quad 18.8729$ & 8.7155 \\
\hline $\mathrm{H}$ & $-17.0259 \quad 19.7735$ & 8.8959 \\
\hline $\mathrm{H}$ & $-15.5028 \quad 19.2484$ & 8.2379 \\
\hline C & $-17.1557 \quad 17.9716$ & 7.7644 \\
\hline $\mathrm{C}$ & -17.444916 .6332 & 7.8955 \\
\hline $\mathrm{H}$ & $\begin{array}{lll}-17.1951 & 15.9507\end{array}$ & 8.6960 \\
\hline $\mathrm{C}$ & $-17.7124 \quad 18.3809$ & 6.5012 \\
\hline $\mathrm{N}$ & $-18.1493 \quad 16.1841$ & 6.7956 \\
\hline $\mathrm{H}$ & -18.440515 .2182 & 6.6652 \\
\hline $\mathrm{C}$ & $-18.3256 \quad 17.2330$ & 5.9196 \\
\hline C & $-17.7535 \quad 19.6046$ & 5.8107 \\
\hline $\mathrm{H}$ & $-17.2926 \quad 20.4923$ & 36.2374 \\
\hline $\mathrm{C}$ & -18.963517 .2970 & 4.6746 \\
\hline $\mathrm{H}$ & -19.416516 .4173 & 4.2281 \\
\hline C & -18.388619 .6666 & 54.5760 \\
\hline $\mathrm{H}$ & -18.421620 .6068 & 4.0318 \\
\hline $\mathrm{C}$ & $\begin{array}{lll}-18.9870 & 18.5210\end{array}$ & 4.0136 \\
\hline $\mathrm{H}$ & $-19.4694 \quad 18.5936$ & 3.0423 \\
\hline $\mathrm{N}$ & $-13.9097 \quad 17.2998$ & 9.4729 \\
\hline $\mathrm{H}$ & -13.765318 .1265 & 8.9134 \\
\hline C & $-12.7967 \quad 16.3603$ & 9.6004 \\
\hline $\mathrm{H}$ & $\begin{array}{lll}-12.8931 & 15.9107\end{array}$ & 10.5927 \\
\hline $\mathrm{C}$ & $-11.4728 \quad 17.1506$ & 9.6808 \\
\hline 0 & -10.898917 .2751 & 10.7653 \\
\hline $\mathrm{C}$ & -12.903615 .1633 & 8.6232 \\
\hline $\mathrm{H}$ & $-13.7770 \quad 14.6092$ & 8.9912 \\
\hline $\mathrm{H}$ & $-12.0261 \quad 14.5223$ & 8.7799 \\
\hline 0 & $-13.1578 \quad 15.4086$ & 7.2475 \\
\hline $\mathrm{N}$ & $-11.0431 \quad 17.7245$ & 8.5352 \\
\hline $\mathrm{H}$ & $-11.3891 \quad 17.3892$ & 2.6073 \\
\hline $\mathrm{C}$ & $-9.7820 \quad 18.4492$ & 8.5283 \\
\hline $\mathrm{H}$ & -9.518318 .6755 & 7.4925 \\
\hline $\mathrm{H}$ & -9.858519 .3842 & 9.0962 \\
\hline $\mathrm{H}$ & $-8.9789 \quad 17.8579$ & 8.9840 \\
\hline C & $-16.5277 \quad 6.8991$ & 8.6004 \\
\hline
\end{tabular}




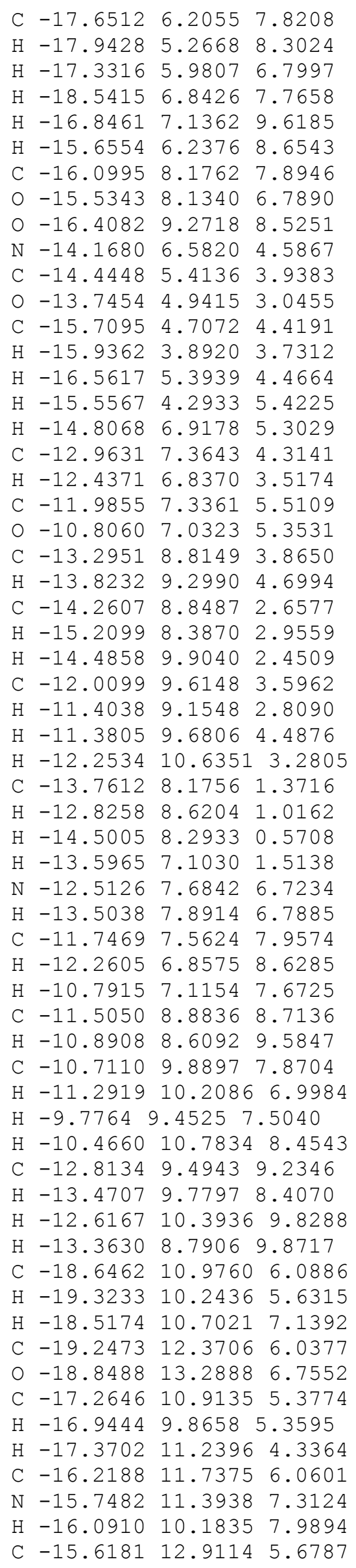




$$
\begin{aligned}
& \text { H }-15.7197 \quad 13.5037 \quad 4.7844 \\
& \text { C }-14.8948 \quad 12.3465 \quad 7.6683 \\
& \mathrm{H}-14.3464 \quad 12.3758 \quad 8.5969 \\
& \mathrm{~N}-14.7836 \quad 13.2834 \quad 6.7074 \\
& \mathrm{H}-14.1807 \quad 14.1443 \quad 6.7668 \\
& \mathrm{~N}-20.2406 \quad 12.5488 \quad 5.1205 \\
& \mathrm{H}-20.474611 .7851 \quad 4.5050 \\
& \text { C }-20.8406 \quad 13.84824 .8831 \\
& \mathrm{H}-20.3114 \quad 14.40994 .1040 \\
& \mathrm{H}-21.8827 \quad 13.7245 \quad 4.5753 \\
& \mathrm{H}-20.8079 \quad 14.4243 \quad 5.8093 \\
& \text { C }-19.7655 \quad 12.7442-0.7275 \\
& \text { C }-19.535914 .2562-0.6199 \\
& \mathrm{H}-20.449914 .8098-0.8636 \\
& \mathrm{H}-18.754214 .5877-1.3131 \\
& \begin{array}{llll}
\mathrm{H} & -19.2325 & 14.5567 & 0.3873
\end{array} \\
& \mathrm{H}-20.5408 \quad 12.4382-0.0086 \\
& \mathrm{H}-20.1734 \quad 12.5167-1.7221 \\
& \text { C }-18.510811 .8766-0.5032 \\
& \text { H }-17.7491 \quad 12.2020-1.2283 \\
& \text { C }-17.9209 \quad 12.0543 \quad 0.9041 \\
& \mathrm{H}-18.661711 .7911 \quad 1.6715 \\
& \text { H }-17.6008 \quad 13.08411 .0888 \\
& \mathrm{H}-17.047511 .40931 .0504 \\
& \text { C }-18.8208 \quad 10.3982-0.7802 \\
& \mathrm{H}-17.9249 \quad 9.7764-0.6771 \\
& \mathrm{H}-19.2141 \quad 10.2555-1.7932 \\
& \mathrm{H}-19.5720 \quad 10.0171-0.0763 \\
& \text { C }-16.370517 .6265-0.2381 \\
& \text { C }-15.176517 .5905-1.1957 \\
& \mathrm{H}-15.009918 .5690-1.6602 \\
& \mathrm{H}-15.335316 .8676-2.0046 \\
& \mathrm{H}-14.2550 \quad 17.3091-0.6759 \\
& \text { H }-16.5457 \quad 16.6450 \quad 0.2152 \\
& \mathrm{H}-17.291217 .9223-0.7541 \\
& \mathrm{H}-16.2057 \quad 18.3376 \quad 0.5781 \\
& \text { C }-9.8390 \quad 14.6792-2.6138 \\
& \text { C }-9.7624 \quad 15.8626-3.5917 \\
& \mathrm{H}-10.1677 \quad 15.5963-4.5752 \\
& \mathrm{H}-8.7226 \quad 16.1834 \quad-3.7378 \\
& \mathrm{H}-10.3275 \quad 16.7235-3.2182 \\
& \mathrm{H}-10.8982 \quad 14.3999-2.5044 \\
& \text { C }-9.320915 .0855-1.2187 \\
& \mathrm{H}-8.2473 \quad 15.3161-1.2997 \\
& \mathrm{H}-9.8144 \quad 16.0174-0.9137 \\
& \text { C }-9.088713 .4669-3.1875 \\
& \mathrm{H}-8.0203 \quad 13.6921-3.3040 \\
& \mathrm{H}-9.4774 \quad 13.1909-4.1751 \\
& \mathrm{H}-9.1734 \quad 12.5870 \quad-2.5427 \\
& \text { C }-9.545014 .0451-0.1147 \\
& \mathrm{H}-9.0604 \quad 13.0887-0.3424 \\
& \mathrm{H}-10.6122 \quad 13.8590 \quad 0.0471 \\
& \mathrm{H}-9.1377 \quad 14.39910 .8376 \\
& \text { C }-12.0033 \quad 15.5377 \quad 6.1374 \\
& \mathrm{~N}-12.6287 \quad 15.0642 \quad 4.9179 \\
& \mathrm{H}-12.5263 \quad 14.0987 \quad 4.6479 \\
& \text { C }-13.3603 \quad 15.9797 \quad 4.0523 \\
& \mathrm{H}-12.733916 .85413 .8610 \\
& \text { C }-13.5790 \quad 15.3123 \quad 2.6849 \\
& \text { H }-14.1566 \quad 14.38412 .8157 \\
& \text { H }-14.194915 .98552 .0660
\end{aligned}
$$




$\begin{array}{llll}\mathrm{O} & -12.3804 & 14.9444 & 2.0262 \\ \mathrm{H} & -11.9281 & 15.7646 & 1.7529 \\ \mathrm{C} & -14.6843 & 16.4901 & 4.6418 \\ \mathrm{H} & -15.1030 & 17.2952 & 4.0257 \\ \mathrm{H} & -14.5222 & 16.8703 & 5.6519 \\ \mathrm{H} & -15.4400 & 15.6986 & 4.7093 \\ \mathrm{O}-11.6290 & 16.8125 & 6.0745 \\ \mathrm{C} & -10.9053 & 14.5214 & 6.5528 \\ \mathrm{H} & -10.4314 & 14.8786 & 7.4732 \\ \mathrm{H} & -11.3806 & 13.5575 & 6.7881 \\ \mathrm{C} & -9.8114 & 14.2923 & 5.4973 \\ \mathrm{H} & -10.2737 & 14.0401 & 4.5360 \\ \mathrm{H} & -9.2613 & 15.2247 & 5.3384 \\ \mathrm{C} & -8.8306 & 13.1842 & 5.8989 \\ \mathrm{H} & -8.0597 & 13.0457 & 5.1326 \\ \mathrm{H} & -8.3224 & 13.4195 & 6.8420 \\ \mathrm{H} & -9.3411 & 12.2223 & 6.0310\end{array}$




\section{Proton shuttle mechanism of O-acylation:}

\section{ES-complex for the proton shuttle mechanism of $O$-acylation}

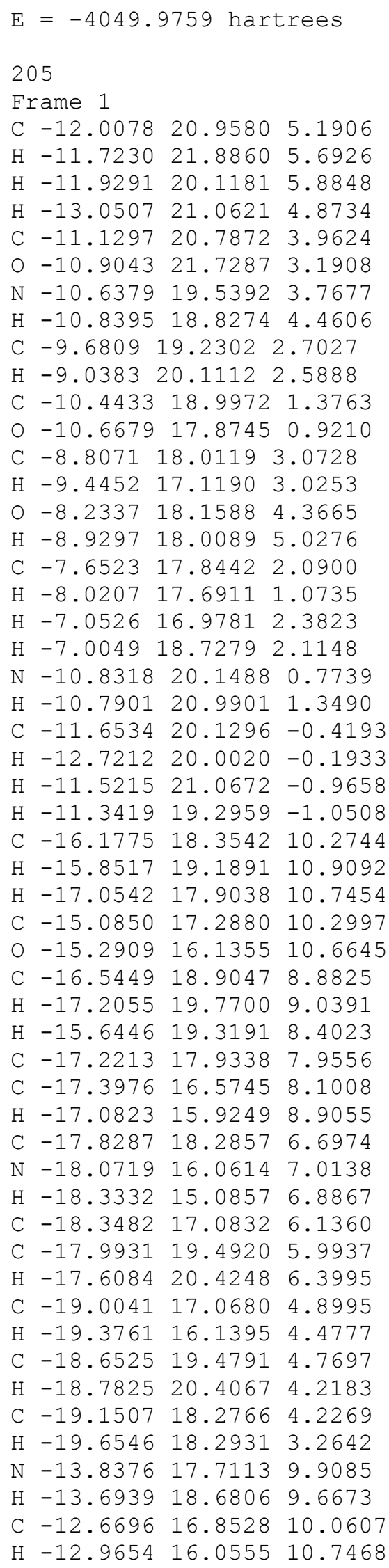




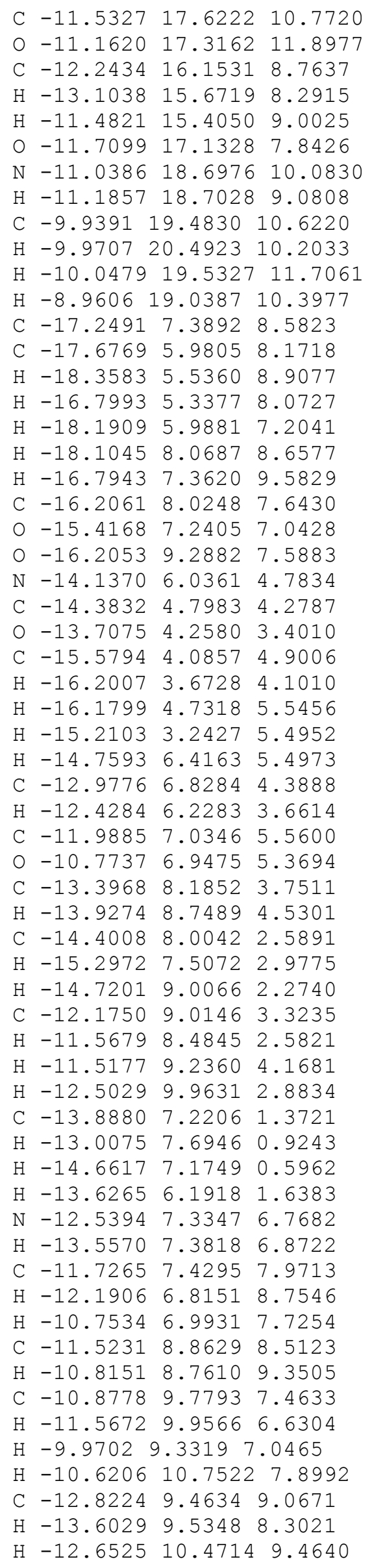



$\mathrm{H}-13.2247 \quad 8.85179 .8837$
C $-18.9139 \quad 10.9034 \quad 6.2987$
$\mathrm{H}-19.7528 \quad 10.2630 \quad 6.6023$
$\mathrm{H}-18.2025 \quad 10.9334 \quad 7.1257$
C -19.440512 .31196 .0582$
$\begin{array}{llll}0 & -18.9948 & 13.3069 & 6.6285\end{array}$
C $-18.2275 \quad 10.2730 \quad 5.0574$
$\mathrm{H}-18.0403 \quad 9.2191 \quad 5.2897$
H $-18.9041 \quad 10.2866 \quad 4.1939$
C -16.942010 .93554 .6710$
$\mathrm{N}-15.7998 \quad 10.7867 \quad 5.4263$
$\mathrm{H}-15.7486 \quad 10.1810 \quad 6.2850$
C $-16.5887 \quad 11.7703 \quad 3.6329$
H $-17.2117 \quad 12.1271 \quad 2.8234$
C $-14.830611 .5188 \quad 4.8305$
$\mathrm{H}-13.8244 \quad 11.5823 \quad 5.2208$
$\mathrm{N}-15.2622 \quad 12.1302 \quad 3.7356$
$\mathrm{H}-12.9094 \quad 14.9418 \quad 5.1072$
$\mathrm{N}-20.4781 \quad 12.3870 \quad 5.1712$
$\mathrm{H}-20.7561 \quad 11.5417 \quad 4.6965$
C $-21.0980 \quad 13.6360 \quad 4.7740$
$\mathrm{H}-20.694914 .01893 .8265$
$\mathrm{H}-22.1786 \quad 13.5022 \quad 4.6633$
$\mathrm{H}-20.9093 \quad 14.3727 \quad 5.5551$
C $-20.123312 .8301-0.9675$
C $-19.5972 \quad 14.2326-0.6389$
$\mathrm{H}-20.4236 \quad 14.9287-0.4572$
$\mathrm{H}-19.001214 .6360-1.4656$
$\mathrm{H}-18.9657 \quad 14.2358 \quad 0.2556$
$\mathrm{H}-20.7094 \quad 12.4494-0.1177$
$\mathrm{H}-20.8269 \quad 12.9039-1.8087$
C $-19.039211 .7923-1.3226$
$\mathrm{H}-18.4541 \quad 12.1991-2.1622$
C $-18.073811 .5338-0.1566$
H $-18.6136 \quad 11.1484 \quad 0.7178$
$\mathrm{H}-17.5448 \quad 12.4410 \quad 0.1503$
$\mathrm{H}-17.3153 \quad 10.7908-0.4248$
C $-19.6836 \quad 10.4791-1.7913$
$\mathrm{H}-18.9249 \quad 9.7440-2.0811$
$\mathrm{H}-20.3441 \quad 10.6396-2.6513$
$\mathrm{H}-20.2857 \quad 10.0323-0.9897$
C $-16.6021 \quad 17.5050-0.6049$
C $-15.2107 \quad 17.5496-1.2397$
$\mathrm{H}-15.0072 \quad 18.5328-1.6814$
$\mathrm{H}-15.1166 \quad 16.8088-2.0419$
$\mathrm{H}-14.4240 \quad 17.3452-0.5087$
$\mathrm{H}-16.813416 .5197-0.1768$
$\mathrm{H}-17.3858 \quad 17.7199-1.3399$
H -16.696518 .23850 .2028$
C $-9.818914 .7027-2.5376$
C $-9.8394 \quad 15.8793-3.5235$
$\mathrm{H}-10.2827 \quad 15.5908-4.4837$
$\mathrm{H}-8.821916 .2398-3.7223$
H $-10.4167 \quad 16.7215-3.1257$
$\mathrm{H}-10.8594 \quad 14.3803-2.3764$
C $-9.255615 .1524-1.1750$
$\mathrm{H}-8.2136 \quad 15.4782-1.3168$
$\mathrm{H}-9.808716 .0371-0.8354$
C $-9.048313 .5167-3.1375$
$\mathrm{H}-7.9944 \quad 13.7795-3.2978$
$\mathrm{H}-9.4668 \quad 13.2247-4.1080$ 


$\begin{array}{llll}\text { H } & -9.0769 & 12.6357 & -2.4892 \\ \mathrm{C} & -9.3112 & 14.0905 & -0.0710 \\ \mathrm{H} & -8.6719 & 13.2288 & -0.2893 \\ \mathrm{H} & -10.3336 & 13.7185 & 0.0674 \\ \mathrm{H} & -8.9832 & 14.5115 & 0.8851 \\ \mathrm{C} & -10.9049 & 16.7994 & 6.8140 \\ \mathrm{O} & -13.0857 & 15.8246 & 5.5167 \\ \mathrm{H} & -12.6253 & 14.4121 & 2.6115 \\ \mathrm{C} & -13.5488 & 16.5445 & 4.3826 \\ \mathrm{H} & -12.7174 & 17.0833 & 3.8934 \\ \mathrm{C} & -14.1728 & 15.5470 & 3.3819 \\ \mathrm{H} & -15.1312 & 15.2171 & 3.8004 \\ \mathrm{C} & -14.3985 & 16.1795 & 2.0105 \\ \mathrm{~N}-13.3112 & 14.3528 & 3.3610 \\ \mathrm{H}-13.8891 & 13.5136 & 3.2337 \\ \mathrm{H} & -14.2871 & 17.2882 & 4.7051 \\ \mathrm{H} & -15.0453 & 17.0625 & 2.0776 \\ \mathrm{H} & -13.4441 & 16.4949 & 1.5693 \\ \mathrm{H} & -14.8737 & 15.4661 & 1.3292 \\ \mathrm{O} & -10.5334 & 17.7194 & 6.0977 \\ \mathrm{C} & -10.4072 & 15.3763 & 6.6872 \\ \mathrm{H} & -9.6760 & 15.2155 & 7.4952 \\ \mathrm{H} & -11.2332 & 14.6869 & 6.8786 \\ \mathrm{C} & -9.7675 & 15.0743 & 5.3283 \\ \mathrm{H} & -10.5032 & 15.2967 & 4.5486 \\ \mathrm{H} & -8.9159 & 15.7425 & 5.1636 \\ \mathrm{C} & -9.3242 & 13.6133 & 5.2135 \\ \mathrm{H} & -8.8653 & 13.4231 & 4.2383 \\ \mathrm{H} & -8.5896 & 13.3509 & 5.9837 \\ \mathrm{H} & -10.1739 & 12.9291 & 5.3155\end{array}$


TS model for the proton shuttle mechanism of $O$-acylation

\section{Using constrained distances, see Figure S12.}

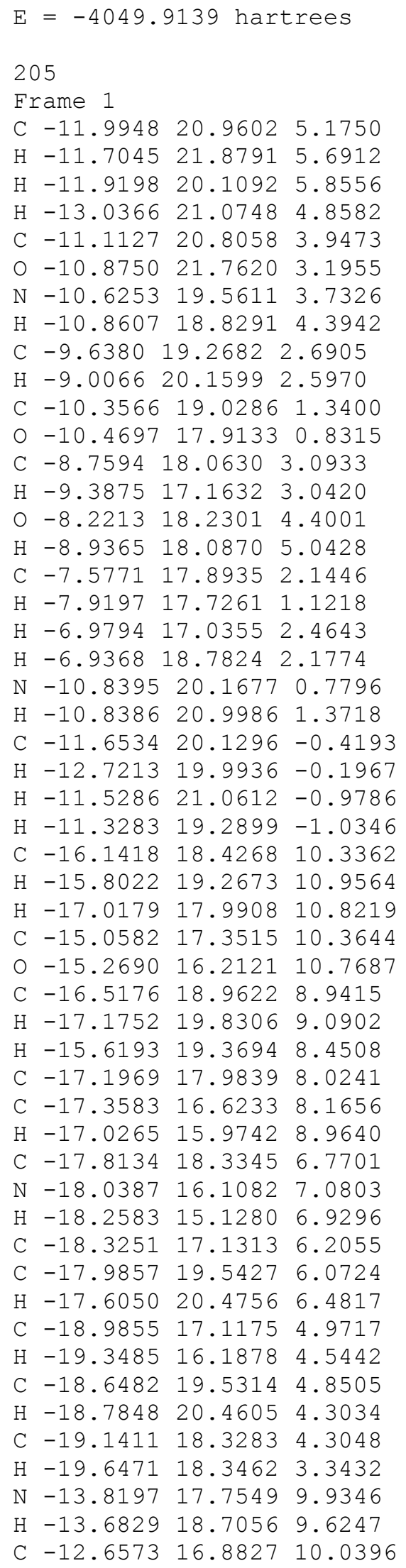



$\mathrm{H}-12.9490 \quad 16.0767 \quad 10.7165$
C $-11.5067 \quad 17.6308 \quad 10.7552$
O $-11.159617 .3276 \quad 11.8900$
C $-12.2683 \quad 16.2086 \quad 8.7177$
$\mathrm{H}-13.1416 \quad 15.7455 \quad 8.2505$
$\mathrm{H}-11.5127 \quad 15.4465 \quad 8.9286$
$0-11.7413 \quad 17.1972 \quad 7.8071$
$\mathrm{N}-10.979618 .6883 \quad 10.0653$
$\mathrm{H}-11.1231 \quad 18.69819 .0623$
C -9.884919 .468910 .6195$
$\mathrm{H}-9.9097 \quad 20.4808 \quad 10.2062$
$\mathrm{H}-10.0054 \quad 19.5128 \quad 11.7027$
$\mathrm{H}-8.9042 \quad 19.0251 \quad 10.4033$
C $-17.2707 \quad 7.41338 .5283$
C $-17.67695 .9805 \quad 8.1718$
$\mathrm{H}-18.32195 .5464 \quad 8.9448$
$\mathrm{H}-16.7874 \quad 5.3556 \quad 8.0657$
$\mathrm{H}-18.2228 \quad 5.9473 \quad 7.2229$
$\mathrm{H}-18.1406 \quad 8.07198 .6173$
$\mathrm{H}-16.7780 \quad 7.42479 .5110$
C -16.28018 .04237 .5339$
O $-15.4575 \quad 7.2784 \quad 6.9653$
o $-16.3543 \quad 9.3044 \quad 7.3957$
$\mathrm{N}-14.1174 \quad 6.0474 \quad 4.7637$
C -14.36094 .80614 .2639$
$\begin{array}{lllll}0 & -13.6793 & 4.2624 & 3.3944\end{array}$
C $-15.5620 \quad 4.09974 .8835$
$\mathrm{H}-16.19173 .7007 \quad 4.0835$
$\mathrm{H}-16.15324 .7458 \quad 5.5372$
$\mathrm{H}-15.19913 .24765 .4685$
$\mathrm{H}-14.74916 .4325 \quad 5.4649$
C $-12.9524 \quad 6.83654 .3817$
$\mathrm{H}-12.4030 \quad 6.2429 \quad 3.6493$
C $-11.9700 \quad 7.02775 .5595$
O $-10.7556 \quad 6.9283 \quad 5.3823$
C $-13.3617 \quad 8.2046 \quad 3.7637$
H $-13.8837 \quad 8.7582 \quad 4.5564$
C $-14.3737 \quad 8.04552 .6059$
$\mathrm{H}-15.2758 \quad 7.5595 \quad 2.9954$
H $-14.6787 \quad 9.0537 \quad 2.2931$
C $-12.1340 \quad 9.0294 \quad 3.3441$
$\mathrm{H}-11.5309 \quad 8.50112 .5987$
$\mathrm{H}-11.47559 .2396 \quad 4.1904$
$\mathrm{H}-12.4496 \quad 9.9850 \quad 2.9101$
C $-13.8761 \quad 7.2611 \quad 1.3837$
$\mathrm{H}-12.9908 \quad 7.72560 .9366$
$\mathrm{H}-14.6527 \quad 7.22940 .6105$
$\mathrm{H}-13.6276 \quad 6.2278 \quad 1.6446$
$\mathrm{N}-12.5295 \quad 7.33916 .7621$
$\mathrm{H}-13.5447 \quad 7.3851 \quad 6.8555$
C -11.72657 .42957 .9713$
$\mathrm{H}-12.19696 .8126 \quad 8.7498$
$\mathrm{H}-10.7530 \quad 6.9929 \quad 7.7323$
C $-11.52548 .8606 \quad 8.5204$
$\mathrm{H}-10.8345 \quad 8.7508 \quad 9.3715$
C $-10.85579 .7783 \quad 7.4885$
$\mathrm{H}-11.5285 \quad 9.9685 \quad 6.6450$
$\mathrm{H}-9.9445 \quad 9.3269 \quad 7.0842$
$\mathrm{H}-10.5978 \quad 10.7459 \quad 7.9343$
C $-12.83019 .4682 \quad 9.0549$
$\mathrm{H}-13.59199 .5517 \quad 8.2718$ 

H $-12.6602 \quad 10.4730 \quad 9.4592$
$\mathrm{H}-13.2546 \quad 8.8562 \quad 9.8599$
C $-18.9342 \quad 10.83576 .1509$
$\mathrm{H}-19.7789 \quad 10.19356 .4310$
$\mathrm{H}-18.2066 \quad 10.7993 \quad 6.9631$
C $-19.4258 \quad 12.2649 \quad 5.9749$
O $-18.879513 .2426 \quad 6.4811$
C $-18.2924 \quad 10.2742 \quad 4.8524$
$\mathrm{H}-18.12239 .2023 \quad 4.9986$
$\mathrm{H}-18.9797 \quad 10.3749 \quad 4.0054$
C $-16.992910 .9334 \quad 4.5091$
$\mathrm{N}-15.8798 \quad 10.7209 \quad 5.2996$
$\mathrm{H}-15.8921 \quad 10.08426 .1803$
C $-16.6151 \quad 11.8184 \quad 3.5260$
$\mathrm{H}-17.1862 \quad 12.2400 \quad 2.7147$
C $-14.883311 .4584 \quad 4.8117$
$\mathrm{H}-13.895911 .5579 \quad 5.2338$
$\mathrm{N}-15.2858 \quad 12.1247 \quad 3.7261$
$\mathrm{H}-12.8699 \quad 14.7995 \quad 4.9321$
$\mathrm{N}-20.533212 .3693 \quad 5.1808$
$\mathrm{H}-20.897311 .5266 \quad 4.7631$
C $-21.0980 \quad 13.6360 \quad 4.7740$
$\mathrm{H}-20.7008 \quad 13.9834 \quad 3.8104$
$\mathrm{H}-22.1857 \quad 13.5558 \quad 4.6941$
$\mathrm{H}-20.8545 \quad 14.3816 \quad 5.5332$
C $-20.1258 \quad 12.8245-0.9309$
C $-19.5972 \quad 14.2326-0.6389$
$\mathrm{H}-20.421614 .9335-0.4640$
$\mathrm{H}-19.0078 \quad 14.6184-1.4780$
$\mathrm{H}-18.9586 \quad 14.2580 \quad 0.2501$
$\mathrm{H}-20.7043 \quad 12.4613-0.0680$
$\mathrm{H}-20.8360 \quad 12.8800-1.7675$
C $-19.0427 \quad 11.7821-1.2731$
$\mathrm{H}-18.4625 \quad 12.1742-2.1224$
C $-18.069711 .5495-0.1079$
$\mathrm{H}-18.606911 .18310 .7769$
$\mathrm{H}-17.5405 \quad 12.4657 \quad 0.1723$
$\mathrm{H}-17.3123 \quad 10.8010-0.3638$
C $-19.687210 .4591-1.7118$
$\mathrm{H}-18.9296 \quad 9.7198-1.9933$
$\mathrm{H}-20.3532 \quad 10.6036-2.5702$
$\mathrm{H}-20.2842 \quad 10.0272-0.8983$
C $-16.5873 \quad 17.5509-0.5707$
C $-15.2107 \quad 17.5496-1.2397$
$\mathrm{H}-14.9790 \quad 18.5305-1.6722$
$\mathrm{H}-15.1600 \quad 16.8143-2.0500$
$\mathrm{H}-14.4204 \quad 17.3084-0.5230$
$\mathrm{H}-16.8183 \quad 16.5717-0.1387$
$\mathrm{H}-17.382517 .7966-1.2843$
$\mathrm{H}-16.6352 \quad 18.2830 \quad 0.2427$
C $-9.816814 .7226-2.5139$
C $-9.8394 \quad 15.8793-3.5235$
$\mathrm{H}-10.2866 \quad 15.5728-4.4772$
$\mathrm{H}-8.8207 \quad 16.2331-3.7341$
$\mathrm{H}-10.4108 \quad 16.7309-3.1399$
$\mathrm{H}-10.8580 \quad 14.4087-2.3407$
C $-9.243615 .1938-1.1627$
$\mathrm{H}-8.197815 .5033-1.3143$
$\mathrm{H}-9.782916 .0915-0.8376$
C $-9.055213 .5203-3.0930$
$\mathrm{H}-7.999913 .7735-3.2604$ 


$\begin{array}{llll}\text { H } & -9.4778 & 13.2104 & -4.0563 \\ \text { H } & -9.0868 & 12.6534 & -2.4259 \\ \mathrm{C} & -9.3085 & 14.1567 & -0.0355 \\ \mathrm{H} & -8.6795 & 13.2822 & -0.2343 \\ \mathrm{H} & -10.3349 & 13.8019 & 0.1162 \\ \mathrm{H} & -8.9744 & 14.5967 & 0.9097 \\ \mathrm{C} & -10.9512 & 16.8616 & 6.7610 \\ \mathrm{O} & -13.0651 & 15.8640 & 5.4023 \\ \mathrm{H} & -12.7187 & 14.0233 & 2.9809 \\ \mathrm{C} & -13.6649 & 16.4141 & 4.2637 \\ \mathrm{H} & -12.9296 & 16.9574 & 3.6318 \\ \mathrm{C} & -14.2737 & 15.2312 & 3.4390 \\ \mathrm{H} & -15.2743 & 15.0410 & 3.8653 \\ \mathrm{C} & -14.4437 & 15.6218 & 1.9707 \\ \mathrm{~N} & -13.4709 & 14.0261 & 3.6783 \\ \mathrm{H} & -14.5535 & 12.8642 & 3.4376 \\ \mathrm{H} & -14.4483 & 17.1356 & 4.5430 \\ \mathrm{H} & -15.0405 & 16.5382 & 1.8693 \\ \mathrm{H} & -13.4647 & 15.8112 & 1.5104 \\ \mathrm{H} & -14.9384 & 14.8314 & 1.3926 \\ \mathrm{O} & -10.5536 & 17.7904 & 6.0714 \\ \mathrm{C} & -10.4690 & 15.4348 & 6.6337 \\ \mathrm{H} & -9.7674 & 15.2573 & 7.4653 \\ \mathrm{H} & -11.3157 & 14.7612 & 6.7817 \\ \mathrm{C} & -9.7876 & 15.1352 & 5.2973 \\ \mathrm{H} & -10.5093 & 15.3466 & 4.5024 \\ \mathrm{H} & -8.9362 & 15.8089 & 5.1537 \\ \mathrm{C} & -9.3285 & 13.6773 & 5.2065 \\ \mathrm{H} & -8.8422 & 13.4807 & 4.2459 \\ \mathrm{H} & -8.6117 & 13.4286 & 5.9988 \\ \mathrm{H} & -10.1768 & 12.9892 & 5.2937\end{array}$




\section{Shockwave Flash movies}

\section{Reaction path for the proton shuttle of $N$-acylation}

\section{alaninol_protonshuttle_large_B3LYP_631Gdp.swf}

This movie shows the reaction path for the proton shuttle mechanism of $N$-acylation of $(R)$ alaninol in the large active site model of Candida antarctica lipase B consisting of 205 atoms.

\section{$\underline{\text { Nitrogen inversion }}$}

\section{Small active site model}

\section{NMe_inversion_small_MP2_631Gdp.swf}

This movie shows the reaction path for nitrogen inversion for methyl amine in the small serine hydrolase active site model using MP2/6-31G(d,p) level of theory. The reaction path goes through the $\mathrm{sp}^{2}$ like transition state for nitrogen inversion, which is a separate TS from amide bond synthesis at this level of theory.

\section{NMe_inversion_small_B3LYP_631Gdp.swf}

This movie shows the computed IRC for methyl amine in the small active site model using B3LYP/6-31G(d,p) level of theory. Amide bond synthesis is concerted with nitrogen inversion at this level of theory.

\section{Large active site model}

The reaction paths were calculated in the large active site model consisting of 205 atoms.

\section{alaninol_inversion_large_HF_631Gdp.swf}

This movie shows the reaction path for nitrogen inversion for $(R)$-alaninol in the large active site model using HF/6-31G(d,p) level of theory. The reaction path goes through the $\mathrm{sp}^{2}$ like transition state for nitrogen inversion, which is a separate TS from amide bond synthesis at this level of theory. The transition state for nitrogen inversion breaks the hydrogen bond between the catalytic His $\mathrm{N}_{\varepsilon 2}$ and the scissile nitrogen atom which causes the catalytic base to move towards S105.

\section{alaninol_inversion_large_B3LYP_631Gdp.swf}

This movie shows the reaction path for nitrogen inversion for $(R)$-alaninol in the large active site model using B3LYP/6-31G(d,p) level of theory. Only the first 18 points of the reaction path are shown for each direction. The movie shows how nitrogen inversion is concerted with amide bond synthesis at this level of theory and how the catalytic base (H224) moves towards S105. 


\section{Supplementary references}

[1] a) T. D. Smith, J. B. Gerken, P. V. Jog, J. D. Roberts, Org. Lett. 2007, 9, 4555-4557; b) P. Butz, R. T. Kroemer, N. A. Macleod, E. G. Robertson, J. P. Simons, J. Phys. Chem. A 2001, 105, 10501056.

[2] P. Deslongchamps, Tetrahedron 1975, 31, 2463-2490.

[3] P.-O. Syren, K. Hult, ChemCatChem 2011, 3, 853-860.

[4] a) H. K. Hall, Jr., J. Am. Chem. Soc. 1957, 79, 5441-5444; b) V. S. Bryantsev, M. S. Diallo, W. A. Goddard, III, J. Phys. Chem. A 2007, 111, 4422-4430; c) F. Khalili, A. Henni, A. L. L. East, J. Mol. Struct.: THEOCHEM 2009, 916, 1-9. 